\title{
SCIENCE SKETCHES
}




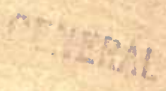




\section{SCIENCE SKETCHES}

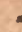







SCIENCE SKETCHES 



\section{SCIENCE SKETCHES}

BY

DAVID STARR JORDAN

New and Eenlarged Eeditín

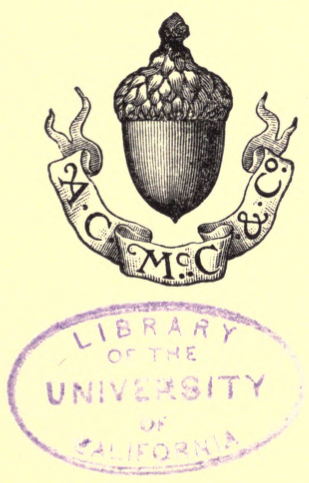

C H I C A GO

A. C. MCCLURG AND COMPANY

r 899 


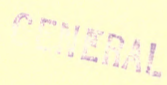

COPYRIGHT

By A. C. McClung and Co.

A. D. 1887 .

COPYRIGHT

By A. C. McClurg and Co.

A. D. 1896 . 
TO

ftly ftlother,

HULDAH HAWLEY JORDAN.

구 



\section{P R E F A C E.}

THIS volume is made up of sketches 1 reprinted from various periodicals, and coming under the general head of popular science. Most of these articles have been freely retouched since their original appearance. The volume corresponds in part to the first edition of "Science Sketches," published in 1887. Eight of the articles are the same, being printed from the same plates, with a few verbal changes. For certain others of the first edition, - the accounts of "Agassiz at Penikese," "The Fate of Iciodorum," "The Story of a Strange Land," and "How the Trout came to California," articles written since 1887 have been substituted. The author wishes to express his especial obligations to Messrs. D. Appleton 
\& Company for permission to reprint the six articles which have appeared in the "Popular Science Monthly." $\mathrm{He}$ is also indebted for similar permission to the publishers of the "American Naturalist," "St. Nicholas," "Recreation," and the "Riverside Natural History," from each of which publications one article has been taken.

Leland Stanford JR. University,

Palo Alto, Cal., April 30, 1896. 


\section{CON TEN TS.}

Chapter

I. The Story of a Salimon • • . . . . 9

II. JohnNy DaRTers • • • • • . • • 20

III. The Salmon Family . . . . . . . . 35

IV. The Dispersion of Fresh-Water Fishes 83

V. Agassiz at Penikese • • • • • • . 133

VI. An Eccentric Naturalist. . : . . 153

Vil. A Cuban Fisherman . . . . . . . . 170

ViII. The Fate of Iciodorum . . . . . . I $\mathbf{I} \mathbf{I}$

IX. The Story of a Stone . . . . . . 224

X. An Ascent of the Matterhorn . • 232

XI. The Story of a Strange Land . . . 256

- XiI. How the Trout came to California . 267 



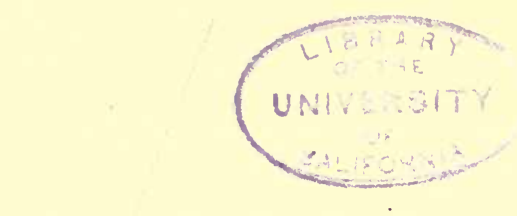

\section{SCIENCE SKETCHES.}

\section{THE STORY OF A SALMON.}

$\mathrm{N}$ the realm of the Northwest Wind, on the 1 boundary-line between the dark fir-forests and the sunny plains, there stands a mountain, - a great white cone two miles and a half in perpendicular height. On its lower mile the dense firwoods cover it with never-changing green; on its next half-mile a lighter green of grass and bushes gives place in winter to white; and on its uppermost mile the snows of the great ice age still linger in unspotted purity. The people of Washington Territory say that their mountain is the great "King-pin of the Universe," which shows that even in its own country Mount Tacoma is not without honor.

Flowing down from the southwest slope of Mount Tacoma is a cold, clear river, fed by the melting snows of the mountain. Madly it hastens down over white cascades and beds of shining sands, through birch-woods and belts of dark firs, to mingle its waters at last with those of the great Columbia. This river is the Cowlitz; and on its bottom, not many years ago, there lay half buried 
in the sand a number of little orange-colored globules, each about as large as a pea. These were not much in themselves, but great in their possibilities. In the waters above them little suckers and chubs and prickly sculpins strained their mouths to draw these globules from the sand, and vicious-looking crawfishes picked them up with their blundering hands and examined them with their telescopic eyes. But one, at least, of the globules escaped their curiosity, else this story would not be worth telling. The sun shone down on it through the clear water, and the ripples of the Cowlitz said over it their incantations, and in it at last awoke a living being. It was a fish, - a curious little fellow, not half an inch long, with great, staring eyes, which made almost half his length, and with a body so transparent that he could not cast a shadow. He was a little salmon, a very little salmon; but the water was good, and there were flies and worms and little living creatures in abundance for him to eat, and he soon became a larger salmon. Then there were many more little salmon with him, some larger and some smaller, and they all had a merry time. Those who had been born soonest and had grown largest used to chase the others around and bite off their tails, or, still better, take them by the heads and swallow them whole; for, said they, " even young salmon are good eating." "Heads I win, tails you lose," was their motto. Thus, what was once two small salmon became united into a single larger one, and the process of "addition, division, and silence" still went on. 
By-and-by, when all the salmon were too large to be swallowed, they began to grow restless. They saw that the water rushing by seemed to be in a great hurry to get somewhere, and it was somehow suggested that its hurry was caused by something good to eat at the other end of its course. Then they all started down the stream, salmon-fashion, - which fashion is to get into the current, head up-stream, and thus to drift backward as the river sweeps along.

Down the Cowlitz River the salmon went for a day and a night, finding much to interest them which we need not know. At last they began to grow hungry; and coming near the shore, they saw an angle-worm of rare size and beauty floating in an eddy of the stream. Quick as thought one of them opened his mouth, which was well filled with teeth of different sizes, and put it around the angleworm. Quicker still he felt a sharp pain in his gills, followed by a smothering sensation, and in an instant his comrades saw him rise straight into the air. This was nothing new to them; for they often leaped out of the water in their games of hide-and-seek, but only to come down again with a loud splash not far from where they went out. But this one never came back, and the others went on their course wondering.

At last they came to where the Cowlitz and the Columbia join, and they were almost lost for a time; for they could find no shores, and the bottom and the top of the water were so far apart. Here they saw other and far larger salmon in the deepest part of the current, turning neither to the right nor 
to the left, but swimming right on up-stream just as rapidly as they could. And these great salmon would not stop for them, and would not lie and float with the current. They had no time to talk, even in the simple sign-language by which fishes express their ideas, and no time to eat. They had important work before them, and the time was short. So they went on up the river, keeping their great purposes to themselves; and our little salmon and his friends from the Cowlitz drifted down the stream.

By-and-by the water began to change. It grew denser, and no longer flowed rapidly along; and twice a day it used to turn about and flow the other way. Then the shores disappeared, and the water began to have a different and peculiar flavor, - a flavor which seemed to the salmon much richer and more inspiring than the glacier-water of their native Cowlitz. There were many curious things to see, - crabs with hard shells and savage faces, but so good when crushed and swallowed! Then there were luscious squid swimming about; and, to a salmon, squid are like ripe peaches and cream. There were great companies of delicate sardines and herring, green and silvery, and it was such fun to chase and capture them! Those who eat sardines packed in oil by greasy fingers, and herrings dried in the smoke, can have little idea how satisfying it is to have a meal of them, plump and sleek and silvery, fresh from the sea.

Thus the salmon chased the herrings about, and had a merry time. Then they were chased about in turn by great sea-lions, - swimming monsters 
with huge half-human faces, long thin whiskers, and blundering ways. The sea-lions liked to bite out the throat of a salmon, with its precious stomach full of luscious sardines, and then to leave the rest of the fish to shift for itself. And the seals and the herrings scattered the salmon about, till at last the hero of our story found himself quite alone, with none of his own kind near him. But that did not trouble him much, and he went on his own way, getting his dinner when he was hungry, which was all the time, and then eating a little between meals for his stomach's sake.

So it went on for three long years; and at the end of this time our little fish had grown to be a great, fine salmon of twenty-two pounds' weight, shining like a new tin pan, and with rows of the loveliest round black spots on his head and back and tail. One day, as he was swimming about, idly chasing a big sculpin with a head so thorny that he never was swallowed by anybody, all of a sudden the salmon noticed a change in the water around him.

Spring had come again, and the south-lying snow-drifts on the Cascade Mountains once more felt that the "earth was wheeling sunwards." The cold snow waters ran down from the mountains and into the Columbia River, and made a freshet on the river. The high water went far out into the sea, and out in the sea our salmon felt it on his gills. $\mathrm{He}$ remembered how the cold water used to feel in the Cowlitz when he was a little fish. In a blundering, fishy fashion he thought about it; he wondered whether the little eddy looked as it used 
to look, and whether caddis-worms and young mosquitoes were really as sweet and tender as he used to think they were. Then he thought some other things; but as the salmon's mind is located in the optic lobes of his brain, and ours is in a different place, we cannot be quite certain what his thoughts really were.

What our salmon did, we know. He did what every grown salmon in the ocean does when he feels the glacier-water once more upon his gills. He became a changed being. He spurned the blandishment of soft-shelled crabs. The pleasures of the table and of the chase, heretofore his only delights, lost their charms for him. He turned his course straight toward the direction whence the cold water came, and for the rest of his life never tasted a mouthful of food. He moved on toward the river-mouth, at first playfully, as though he were not really certain whether he meant anything after all. Afterward, when he struck the full current of the Columbia, he plunged straightforward with an unflinching determination that had in it something of the heroic. When he had passed the rough water at the bar, he was not alone. His old neighbors of the Cowlitz, and many more from the Clackamas and the Spokan and Des Chûtes and Kootanie, - a great army of salmon, - were with him. In front were thousands pressing on, and behind them were thousands more, all moved by a common impulse which urged them up the Columbia.

They were all swimming bravely along where the current was deepest, when suddenly the foremost 
felt something tickling like a cobweb about their noses and under their chins. They changed their course a little to brush it off, and it touched their fins as well. Then they tricd to slip down with the current, and thus leave it behind. But, no! the thing, whatever it was, although its touch was soft, refused to let go, and held them like a fetter. The more they struggled, the tighter became its grasp, and the whole foremost rank of the salmon felt it together; for it was a great gill-net, a quarter of a mile long, stretched squarely across the mouth of the river.

By-and-by men came in boats, and hauled up the gill-net and the helpless salmon that had become entangled in it. They threw the fishes into a pile in the bottom of the boat, and the others saw them no more. We that live outside the water know better what befalls them, and we can tell the story which the salmon could not.

All along the banks of the Columbia River, from its mouth to nearly thirty miles away, there is a succession of large buildings, looking like great barns or warehouses, built on piles in the river, high enough to be out of the reach of floods. There are thirty of these buildings, and they are called canneries. Each cannery has about forty boats, and with each boat are two men and a long gill-net. These nets fill the whole river as with a nest of cobwebs from April to July, and to each cannery nearly a thousand great salmon are brought every day. These salmon are thrown in a pile on the floor; and Wing Hop, the big Chinaman, takes them one after another on the table, and with 
a great knife dexterously cuts off the head, the tail, and the fins; then with a sudden thrust he removes the intestines and the eggs. The body goes into a tank of water; and the head is dropped into a box on a flat-boat, and goes down the river to be made into salmon oil. Next, the body is brought to another table; and Quong Sang, with a machine like a feed-cutter, cuts it into pieces each just as long as a one-pound can. Then Ah Sam, with a butcher-knife, cuts these pieces into strips just as wide as the can. Next Wan Lee, the "China boy," brings down a hundred cans from the loft where the tinners are making them, and into each can puts a spoonful of salt. It takes just six salmon to fill a hundred cans. Then twenty Chinamen put the pieces of meat into the cans, fitting in little strips to make them exactly full. Ten more solder up the cans, and ten more put the cans into boiling. water till the meat is thoroughly cooked, and five more punch a little hole in the head of each can to let out the air. Then they solder them up again, and little girls paste on them bright-colored labels showing merry little cupids riding the happy salmon up to the cannery door, with Mount Tacoma and Cape Disappointment in the background; and a legend underneath says that this is "Booth's," or "Badollet's Rest," or "Hume's," or " Clark's," or "Kinney's Superfine Salt Water Salmon." Then the cans are placed in cases, forty-eight in a case, and five hundred thousand cases are put up every year. Great ships come to Astoria, and are loaded with them; and they carry them away to London and San Francisco and Liverpool and New York 
and Sidney and Valparaiso; and the man at the corner grocery sells them at twenty cents a can.

All this time our salmon is going up the river, eluding one net as by a miracle, and soon having need of more miracles to escape the rest; passing by Astoria on a fortunate day, - which was Sunday, the day on which no man may fish if he expects to sell what he catches, - till finally he came to where nets were few, and, at last, to where they ceased altogether. But there he found that scarcely any of his many companions were with him; for the nets cease when there are no more salmon to be caught in them. So he went on, day and night, where the water was deepest, stopping not to feed or loiter on the way, till at last he came to a wild gorge, where the great river became an angry torrent, rushing wildly over a huge staircase of rocks. But our hero did not falter; and summoning all his forces, ine plunged into the Cascades. The current caught him and dashed him against the rocks. A whole row of silvery scales came off and glistened in the water like sparks of fire, and a place on his side became black-and-red, which, for a salmon, is the same as being black-and-blue for other people. His comrades tried to go up with him; and one lost his eye, one his tail, and one had his lower jaw pushed back into his head like the joint of a telescope. Again he tried to surmount the Cascades; and at last he succeeded, and an Indian on the rocks above was waiting to receive him. But the Indian with his spear was less skilful than he was wont to be, and our hero escaped, losing only a part of one of his fins; and with him came one 
other, and henceforth these two pursued their journey together.

Now a gradual change took place in the looks of our salmon. In the sea he was plump and round and silvery, with delicate teeth in a symmetrical mouth. Now his silvery color disappeared, his skin grew slimy, and the scales sank into it; his back grew black, and his sides turned red, - not a healthy red, but a sort of hectic flush. He grew poor; and his back, formerly as straight as need be, now developed an unpleasant hump at the shoulders. His eyes - like those of all enthusiasts who forsake eating and sleeping for some loftier aim - became dark and sunken. His symmetrical jaws grew longer and longer, and meeting each other, as the nose of an old man meets his chin, each had to turn aside to let the other pass. His beautiful teeth grew longer and longer, and projected from his mouth, giving him a savage and wolfish appearance, quite at variance with his real disposition. For all the desires and ambitions of his nature had become centred into one. We may not know what this one was, but we know that it was a strong one; for it had led him on and on, - past the nets and horrors of Astoria; past the dangerous Cascades; past the spears of Indians; through the terrible flume of the Dalles, where the mighty river is compressed between huge rocks into a channel narrower than a village street; on past the meadows of Umatilla and the wheat-fields of Walla Walla; on to where the great Snake River and the Columbia join; on up the Snake River and its eastern branch, till at last 
he reached the foot of the Bitter Root Mountains in the Territory of Idaho, nearly a thousand miles from the ocean which he had left in April. With him still was the other salmon which had come with him through the Cascades, handsomer and smaller than he, and, like him, growing poor and ragged and tired.

At last, one October afternoon, our finny travellers came together to a little clear brook, with a bottom of fine gravel, over which the water was but a few inches deep. Our fish painfully worked his way to it; for his tail was all frayed out, his muscles were sore, and his skin covered with unsightly blotches. But his sunken eyes saw a ripple in the stream, and under it a bed of little pebbles and sand. So there in the sand he scooped out with his tail a smooth round place, and his companion came and filled it with orange-colored eggs. Then our salmon came back again; and softly covering the eggs, the work of their lives was done, and, in the old salmon fashion, they drifted tail foremost down the stream.

They drifted on together for a night and a day, but they never came to the sea. For the salmon has but one life to live, and it ascends the river but once. The rest lies with its children. And when the April sunshine fell on the globules in the gravel, these were wakened into life. With the early autumn rains, the little fishes were large enough to begin their wanderings. They dropped down the current in the old salmon fashion. And thus they came into the great river and drifted away to the sea. 


\section{JOHNNY DARTERS. ${ }^{1}$}

$\mathrm{NY}$ one who has ever been a boy and can
remember back to the days of tag-alders, yellow cowslips, and an angle-worm on a pin-hook, will recall an experience like this: You tried some time to put your finger on a little fish that was lying, apparently asleep, on the bottom of the stream, half hidden under a stone or a leaf, his tail bent around the stone as if for support against the force of the current. You will remember that when your finger came near the spot where he was lying, the bent tail was straightened, and you saw the fish again resting, head up-stream, a few feet away, leaving you puzzled to know whether you had seen the movement or not. You were trying to catch a Johnny Darter. Nothing seems easier, but you did not do it.

Having by well-understood stratagem succeeded where you failed, allow us to give you that acquaintance which he so deftly declined.

In all clear streams from Maine to Mexico the Johnny Darters are found; and the boy who does not know them has missed one of the real pleasures of a boy's life. All of them are very little fishes, - some not more than two inches long, and

1 The original version of this paper was the joint work of the late Professor Herbert Edson Copeland and the writer. - D. S. J. 
the very largest but six or eight. But small though they are, they are the most interesting in habits, the most graceful in form, and many of them the most brilliant in color of all fresh-water fishes. The books call them "Darters; " for one of the first species known was named Boleosoma, and that in Greek means "dart body," - a name most appropriate to them all. The realistic dwellers in the Ohio Valley call some of them "Hog-fish," and the boys call them "Johnnies." Certainly the boys ought to know, - and Johnnies they are, and Darters they are; so Johnny Darters they shall be. Their first introduction to science was in 1819 , when Rafinesque gave to them their scientific name of Etheostoma. This name seems to mean "strainer-mouth;" but the "eccentric naturalist," whose peculiar use of the Greek language was not the least of his eccentricities, says that it means "various-mouth," because no two of those he knew ${ }^{1}$ have the mouth alike. But whatever it may mean, Etheostoma is their name, and Rafinesque their godfather; and we may call them Johnnies for short.

Rafinesque said of the Johnnies that he knew "they are good to eat fried." I suppose that he had tried them; but we have not. We should as soon think of filling our pan with wood-warblers as to make a meal of them. The good man goes a-fishing not for " pot-luck," but to let escape " the Indian within him."

The Johnny Darter deserves our especial atten-

1 These were Etheostoma fiabellare, Percina caprodes, and Diple. sion blennioides. 
tion in this Centennial year, for he is altogether an American product. He has all that ardent desire for perfect freedom that is supposed to be native to this continent. Unless all appearance of captivity be concealed in a well-kept aquarium, he will quickly lie on the bottom, dead. Here, at the beginning (for much as we may regret the fact, the death of some individual must precede our acquaintance with the group, and even to some extent with the individual himself), we observe two noteworthy facts: the fish in dying does not turn over, and does not rise to the surface. On dissection, we find that the air-bladder is only rudimentary, being structurally, but not functionally, present, - a distinction not without meaning in these days of evolutionary hypotheses. If our tank be so arranged that the conditions are nearly natural, there being an abundance of stones and weeds on the bottom, our Johnnies will cheerfully live with us, and we shall be ready to study their individual peculiarities, or, as Boyesen's "Scientific Vagabond " would have said, their " psychology."

For it must be known that while all fish are fish, they are so only as all men are men. The children of one family are not more unlike one another than the fishes of one brood might be if the sickly ones and the lazy ones were as carefully guarded as are ours. As it is, they have their individuality. One is constantly darting over and among the stones, never resting, moving his head from side to side when his body is for a moment still. Another will lie for hours motionless under a stone, moving only for a few inches when pushed out 
with a stick. These peculiarities of temperament are important factors in the problem of life; and from such differences under varying conditions, may have resulted forms which we now designate as different species.

But we must leave these general questions for the present, and tell the story of the Johnny Darters that live in our aquarium. ${ }^{1}$

First of these in size and therefore in dignity comes the Log Perch or Hog-fish (Percina caprodes Rafinesque). This is the giant of the family, - the most of a fish, and therefore the least of a darter. It may be readily known by its zebra-like colors. Its hue is pale olive,-silvery below, darker above. On this ground-color are about fifteen black vertical bars or incomplete rings, alternating with as many shorter bars which reach only half-way down the side. The hindmost bar forms a mere spot on the base of the tail, and there are many dots and speckles on the fins. The body is long and slender, spindle-shaped, and firm and wiry to the touch. The head is flat on top, and tapers into a flat-pointed snout which is squared off at the end like the snout of a pig; and this resemblance is heightened by the form of the small mouth underneath it. From this pig-like snout has come the scientific name caprodes. This is a translation of the older name of " hogfish," which Rafinesque heard applied to it in his time, and which is still used in the same regions.

Percina reaches a length of six or eight inches,

1 At Indianapolis, Indiana. All the species here mentioned, and some others, are found in the White River, near Indianapolis. 
and it may readily be caught on a small hook baited with a worm. We often meet an urchin with two or three of them strung through the gills on a forked stick, along with " red-eyes," "stonetoters," "horny-heads," and other " boys' fish." At such times we generally buy the hog-fish for a cent, cut it open to look at the air-bladder, which the books say it does not have, and then lay it away with the rest of our treasures in the bottle of alcohol. We find Percina usually in rapid and rather deep water, - as deep as we can wade in when seining in hip-boots. We rarely find them small enough for ordinary aquarium purposes; and the living specimen before us, though wonderfully quick and graceful in its movements, has shown little that is noteworthy, save his courage, his fondness for angle-worms, and a possible disposition to bury himself in the sand. There is something in the expression of his face, as he rests on his "hands and feet" on a stone, that is remarkably lizardlike, suggesting the Blue-tailed Skink (Eumeces fasciatus).

We next come to the fine gentleman of the family, the Black-sided Darter (Hadropterus aspro Cope and Jordan). This one we may know by its colors. The ground hue is a salmon yellow; the back is regularly and beautifully marbled with black in a peculiar and handsome pattern. On the sides, from the head to the tail, runs a jet-black band, which is widened at intervals into rounded spots which contrast sharply with the silvery color of the belly; or we may say that on each side is a chain of confluent round black blotches. Sometimes 
the fishes seem to fade out; these blotches grow pale, and no longer meet; but in an instant they may regain their original form and shade. This latter change can be induced by the offer of food, and it is of course due to muscular action on the scales which cover the darker pigment. A male in our aquarium underwent almost instantly an entire change of coloration upon the introduction of a female fish of the same species recognized by him as his affinity. Although the two have been together for some weeks, the novelty has not yet worn off; and although his colors vary much from one hour to another, he has never yet quite reverted to his original hues. The form of the blacksided darter is more graceful than that of any other, and his movements have little of that angular jerkiness which characterizes his relatives.

The fins of Hadrcpterus, like those of Percina, are long and large, the number of dorsal spines being about fourteen. A notable peculiarity in both species is the presence of a row of shields, or enlarged scales, along the middle line of the abdomen. These may help to protect that part from the friction of the stony bottom. They seem to be shed sometimes; but when or why this happens we do not know. Hadropterus delights in clear running water, and may be found in most streams south and west of New York. It is especially desirable for aquaria, being hardier than any other fish as pretty, and prettier than any other fish as hardy, and withal with " a way of his own," as an Irish laborer, Barney Mullins, once said to us of Thoreau. 
One of the most simply beautiful of all fishes is the Green-sided Darter (Diplesion blennioides Rafinesque). He is not, like the Pocilichthys, an animated rainbow; but he has the beauty of green grass, wild violets, and mossy logs. As we watch him in the water, with his bright blended colors and gentle ways, once more, with Old Izaak, "we sit on cowslip banks, hear the birds sing, and possess ourselves in as much quietness as the silent silver streams which we see glide so quietly by us." During the ordinary business of the year Diplesion, like most sensible fishes and men, dresses plainly. It is not easy to get time for contemplation when the streams are low and food is scarce. Besides, a plain coat may ward off danger as well as facilitate attack. At all times, however, he may be known by these marks: the fins are all large; the back is covered with zigzag markings, while. on the lower part of the sides are eight or nine $w$-shaped olive spots. These are more or less connected above, and sometimes form a wavy line. The eyes are prominent; the snout is very short and rounded; while the little inferior mouth is puckered up as if for saying "prunes and prisms, prunes and prisms." But when the first bluebirds give warning by their shivering and bodiless notes that spring is coming, then Diplesion puts on his wedding-clothes, and becomes in fact the greensided darter. The dorsal fins become of a bright grass-green, with a scarlet band at the base of each ; the broad anal has a tinge of the deepest emerald; while every spot and line upon the side has turned from an undefined olive to a deep rich green, such 
as is scarcely found elsewhere in the animal world excepting on the heads of frogs. The same tint shines out on the branching rays of the caudal fin, and may be seen struggling through the white of the belly. The blotches nearest the middle of the I back become black, and thickly sprinkled everywhere are little shiny specks of a clear bronzeorange. In the aquarium Diplesion is shy and retiring, - too much of a fine lady to scramble for angle-worms or to snap at the "bass-feed." She is usually hidden among the plants, or curled up under an arch of stones or in a geode.

We never tired of watching the little Johnny, or Tessellated Darter (Boleosoma nigrum Rafinesque). Although our earliest aquarium friend, - and the very first specimen showed us by a rapid ascent of the river-weed how "a Johnny could climb trees," - he has still many resources which we have never learned. Whenever we try to catch him with the hand, we begin with all the uncertainty that characterized our first attempts, even if we have him in a two-quart pail. We may know him by his short fins, his first dorsal having but nine spines, and by the absence of all color save a soft yellowish brown, which is freckled with darker markings. The dark brown on the sides is arranged in seven or eight $w$-shaped marks, below which are a few flecks of the same color. Covering the sides of the back are the wavy markings and dark specks which have given the name of the "Tessellated Darter;" but Boleosoma is a braver name, and we even prefer "Boly" for short. In the spring the males have the head jet-black; and 
this dark color often extends on the back part of the body, so that the fish looks as if he had been taken by the tail and dipped into a bottle of ink. But with the end of the nuptial season, this color disappears, and the fish regains his normal strawy hue.

The head in Boleosoma resembles that of Diplesion; but the habit of leaning forward over a stone, resting on the front fins, gives a physiognomy even more frog-like. His actions are, however, rather bird-like; for he will strike attitudes like a tufted titmouse, and he flies rather than swims through the water. He will, with much perseverance, push his body between a plant and the side of the aquarium, and balance himself on the slender stem. Crouching cat-like before a snail-shell, he will snap off the horns which the unlucky owner pushes timidly out. But he is often less dainty, and seizing the animal by the head, he dashes the shell against the glass or a stone until he pulls the body out or breaks the shell. Boly, alas! is the "Quaker of our aquarium " only in appearance.

Gayest of all the darters, and indeed the gaudiest of all fresh-water fishes, is the Rainbow Darter (Pecilichthys coruleus Storer). This is a little fish, never more than three inches long, and usually about two. Everywhere, throughout the northern parts of the Mississippi Valley, it makes its home in the ripples and shallows of the rivers and in the shady retreats of all the little brooks. The male fish is greenish above, with darker blotches, and its sides are variegated with oblique bands alternately of indigo-blue and deep orange, the orange 
often edged with patches of white. The cheeks are deep blue, the breast deep orange; while the expanded fins are gorgeous in scarlet, indigo, and crimson. The female, as is usually the case when the male of the species is resplendent, is plainly colored, - a speckly green, with no trace of blue or orange.

When the War of the Rebellion broke out, there were some good people who were anxiously looking for some sign or omen, that they might know on which side the "stars in their courses" were fighting. It so happened that in a little brook in Indiana, called Clear Creek, some one caught a rainbow darter. This fish was clothed in a new suit of the red, white, and blue of his native land, in the most unmistakably patriotic fashion. There were some people who had never seen a darter before, and who knew no more of the fishes in their streams than these fishes knew of them, by whom the coming of this little "soldier-fish" into their brooks was hailed as an omen of victory. Of course, these little fishes had really "always been there." They were there when America was discovered and for a long time before, but the people had not seen them. The warblers lived, you remember, in Spalding's woods at Concord; but Spalding did not know that they were there, and they had no knowledge of Spalding. So with the darters in Spalding's brooks. Still, when the day comes when history shall finally recount all the influences which held Indiana to her place in the Union, shall not, among greater things, this least of little fishes receive its little meed of praise? 
Pecilichthys is a chubby little fish, as compared with the other darters. In its movements it is awkward and ungraceful, though swift and savage as a pike. One of the mildest of its tricks which we have noticed, is this. It would gently put its head over a stone and catch a water-boatman by one of its swimming legs, release it, catch it again and again release it, until at last the boatman, evidently much annoyed, swam away out of its reach. It will follow to the surface of the water a piece of meat suspended by a string. It is more alert in discovering this than a hungry sunfish or rockbass, and it can be led around like a pet lamb by a thread to which is fastened a section of a worm.

A more beautiful fish than this - beyond question the handsomest of them all - is the Bluebreasted Darter (Nothonotus camurus Cope). It is a deep olive-green little fish, sprinkled over with dots of carmine like a brook trout. Its breast is of a deep ultramarine blue, and its fins gayly variegated with blue, yellow, and crimson. But we hardly learned to know it as an aquarium acquaintance; for we found it but twice, both times in the clearest of water, and our specimens never survived confinement more than two or three hours. We can only say of their habits that they died where other darters lived, and that before they died all other fishes seemed cheap and common beside them.

The darter of darters is the Fan-tail (Etheostoma flabellare Rafinesque). Hardiest, wiriest, wariest of them all, it is the one which is most expert in catching other creatures, and the one which most 
surely evades your clutch. You can catch a weasel asleep when you can put your finger on one of these. It is a slim, narrow, black, piraterigged little fish, with a long pointed head, and a projecting, prow-like lower jaw. It carries no flag, but is colored like the rocks, among which it lives. It is dark brown in hue, with a dusky spot on each scale, so that the whole body seems covered with lengthwise stripes; and these are further relieved by cross-bands of the same color. Its fins, especially the broad fan-shaped caudal, are likewise much checkered with spots of black. The spines of the dorsal fin are very low; and each of these in the male ends in a little fleshy pad of a rusty-red color, the fish's only attempt at ornamentation.

The fan-tail darter chooses the coldest and swiftest waters; and in these, as befits his form, he leads an active, predatory life. He is the terror of watersnails and caddis-worms, and the larvæ of mosquitoes. In the aquarium this darter is one of the most interesting of fishes; for though plainly colored it is very handsome, and in its movements is the most graceful of all the darters. Its mouth opens wider than that of any of the others, and it is fuller of bristling teeth. Its large, yellow-rimmed black eyes are ever on the watch. The least of a "fish" and the most of a darter, the fan-tail is worthily left as the type of the genus Etheostoma, in which it was first placed by its discoverer, Rafinesque.

We often brought home with us a "Johnny," " Speck," or "Crawl-a-bottom," of a different type from any of those whose habits we already knew. It had a very sharp nose which projected over its 
mouth; its body was exceedingly slim and round, as transparent as jelly, but hard and firm to the touch. Its belly and much of its back were quite bare of scales, and those along its sides were small and inconspicuous. After much searching through the scattered descriptions which Eastern naturalists have given us of the darters found in their bottles of alcohol, we decided that our little friend was the Pellucid Darter (Ammocrypta pellucida Baird), better called the "Sand Darter" for reasons soon to be given.

Our aquarium had been arranged for the convenience of our other Etheostomine friends, and the bottom was thickly covered with stones among which a small fish might easily hide. Several days passed after the introduction of the first Ammocrypta ${ }^{1}$ which survived the change of water, when we noticed that it had disappeared. Careful search among the stones and around the geode only made it the more certain that it had gone, and increased our wonder as to the way; for surely it had not been eaten, nor had it jumped out, unless, like Ariel, it could assume a "shape invisible." Finally, after going over every inch of the ground, there was discovered, under the nose of Boleosoma, which was standing as usual on its hands and tail, the upper edge of a caudal fin, and on each side of Boly's tail appeared a little black eye set in a yellow frame. Pleurolepis was buried! Was he dead? Slowly one eye was closed in a darter's inimitable way, - for they can outwink all animals

1 Or, as we then called it, Pleurolepis; this name being earlier, but already preoccupied by a genus of extinct ganoid fishes. 
in creation except owls, - and a touch of a finger on its tail showed that it had lost none of its activity. It was quite improbable that it had been buried so completely by accident. We therefore cleared of stones a small spot, leaving the hard white sand exposed, and awaited developments. Then for days we watched it closely, only to learn that it could bury itself with great celerity, for it was not caught in the act. But our patience was at last rewarded; for one morning, as we came out to breakfast, it put its nose, that we now know has a tip nearly as hard as horn, against the bottom, stood up nearly straight on its head, and with a swift beating of the tail to right and left was in less than five seconds completely buried. The sand had been violently stirred, of course; and just as it had nearly settled, probably in less than half a minute, its nose was put quietly out, and settling back left the twinkling eyes and narrow forehead alone visible.

Since then we have kept scores of them in an aquarium arranged especially for their convenience, and have often seen.them burrow into the sand. They will remain buried so long as the water is pure and cool. Indeed, we now rely almost entirely on them to warn us when the water needs changing. When this need is felt, they come out of the sand and lie on the bottom panting violently. We have been unable to discover any immediate incentive for the act. It seems to be entirely unpremeditated. A number of them in confinement lie helplessly on the bottom, motionless and slowly breathing, when one suddenly 
starts and buries his head and neck in the now whirling sand, by a motion as quick as thought; his tail beats frantically about, and when again the clean sand lies smooth on the bottom, the little eyes are looking at you like two glistening beads, as if to witness your applause at so clever a trick.

We have never seen Ammocrypta taste of food, nor do we ever expect to do so; for although its mouth bristles with teeth, its small size forbids an attack on any game which we can offer. Its quiescent habits and the character of the bottoms to which it confines itself seem to indicate that its prey is minute if not microscopic. But speculation about what we do not know as to its food might lead us to speculation as to the origin of its characteristic features, - how, for instance, the hard snout, the transparent muscles, and the burrowing habits are consequent on its loss of scales, or how the loss of unnecessary scales and of pigment cells is consequent on its burrowing habits. Then, when we have finished these matters, we might inquire how it came about that there are "Johnny Darters" at all, and why no other continent has them. And we might go on with endless queries like these, which would take us far beyond the purpose of this article. We have wished only to introduce our aquarium friends, and to commend them to all lovers of beautiful things in Nature. 


\section{THE SALMON FAMILY.}

C F all the families of fishes, the one most interesting from almost every point of view is that of the Salmonida, the Salmon family. As now restricted, it is not one of the largest families, as it comprises less than a hundred species; but in beauty, activity, gaminess, quality as food, and even in size of individuals, different members of the group stand easily with the first among fishes. The following are the chief external characteristics which are common to the members of the family as here understood; the Argentinidae and the $S a$ langida, usually included with them, being here placed in separate groups:-

Body oblong or moderately elongate, covered with cycloid scales of varying size. Head naked. Mouth terminal or somewhat inferior, varying considerably among the different species, those having the mouth largest usually having also the strongest teeth. Maxillary provided with a supplemental bone, and forming the lateral margin of the upper jaw. Pseudobranchiæ present. Gill-rakers varying with the species. Opercula complete. No barbels. Dorsal fin of moderate length, placed near the middle of the length of the body. Adipose fin well developed. Caudal fin forked. Anal fin moderate or rather long. Ventral fins nearly 
median in position. Pectoral fins inserted low. Lateral line present. Outline of belly rounded. Vertebræ in large number, usually about sixty.

The stomach in all the Salmonida is siphonal, and at the pylorus are many ( 15 to 200) comparatively large pyloric cœca. The air-bladder is large. The eggs are usually much larger than in fishes generally, and the ovaries are without special duct, the ova falling into the cavity of the abdomen before exclusion. The large size of the eggs, their lack of adhesiveness, and the readiness with which they may be impregnated, render the Salmonide peculiarly adapted for artificial culture.

The Salmonida are peculiar to the North Temperate and Arctic regions, and within this range they are almost equally abundant wherever suitable waters occur. Some of the species, especially the larger ones, are marine and anadromous, living and growing in the sea, and ascending fresh waters to spawn. Still others live in running brooks, entering lakes or the sea when occasion serves, but not habitually doing so. Still others are lake fishes, approaching the shore or entering brooks in the spawning season, at other times retiring to waters of considerable depth. Some of them are active, voracious, and gamy; while others are comparatively defenceless, and will not take the hook. They are divisible into eight easily recognized genera, - Coregonus, Plecoglossus, Brachymystax, Stenodus, Thymallus, Oncorhynchus, Salmo, and Salvelinus. These groups may be discussed in order. 
The genus Coregonus, which includes the various species known in America as lake white-fish, is distinguishable in general by the small size of its mouth, the weakness of its teeth, and the large size of its scales. The teeth, especially, are either reduced to very slight asperities, or else are altogether wanting. The species reach a length of one to two feet or more. With scarcely an exception they inhabit clear lakes, and rarely enter streams except to spawn. In far northern regions they often descend to the sea; but in the latitude of the United States this is rarely possible for them, as they are unable to endure impurities in the water. They seldom take the hook, and rarely feed on other fishes. From their restriction to the waters of the different lake systems in which they live, numerous local varieties have been developed both in Europe and America, distinguished by characters less constant and less important than those which separate the different species. European writers have somewhat inconsistently regarded these varying and intangibly different forms as distinct species, and many of them have come to the conclusion that almost every lake system of Scandinavia, Scotland, and Russia has several species which are peculiar to it. Dr. Günther observes that "the species of this genus are not less numerous than those of Salmo, some having a very extended geographical range, whilst others are confined to very limited localities. They are less subject to variation than the trout, and therefore more easily characterized and distinguished. Hence we find that naturalists who 
look with distrust on the different species of Salmo are quite ready to admit those of Coregonus."

It seems to me, however, that the variableness in Coregonus has been underestimated. The American species at least are all fishes of wide range, varying considerably with their surroundings.

None of the other species reach the size, or have the value as food, of our common white-fish. The species of Coregonus differ from each other in the form and size of the mouth, in the form of the body, and in the development of the gill-rakers. These differences have led to the establishment of about five sections, or subgenera, the extremes of which differ remarkably, but which gradually pass from one into another. Of the species, the following are among the most noteworthy:-

Coregonus oxyrhynchus - the Schnäbel of Holland, Germany, and Scandinavia - has the mouth. very small, the sharp snout projecting far beyond it. No species similar to this is found in America.

The Rocky Mountain White-fish (Coregonus williamsoni) has also a small mouth and projecting snout, but the latter is blunter and much shorter than in $C$. oxyrhynchus. This is a small species abounding everywhere in the clear lakes of the Rocky Mountains and the Sierra Nevada, from Colorado to Vancouver Island. It is a handsome fish, and excellent as food.

Closely allied to Coregonus williamsoni is the Pilot-fish, Shad-waiter, Round-fish, or Menomonee White-fish (Coregonus quadrilateralis). This species is found in the Great Lakes, the Adirondack 
region, the lakes of New Hampshire, and thence northwestward to Alaska, abounding in cold deep waters, its range apparently nowhere coinciding with that of Coregonus williamsoni.

The common White-fish (Coregonus clupeiformis) is the largest in size of the species of Coregonus, and is unquestionably the finest as an article of food. It varies considerably in appearance with age and condition, but in general it is proportionately much deeper than any of the other smallmouthed Coregoni. The adult fishes develop a considerable fleshy hump at the shoulders, which causes the head, which is very small, to appear disproportionately so. The white-fish spawns in November and December, on rocky shoals in the great lakes. Its food, which was for a long time unknown, was ascertained by Dr. P. R. Hoy to consist chiefly of deep-water crustaceans, with a few mollusks, and larvæ of water insects. "The white-fish," writes Mr. James W. Milner, "has been known since the time of the earliest explorers as pre-eminently a fine-flavored fish. In fact, there are few table-fishes its equal. To be appreciated in its fullest excellence, it should be taken fresh from the lake and broiled. Father Marquette, Charlevoix, Sir John Richardson, - explorers who for months at a time had to depend on the whitefish for their staple article of food-bore testimony to the fact that they never lost their relish for it, and deemed it a special excellence that the appetite never became cloyed with it." The range of the white-fish extends from the lakes of New York and New England northward to the Arctic Circle. 
The "Otsego bass" of Otsego Lake in New York, celebrated by De Witt Clinton, is the ordinary white-fish.

Allied to the American white-fish, but smaller in size, is the Lavaret, Weissfisch, Adelfisch, or Weissfelchen (Coregonus lavaretus), of the mountain lakes of Switzerland, Germany, and Sweden. Several other related species occur in northern Europe and Siberia.

Another American species is the Sault Whitefish, Lake Whiting, or Musquaw River White-fish (Coregonus labradoricus). Its teeth are stronger, especially on the tongue, than in any of our other species, and its body is slenderer than that of the white-fish. It is found in the upper Great Lakes, in the Adirondack region, in Lake Winnepesaukee, and in the lakes of Maine and New Brunswick. It is said to rise to the fly in the Canadian lakes. This species runs up the St. Mary's River, from Lake Huron to Lake Superior, in July and August. Great numbers are snared or speared by the Indians at this season at the Sault Ste. Marie.

The smallest and handsomest of the American white-fish is the Cisco of Lake Michigan (Coregonus hoy i). It is a slender fish, rarely exceeding ten inches in length, and its scales have the brilliant silvery lustre of the Moon-eye and the Lady-fish.

The Lake Herring, or Cisco (Coregonus artedi), is, next to the white-fish, the most important of the American species. It is more elongate than the others, and has a comparatively large mouth, with projecting under jaw. It is correspondingly more voracious, and often takes the hook. During the 
spawning season of the white-fish the lake herring feeds on the ova of the latter, thereby doing a great amount of mischief. As food, this species is fair, but much inferior to the white-fish. Its geographical distribution is essentially the same, but to a greater degree it frequents shoal waters. In the small lakes around Lake Michigan, in Indiana and Wisconsin (Tippecanoe, Geneva, Oconomowoc, etc.), the cisco has long been established; and in these waters its habits have undergone some change, as has also its external appearance. These lake ciscoes remain for most of the year in the depths of the lake, coming to the surface only in search of certain insects, and to shallow water only in the spawning season. This periodical disappearance of the cisco has led to much foolish discussion as to the probability of their returning by an underground passage to Lake Michigan during the periods of their absence. One author, confounding " cisco" with " siscowet," has assumed that this underground passage leads to Lake Superior, and that the cisco is identical with the fat lake trout which bears the latter name. The name "lake herring" alludes to the superficial resemblance which this species possesses to the marine herring, a fish of quite a different family.

Closely allied to the lake herring is the Blue-fin of Lake Michigan and of certain lakes in New York (Coregonus nigripinnis), a fine large species inhabiting deep waters, and recognizable by the blue-black color of its lower fins. In Alaska and Siberia are still other species of the cisco type (Coregonus lauretta, C. merki, C.nelsoni); and in 
Europe very similar species are the Scotch Vendace (Coregonus vandesius) and the Scandinavian Lok-Sild (lake herring), as well as others less perfectly known.

The Tullibee, or "Mongrel White-fish" (Coregonus tullibee), has a deep body, like the shad, with the large mouth of the ciscoes. Fishermen think it a hybrid between Coregonus clupeiformis and $C$. artedi. It is found in the Great Lake region and northward, and very little is known of its habits. A similar species (Coregonus cyprinoides) is recorded from Siberia, - a region which is peculiarly suited for the growth of the Coregoni, but in which the species have never received much study.

Allied to the Coregoni is Plecoglossus altivelis, a small fish of the waters of Japan and Formosa. It has small, compressed, serrated, movable teeth in the jaws. This is said to be an annual fish, the life. of each individual ceasing at the end of the season of reproduction.

Another little-known form, intermediate between the white-fish and the salmon, is Brachymystax lenock, a large fish of the mountain streams of Siberia. Only the skins brought home by Pallas about a century ago seem to be known as yet. According to Pallas, it sometimes reaches a weight of eighty pounds.

Still another genus, intermediate between the white-fish and the salmon, is Stenodus, distinguished by its elongate body, feeble teeth, and projecting lower jaw. The Inconnu, or Mackenzie River Salmon (Stenodus mackenzii) belongs to this genus. It reaches a weight of twenty pounds or 
more, and in the far north is a food fish of good quality. Little is recorded of its habits, and few specimens exist in museums. Species of Stenodus are said to inhabit the Volga, Obi, Lena, and other northern rivers; but as yet little is definitely known of them.

The Grayling (Thymallus), termed by Saint Ambrose "the flower of fishes," is likewise intermediate between the white-fish and the trout, having larger scales and feebler teeth than the latter. The teeth on the tongue, found in all the trout and salmon, are obsolete in grayling. The chief distinctive peculiarity of the genus Thymallus is the great development of the dorsal fin, which has more rays (20 to 24 ) than are found in any other of the Salmonida, and the fin is also higher. All the species are gayly colored, the dorsal fin especially being marked with purplish or greenish bands and bright rose-colored spots; while the body is mostly purplish-gray, often with spots of black. Most of the species rarely exceed a foot in length, but northward they grow larger. Grayling weighing five pounds have been taken in England; and according to Dr. Day, they are said in Lapland to reach a weight of eight or nine pounds. The grayling in all countries frequent clear, cold brooks, and rarely, if ever, enter the sea, or even the larger lakes. They are said to congregate in small shoals in the streams, and to prefer those which have a succession of pools and shallows, with a sandy or gravelly rather than rocky bottom. The grayling spawns on the shallows in April or May (in England). It is said to be non-migratory 
in its habits, depositing its ova in the neighborhood of its usual haunts. The ova are said to be far more delicate and easily killed than those of the trout or charr. The grayling and the trout often inhabit the same waters, but not altogether in harmony. It is said that the grayling devour the eggs of the trout. It is certain that the trout feed on the young grayling. As a food-fish, the grayling, of course, ranks high; but the true sportsman will hardly seek such fish as these to fill his frying-pan. They are considered gamy fishes, although less strong than the brook-trout, and perhaps less wary. The five or six known species of grayling are very closely related, and are doubtless comparatively recent offshoots from a common stock, which has now spread itself widely through the northern regions.

The common Grayling of Europe (Thymallus thymallus) is found throughout northern Europe, and as far south as the mountains of Hungary and northern Italy. The name Thymallus was given by the ancients, because the fish, when fresh, had the odor of water thyme, - an odor which the duller sense of the moderns now fails to detect. Grayling belonging to this or other species are found in the waters of Russia and Siberia.

The American Grayling (Thymallus signifer) is widely distributed in British America and Alaska. In several streams in northern Michigan and in Montana occurs a dwarfish variety of this species, known to anglers as the Michigan Grayling (Thymallus signifer ontariensis). ${ }^{1}$ This form has a

1 Thymallus tricolor Cope $=$ Thymallus montanus Milner. 
longer head, rather smaller scales, and the dorsal fin rather lower than in the northern form (signifer); but the constancy of these characters in specimens from intermediate localities is yet to be proved. It is probable that the grayling once had a wider range to the southward than now, and that so far as the waters of the United States are concerned, it is tending towards extinction. This tendency is, of course, being accelerated in Michigan by lumbermen and anglers. The colonies of grayling in Michigan and Montana are probably remains of a post-glacial fauna.

The genus Oncorhynchus contains those species of Salmonide which have the greatest size and value. They are in fact, as well as in name, the king salmon. The genus is closely related to Salmo, with which it agrees in general as to the structure of its vomer, and from which it differs in the increased number of anal rays, branchiostegals, pyloric cœeca, and gill-rakers. The character most convenient for distinguishing Oncorhynchus, young or old, from all the species of Salmo, is the number of developed rays in the anal fin. These in Oncorhynchus are thirteen to twenty, in Salmo nine or ten.

The species of Oncorluynchus have long been known as anadromous salmon, confined to the North Pacific. The species were first made known one hundred and thirty years ago, by that most exact of early observers, Steller, who described and distinguished them with perfect accuracy, under their Russian vernacular names. These Russian names were, in I792, adopted by Walbaum as 
specific names, in giving to these animals a scientific nomenclature. Since Steller's time, writers of all degrees of incompetence, and writers with scanty material or with no material at all, have done their worst to confuse our knowledge of these salmon, until it became evident that no exact knowledge of any of the species remained. In the current system of a few years ago, the breeding males of the five species known to Steller constituted a separate genus of many species (Oncorhynchus Suckley); the females were placed in the genus Salmo, and the young formed still other species of a third genus, called Fario, supposed to be a genus of trout. The young breeding males (grilsc) of one of the species (Oncorhynchus nerka) made still a fourth genus designated as Hypsifario. Not one of the writers on these fishes of twenty-five years ago knew a single species definitely, at sight, or used. knowingly in their descriptions a single character by which species are really distinguished. Not less than thirty-five nominal species of Oncorhynchus have already been described from the North $\mathrm{Pa}$ cific, although, so far as is now known, only the five originally noticed by Steller really exist. The descriptive literature of the Pacific salmon is among the very worst extant in science. This is not, however, altogether the fault of the authors, but it is in great part due to the extraordinary variability in appearance of the different species of salmon. These variations are, as will be seen, due to several different causes, notably to differences in surroundings, in sex, and in age, and in conditions connected with the process of reproduction. 
The writer and his associate, Professor Charles H. Gilbert, have had, under the auspices of the United States Fish Commission, better opportunities to study the different species of Oncorhynchus than have fallen to the lot of any other ichthyologists. The following discussion of the different species is condensed from our report to the United States Census Bureau, portions of which were published in the "American Naturalist" for March, I88 I. Entirely similar conclusions have been independently reached by Dr. Tarleton $\mathrm{H}$. Bean, who visited Alaska in 1880 , and whose means of studying the species have been scarcely less extensive.

There are five species of salmon (Oncorhynchus) in the waters of the North Pacific. We have at present no evidence of the existence of any more on either the American or the Asiatic side. These species may be called: (I) the Quinnat, or King Salmon, (2) the Blue-back Salmon, or Red-fish, (3) the Silver Salmon, (4) the Dog Salmon, and (5) the Humpback Salmon; or (1) Oncorhynchus tschawytscha, (2) Oncorhynchus nerka, (3) Oncorhynchus kisutch, (4) Oncorhynchus keta, and (5) Oncorhynchus gorbuscha. All these species are now known to occur in the waters of Kamtschatka as well as in those of Alaska and Oregon. These species, in all their varied conditions, may usually be distinguished by the characters given below. Other differences of form, color, and appearance are absolutely valueless for distinction, unless specimens of the same age, sex, and condition are compared.

The Quinnat Salmon (Oncorhynchus tschawytscha) 
has an average weight of 22 pounds, but individuals weighing 70 to 100 pounds are occasionally taken. It has about 16 anal rays, 15 to 19 branchiostegals, $23(9+14)$ gill-rakers on the anterior gill arch, and 140 to 185 pyloric cœca. The scales are comparatively large, there being from $\mathrm{I} 30$ to I 55 in a longitudinal series. In the spring the body is silvery, the back, dorsal fin, and caudal fin having more or less of round black spots, and the sides of the head having a peculiar tin-colored metallic lustre. In the fall the color is often black or dirty-red, and the species can then only be distinguished from the dog-salmon by its technical characters.

The Blue-back Salmon (Oncorhynchus nerka) usually weighs from 5 to 8 pounds. It has about I4 developed anal rays, I4 branchiostegals, and 75 to 95 pyloric cœca. The gill-rakers are more numerous than in any other salmon, the number being usually about $39(16+23)$. The scales are larger, there being $\mathrm{I} 30$ to $\mathrm{I} 4 \mathrm{O}$ in the lateral line. In the spring the form is plumply rounded, and the color is a clear bright blue above, silvery below, and everywhere immaculate. Young fishes often show a few round black spots, which disappear when they enter the sea. Fall specimens in the lakes are bright red in color, hook-nosed and slabsided, and bear little resemblance to the spring run. Young spawning male grilse are also peculiar in appearance, and were for a time considered as forming a distinct genus, under the name of "Hypsifario Kennerlyi." This species appears to be sometimes landlocked in mountain lakes, in 
which case it reaches but a small size. Such specimens, called "Kokos" by the Indians, have been sent us from Lake Whatcom, Washington Territory, by Mr. T. J. Smith of Whatcom.

The Silver Salmon (Oncorliynchus kisutch) reaches a weight of 3 to 8 pounds. It has 13 developed rays in the anal, 13 branchiostegals, 23 (IO $+\mathrm{I} 3$ ) gill-rakers, and 45 to 80 pyloric cœca. There are about 127 scales in the lateral line. In color, it is silvery in spring, greenish above, and with a few faint black spots on the upper parts only. In the fall the males are mostly of a dirty red.

The Dog Salmon (Oncorhynchus keta) reaches an average weight of about 12 pounds. It has about 14 anal rays, 14 branchiostegals, $24(9+15)$ gillrakers, and 140 to 185 pyloric cœca. There are about 150 scales in the lateral line. In spring it is dirty silvery, immaculate, or sprinkled with small black specks, the fins dusky. In the fall the male is brick-red or blackish, and its jaws are greatly distorted.

The Humpback Salmon (Oncorhynchus gorbuscha) is the smallest of the species, weighing from 3 to 6 pounds. It has usually 15 anal rays, I 2 branchiostegals, 28 ( $13+15)$ gill-rakers, and about 180 pyloric cœeca. Its scales are much smaller than in any other salmon, there being I 80 to 240 in the lateral line. In color it is bluish above, silvery below, the posterior and upper parts with many round black spots. The males in fall are red, and are more extravagantly distorted than in any other of the Salmonida.

Of these species the blue-back predominates in 
Frazer River, the silver salmon in Puget Sound, the quinnat in the Columbia and the Sacramento, and the silver salmon in most of the streams along the coast. All the species have been seen by us in the Columbia and in Frazer River; all but the blue-back in the Sacramento and in waters tributary to Puget Sound. Only the quinnat has been noticed south of San Francisco. Its range has been traced as far as Ventura River. Of these species, the quinnat and blue-back salmon habitually "run" in the spring; the others in the fall. The usual order of running in the rivers is as follows: nerka, tschawytscha, kisutch, gorbuscha, keta.

The economic value of the spring-running salmon is far greater than that of the other species, because they can be captured in numbers when at their best, while the others are usually taken only after deterioration. To this fact the worthlessness of Oncorhynchus keta as compared with the other species is probably wholly due.

The habits of the salmon in the ocean are not easily studied. Quinnat and silver salmon of all sizes are taken with the seine at almost any season in Puget Sound. This would indicate that these species do not go far from the shore. The quinnat takes the hook freely in Monterey Bay, both near the shore and at a distance of six to eight miles out. We have reason to believe that these two species do not necessarily seek great depths, but probably remain not very far from the mouth of the rivers in which they were spawned. The blue-back and the dog salmon probably seek deeper water, as the former is seldom or never taken with the 
seine in the ocean, and the latter is known to enter the Strait of Fuca at the spawning season, therefore coming in from the open sea. The great majority of the quinnat salmon, and nearly all the blue-back salmon enter the rivers in the spring. The run of both begins generally at the last of March; it lasts, with various modifications and interruptions, until the actual spawning season in November; the time of running and the proportionate amount in each of the subordinate runs varying with each different river. In general, the runs are slack in the summer and increase with the first high water of autumn. By the last of August only straggling blue-backs can be found in the lower course of any stream; but both in the Columbia and in the Sacramento the quinnat runs in considerable numbers at least till October. In the Sacramento the run is greatest in the fall, and more run in the summer than in spring. In the Sacramento and the smaller rivers southward, there is a winter run, beginning in December. The spring salmon ascends only those rivers which are fed by the melting snows from the mountains, and which have sufficient volume to send their waters well out to sea. Those salmon which run in the spring are chiefly adults (supposed to be at least three years old). Their milt and spawn are no more developed than at the same time in others of the same species which are not to enter the rivers until fall. It would appear that the contact with cold fresh water, when in the ocean, in some way causes them to run towards it, and to run before there is any special influence to that end exerted by the 
development of the organs of generation. High water on any of these rivers in the spring is always followed by an increased run of salmon. The salmon-canners think - and this is probably true that salmon which would not have run till later are brought up by the contact with the cold water. The cause of this effect of cold fresh water is not understood. We may call it an instinct of the salmon, which is another way of expressing our ignorance. In general, it seems to be true that in those rivers and during those years when the spring run is greatest, the fall run is least to be depended on.

As the season advances, smaller and younger salmon of these species (quinnat and blue-back) enter the rivers to spawn, and in the fall these young specimens are very numcrous. We have thus far failed to notice any gradations in size or appearance of these young fish by which their ages could be ascertained. It is, however, probable that some of both sexes reproduce at the age of one year. In Frazer River, in the fall, quinnat male grilse of every size, from eight inches upwards, were running, the milt fully developed, but usually not showing the hooked jaws and dark colors of the older males. Females less than eighteen inches in length were rare. All of either sex, large and small, then in the river, had the ovaries or milt developed. Little blue-backs of every size, down to six inches, are also found in the upper Columbia in the fall, with their organs of generation fully developed. Nineteen twentieths of these young fish are males, and some of them 
have the hooked jaws and red cclor of the old males.

The average weight of the quinnat in the Columbia, in the spring, is twenty-two pounds; in the Sacramento, about sixteen. Individuals weighing from forty to sixty pounds are frequently found in both rivers, and some as high as eighty or even one hundred pounds are recorded. It is questioned whether these large fishes are those which, of the same age, have grown more rapidly; those which are older, but have for some reason failed to spawn; or those which have survived one or more spawning seasons. All these origins may be possible in individual cases; we are, however, of the opinion that the majority of these large fishes are those which have hitherto run in the fall, and thus having spawned not far from the sea, have survived the spawning season of the previous year.

Those fish which enter the rivers in the spring continue their ascent till death or the spawning season overtakes them. Probably none of them ever return to the ocean, and a large proportion fail to spawn. They are known to ascend the Sacramento to its extreme head-waters, about four hundred miles. In the Columbia they ascend as far as the Bitter Root Mountains and at least to the Spokane Falls, and their extreme limit is not known. This is a distance of six to eight hundred miles. At these great distances, when the fish have reached the spawning grounds, besides the usual changes of the breeding season, their bodies are covered with bruises, on which patches of white fungus develop. The fins become 
mutilated, their eyes are often injured or destroyed, parasitic worms gather in their gills, they become extremely emaciated, their flesh becomes white from the loss of oil; and as soon as the spawning - act is accomplished, and sometimes before, all of them die. The ascent of the Cascades and the Dalles probably causes the injury or death of a great many salmon.

When the salmon enter the river they refuse to take bait, and their stomachs are always found empty and contracted. In the rivers they do not feed; and when they reach the spawning grounds, their stomachs, pyloric cœca and all, are said to be no larger than one's finger. They will sometimes take the fly, or a hook baited with salmon roe, in the clear waters of the upper tributaries, but there is no other evidence known to us that they feed when there. Only the quinnat and blue-back (there called red-fish) have been found at any great distance from the sea, and these (as adult fishes) only in late summer and fall.

The spawning season is probably about the same for all the species. It varies for each of the different rivers, and for different parts of the same river. It doubtless extends from July to December. The manner of spawning is probably similar for all the species, but we have no data for any except the quinnat. In this species the fishes pair off; the male, with tail and snout, excavates a broad, shallow " nest" in the gravelly bed of the stream, in rapid water, at a depth of one to four feet; the female deposits her eggs in it, and after the exclusion of the milt, they cover them with stones and 
gravel. They then float down the stream tail foremost. As already stated, a great majority of them die. In the head-waters of the large streams, unquestionably, all die; in the small streams, and near the sea, an unknown percentage probably survive. The young hatch in about sixty days, and most of them return to the ocean during the high water of the spring.

The salmon of all kinds in the spring are silvery, spotted or not according to the species, and with the mouth about equally symmetrical in both sexes. As the spawning season approaches, the female loses her silvery color, becomes more slimy, the scales on the back partly sink into the skin, and the flesh changes from salmon red and becomes variously paler, from the loss of oil; the degree of paleness varying much with individuals and with inhabitants of different rivers. In the Sacramento the flesh of the quinnat, in either spring or fall, is rarely pale. In the Columbia a few with pale flesh are sometimes taken in spring, and a good many in the fall. In Frazer River the fall run of the quinnat is nearly worthless for canning purposes, because so many are "white-meated." In the spring very few are "white-meated;" but the number increases towards fall, when there is every variation, some having red streaks running through them, others being red toward the head and pale toward the tail. The red and pale ones cannot be distinguished externally, and the color is dependent on neither age nor sex. There is said to be no difference in the taste, but there is no market for canned salmon not of the conventional orange-color. 
As the season advances, the difference between the males and females becomes more and more marked, and keeps pace with the development of the milt, as is shown by dissection. The males have (I) the premaxillaries and the tip of the lower jaw more and more prolonged, both of the jaws becoming finally strongly and often extravagantly hooked, so that either they shut by the side of each other like shears, or else the mouth cannot be closed. (2) The front teeth become very long and canine-like, their growth proceeding very rapidly, until they are often half an inch long. (3) The teeth on the vomer and tongue often disappear. (4) The body grows more compressed and deeper at the shoulders, so that a very distinct hump is formed; this is more developed in Oncorhynchus gorbuscha, but is found in all. (5) The scales disappear, especially on the back, by the growth of spongy skin. (6) The color changes from silvery to various shades of black and red, or blotchy, according to the species. The blue-back turns rosy red, the dog salmon a dull blotchy red, and the quinnat generally blackish. The distorted males are commonly considered worthless, rejected by the canners and salmon-salters, but preserved by the Indians. These changes are due solely to influences connected with the growth of the reproductive organs. They are not in any way due to the action of fresh water. They take place at about the same time in the adult males of all species, whether in the ocean or in the rivers. At the time of the spring runs all are symmetrical. In the fall all males, of whatever species, are more or less distorted. 
Among the dog salmon, which run only in the fall, the males are hook-jawed and red-blotched when they first enter the Strait of Fuca from the outside. The humpback, taken in salt water about Seattle, have the same peculiarities. The male is slabsided, hook-billed, and distorted, and is rejected by the canners. No hook-jawed females of any species have been seen. It is not positively known that any fully hook-jawed male survives the reproductive act. If any do, the jaws must resume the normal form.

On first entering a stream the salmon swim about as if playing. They always head towards the current, and this appearance of playing may be simply due to facing the moving tide. Afterwards they enter the deepest parts of the stream and swim straight up, with few interruptions. Their rate of travel at Sacramento is estimated by Stone at about two miles per day; on the Columbia at about three miles per day. Those who enter the Columbia in the spring and ascend to the mountain rivers of Idaho, must go at a more rapid rate than this, as they must make an average of nearly four miles per day.

As already stated, the economic value of any species depends in great part on its being a "spring salmon." It is not generally possible to capture salmon of any species in large numbers until they have entered the rivers, and the spring salmon enter the rivers long before the growth of the organs of reproduction has reduced the richness of the flesh. The fall salmon cannot be taken in quantity until their flesh has deteriorated; hence 
the dog salmon is practically almost worthless, except to the Indians, and the humpback salmon is little better. The silver salmon, with the same breeding habits as the dog salmon, is more valuable, as it is found in the inland waters of Puget Sound for a considerable time before the fall rains cause the fall runs, and it may be taken in large numbers with seines before the season for entering the rivers. The quinnat salmon, from its great size and abundance, is more valuable than all the other fishes on our Pacific coast taken together. The blueback, similar in flesh, but much smaller and less abundant, is worth much more than the combined value of the three remaining species of salmon.

The fall salmon of all species, but especially of the dog salmon, ascend streams but a short distance before spawning. They seem to be in great anxiety to find fresh water, and many of them work their way up little brooks only a few inches deep, where they perish miserably, floundering about on the stones. Every stream, of whatever kind, has more or less of these fall salmon.

It is the prevailing impression that the salmon have some special instinct which leads them to return to spawn in the same spawning grounds where they were originally hatched. We fail to find any evidence of this in the case of the Pacific coast salmon, and we do not believe it to be true. It seems more probable that the young salmon hatched in any river mostly remain in the ocean within a radius of twenty, thirty, or forty miles of its mouth. These, in their movements about in the ocean, may come into contact with the cold 
waters of their parent rivers, or perhaps of any other river, at a considerable distance from the shore. In the case of the quinnat and the blueback, their "instinct" seems to lead them to ascend these fresh waters, and in a majority of cases these waters will be those in which the fishes in question were originally spawned. Later in the season the growth of the reproductive organs leads them to approach the shore and search for fresh waters, and still the chances are that they may find the original stream. But undoubtedly many fall salmon ascend, or try to ascend, streams in which no salmon was ever hatched. In little brooks about Puget Sound, where the water is not three inches deep, are often found dead or dying salmon, which have entered them for the purpose of spawning. It is said of the Russian River and other California rivers, that their mouths, in the time of low water in summer, generally become entirely closed by sand-bars, and that the salmon, in their eagerness to ascend them, frequently fling themselves entirely out of water on the beach. But this does not prove that the salmon are guided by a marvellous geographical instinct which leads them to their parent river in spite of the fact that the river cannot be found. The waters of Russian River soak through these sand-bars, and the salmon instinct, we think, leads them merely to search for fresh waters. This matter is much in need of further investigation; at present, however, we find no reason to believe that the salmon enter the Rogue River simply because they were spawned there, or that a salmon hatched in the Clackamas 
River is more likely, on that account, to return to the Clackamas than to go up the Cowlitz or the Des Chûtes. "At the hatchery on Rogue River, the fish are stripped, marked, and set free, and every year since the hatchery has been in operation some of the marked fish have been re-caught. The young fry are also marked, but none of them have been re-caught." The shad is another species of fish supposed to possess this remarkable homing instinct. Shad have been planted in the Sacramento River, and considerable numbers descended from this plant have been already taken in the Columbia River and in Monterey Bay, but not a single one, so far as known to me, in the original stream, the Sacramento.

In regard to the diminution of the number of salmon on the coast we may make these observations. In Puget Sound, Frazer River, and the small streams, there appears to be little or no evidence of diminution. In the Columbia River the evidence appears somewhat conflicting. The catch in I 880 was considerably greater than ever before (nearly 540,000 cases of 48 pounds each having been packed), although the fishing for three or four years has been very extensive. On the other hand, the high water of that year undoubtedly caused many fish to become spring salmon which would otherwise have run in the fall. Moreover, it is urged that a few years ago, when the number caught was about half as great as in 1880 , the amount of netting used was perhaps one eighth as much. With a comparatively small outfit the canners caught half the fish; now, with nets much 
larger and more numerous, they catch them nearly all, scarcely any escaping during the fishing season (April I to August I). Whether an actual reduction in the number of fish running can be proved or not, there can be no question that the present rate of destruction of the salmon will deplete the river before many years. A considerable number of quinnat salmon run in August and September, and some stragglers even later; these are all which now keep up the supply of fish in the river. The non-molestation of this fall run, therefore, does something to atone for the almost total destruction of the spring run. This, however, is insufficient. A well-ordered salmon hatchery is the only means by which the destruction of the salmon fisheries of the Columbia River can be prevented.

The fact that the humpback salmon runs only on alternate years in Puget Sound (I875, I877, 1879, etc.) is well attested and at present unexplained. Stray individuals only are taken in other years. This species has a distinct run in the United States in Puget Sound only, although individuals (called "lost salmon") are occasionally taken in the Columbia and in the Sacramento.

Numerous attempts have been made to introduce the quinnat salmon into the waters of the Eastern States and of Europe. Individuals thus planted have been taken in several different localities, but as yet not in any considerable number.

The genus Salmo comprises those forms of salmon and trout which have been longest known. As in related genera, the mouth is large, and the jaws, palatines, and tongue are armed with strong 
teeth. The vomer is flat, its shaft not depressed below the level of the head or chevron (the anterior end). There are a few teeth on the chevron; and behind it, on the shaft, there is either a double series of teeth or an irregular single series. These teeth in the true salmon disappear with age, but in the others (the black-spotted trout) they are persistent. The scales are silvery, and moderate or small in size. There are 9 to I I developed rays in the anal fin. The caudal fin is truncate, or variously concave or forked. There are usually 40 to 70 pyloric cœca, II or I 2 branchiostegals, and about $20(8+12)$ gill-rakers. The sexual peculiarities are in general less marked than in Oncorhynchus; they are also greater in the anadromous species than in those which inhabit fresh waters. In general, the male in the breeding season is redder, its jaws are prolonged, the front teeth enlarged, the lower jaw turned upwards at the end, and the upper jaw notched, or sometimes even perforated, by the tip of the lower. All the species of Salmo (like those of Oncorhynchus) are more or less spotted with black.

Two species (salmon) are marine and anadromous, taking the place in the North Atlantic occupied in the North Pacific by the King Salmon or species of Oncorhynchus. The others (trout), forming the sub-genus Salar, are non-migratory, or at least irregularly or imperfectly anadromous. They abound in all streams of northern Europe, northern Asia, and in that part of North America which lies west of the Mississippi Valley. The blackspotted trout are entircly wanting in eastern 
America, - a remarkable fact in geographical distribution, perhaps explained only on the hypothesis of the comparatively recent and Eurasiatic origin of the group, which, we may suppose, has not yet had opportunity to extend its range across the plains, unsuitable for salmon life, which separate the upper Missouri from the Great Lakes.

The Salmon (Salmo salar) is the only blackspotted salmonoid found in American waters tributary to the Atlantic. In Europe, where other species similarly colored occur, the species may be best distinguished by the fact that the teeth on the shaft of the vomer mostly disappear with age. From the only other species positively known (Salmo trutta) which shares this character, the true salmon may be distinguished by the presence of but eleven scales between the adipose fin and the lateral line, while Salmo trutta has about fourteen. The scales are comparatively large in the salmon, there being about one hundred and twenty-five in the lateral line. The caudal fin, which is forked in the young, becomes, as in other species of salmon, more or less truncate with age. The pyloric cœca are fifty to sixty in number.

The following account of the coloration of the salmon is from Dr. Day's "Fishes of Great Britain : " -

"Color in adults superiorly of a steel blue, becoming lighter on the sides and beneath. Mostly a few rounded or $x$-shaped spots scattered above the lateral line and upper half of the head, being more numerous in the female than in the male. Dorsal, caudal, and pectoral fins dusky; ventrals and anal white, the former grayish 
internally. Prior to entering fresh waters these fish are of a brilliant steel blue along the back, which becomes changed to a muddy tinge when they enter rivers. After these fish have passed into the fresh waters for the purpose of breeding, numerous orange streaks appear in the cheeks of the male, and also spots or even marks of the same, and likewise of a red color, on the body. It is now termed a 'red-fish.' The female, however, is dark in color, and known as 'black-fish.' 'Smolts' (young river fish) are bluish along the upper half of the body, silvery along the sides, due to a layer of silvery scales being formed over the trout-like colors, while they have darker fins than the yearling 'pink;' but similar bands and spots, which can be seen (as in the parr) if the example be held in certain positions of light. 'Parr' (fishes of the year) have two or three black spots only on the opercle, and black spots and also orange ones along the upper half of the body, and no dark ones below the lateral line, although there may be orange ones which can be seen in its course. Along the side of the body are a series ( 12 to 15) of transverse bluish bands, wider than the ground color and crossing the lateral line, while in the upper half of the body the darker color of the back forms an arch over each of these bands, a row of spots along the middle of the rayed dorsal fin and the adipose orange-tipped."

The dusky cross-shades found in the young salmon or parr are characteristic of the young of nearly all the Salmonida.

The salmon of the Atlantic is, as already stated, an anadromous fish, spending most of its life in the sea, and entering the streams in the fall for the purpose of reproduction. The time of running varies much in different strcams and also in different countries. As with the Pacific specics, these 
salmon are not easily discouraged in their progress, leaping cascades and other obstructions, or, if these prove impassable, dying after repeated fruitless attempts.

The young salmon, known as the "parr," is hatched in the spring. It usually remains about two years in the rivers, descending at about the third spring to the sea, when it is known as "smolt." In the sea it grows much more rapidly, and becomes more silvery in color, and is known as "grilse." The grilse rapidly develop into the adult salmon; and some of them, as is the case with the grilse of the Pacific salmon, are capable of reproduction.

After spawning the salmon are very lean and unwholesome in appearance, as in fact. They are then known as "kelts." The Atlantic salmon does not ascend rivers to any such distances as those traversed by the quinnat and the blue-back. Its kelts, therefore, for the most part survive the act of spawning. Dr. Day thinks that they feed upon the young salmon in the rivers, and that, therefore, the destruction of the kelts might increase the supply of salmon.

As a food-fish, the Atlantic salmon is very similar to the Pacific species, neither better nor worse, so far as I can sec, when equally fresh. In both the flesh is rich and finely flavored; but the appetite of man becomes cloyed with salmon-flesh sooner than with that of whitefish, smelt, or charr. In size, the Atlantic salmon does not fall far short of the quinnat. The average weight of the adult is probably less than 
fifteen pounds. The largest one of which I find a record was taken on the coast of Ireland in I88I, and weighed eighty-four and three-fourths pounds.

The salmon is found in Europe between the latitude of $45^{\circ}$ and $75^{\circ}$. In the United States it is now rarely seen south of Cape Cod, although formerly the Hudson and numerous other rivers were salmon streams. Over-fishing, obstructions in the rivers, and pollution of the water by manufactories and by city sewage are agencies against which the salmon cannot cope.

Seven species of salmon (as distinguished from trout) are recognized by Dr. Günther in Europe, and three in America. The landlocked forms, abundant in Norway, Sweden, and Maine, which cannot, or at least do not, descend to the sea, are regarded by him as distinct species. "The question," observes Dr. Günther, "whether any of the migratory species can be retained by artificial means in fresh water, and finally accommodate themselves to a permanent sojourn therein, must be negatived for the present." On this point I am compelled to disagree with Dr. Günther. I have compared numerous specimens of the common landlocked salmon (Salmo salar sebago) of the lakes of Maine and New Brunswick with landlocked salmon (Salmo salar hardini) from the lakes of Sweden, and with numerous migratory salmon, both from America and Europe. I can have no hesitation in regarding them all as specifically identical. The differences are very trivial in kind, and not greater than would be expected on 
the hypothesis of recent adaptation of the salmon to lake-life. We have, therefore, on our Atlantic coast but one species of salmon, Salmo salar. Dr. Francis Day, who has very thoroughly studied these fishes, takes, in his memoir on "The Fishes of Great Britain and Ireland," and in other papers, a similar view in regard to the European species. Omitting the species with permanent teeth on the shaft of the vomer (sub-genus Salar), he finds among the salmon proper only two species, Salmo salar and Salmo trutta. The latter species, the sea-trout or salmon-trout of England, is similar to the salmon in many respects, but has rather smaller scales, there being fourteen in an oblique series between the adipose fin and the lateral line. It is not so strong a fish as the salmon, nor does it reach so large a size. Although naturally anadromous, like the true salmon, landlocked forms of the salmon-trout are not uncommon. These have been usually regarded as different species, while aberrant or intermediate individuals are usually regarded as hybrids.

The present writer has examined many thousands of American Salmonida, both of Oncorhynchus and Salmo. While many variations have come to his attention, and he has been compelled more than once to modify his views as to specific distinctions, he has never yet seen an individual which he had the slightest reason to regard as a "hybrid." It is evident that in America but few species of salmonoids exist, and that these are subject to many variations. It is certainly illogical to conclude that every specimen which does not 
correspond to our closet-formed definition of its species must therefore be a "hybrid" with some other. There is no evidence worth mentioning, known to me, of extensive hybridization in a state of nature in any group of fishes. This matter is much in need of further study; for what is true of the species in one region, in this regard, may not be true of others. The species of trout, also, may perhaps hybridize, while Salmo salar and the species of Oncorhynchus certainly do not. Dr. Günther observes : -

"Johnson, a correspondent of Willughby, had already expressed his belief that the different salmonoids interbreed; and this view has since been shared by many who have observed these fishes in Nature. Hybrids between the sewin (Salmo trutta cambricus) and the river-trout (Salmo fario) were numerous in the Rhymney and other rivers of South Wales before salmonoids were almost exterminated by the pollutions allowed to pass into these streams, and so variable in their characters that the passage from one species to the other could be demonstrated in an almost unbroken series, which might induce some naturalists to regard both species as identical. Abundant evidence of a similar character has accumulated, showing the frequent occurrence of hybrids between Salmo fario and $S$. trutta. . . In some rivers the conditions appear to be more favorable to hybridism than in others, in which hybrids are of comparatively rare occurrence. Hybrids between the salmon and other species are very scarce everywhere."

The black-spotted trout, forming the sub-genus Salar, differ from Salmo salar and Salmo trutta in the greater development of the vomerine teeth, 
which are persistent throughout life, in a long double series on the shaft of the vomer. About seven species are laboriously distinguished by Dr. Günther, in the waters of western Europe. Most of these are regarded by Dr. Day as varieties of Salmo fario. The latter species, the common river-trout or lake-trout of Europe, is found throughout northern and central Europe, wherever suitable waters occur. It is abundant, gamy, takes the hook readily, and is excellent as food. It is more hardy than the different species of charr, although from an æsthetic point of view it must be regarded as inferior to all of the Salvelini. The largest river-trout recorded by Dr. Day weighed twenty-one pounds. Such large individuals are usually found in lakes in the north, well stocked with smaller fishes on which trout may feed. Farther south, where the surroundings are less favorable to trout-life, they become mature at a length of less than a foot, and a weight of a few ounces. These excessive variations in the size of individuals have received too little notice from students of Salmonide. Similar variations occur in all the non-migratory species of Salmo and of Salvelinus. Numerous river-trout have been recorded from northern Asia, but as yet nothing can be definitely stated as to the number of species actually existing.

In North America, only the region west of the Mississippi Valley, and the valley of Mackenzie River, have species of black-spotted trout. If we are to follow the usage of the names "salmon" and " trout," which prevails in England, we should 
say that it is only these Western regions which have any trout at all. Of the number of species (about twenty in all) which have been indicated by authors, certainly not more than four can possibly be regarded as distinct species; and of these four, two are, as will be seen, still extremely doubtful. The other names are either useless synonymes, or else they have been applied to local varieties which pass by degrees into the ordinary types.

Of the American species the Rainbow Trout (Salmo irideus) most nearly approaches the European Salmo fario. It has the scales comparatively large, although rather smaller than in Salmo fario, the usual number in a longitudinal series being about 135. The mouth is smaller than in other American trout; the maxillary, except in old males, rarely extending beyond the eye. The. caudal fin is well forked, becoming in very old fishes more nearly truncate. The color, as in all the other species, is bluish, the sides silvery in the males, with a red lateral band, and reddish and dusky blotches. The head, back, and upper fins are sprinkled with round black spots, which are very variable in number. In specimens taken in the sea, this species, like most other trout in similar conditions, is bright silvery, and sometimes immaculate. This species is especially characteristic of the waters of California. It abounds in every clear brook, from the Mexican line northward to Mount Shasta, and occasionally in coastwise streams to Alaska. No specimens have been anywhere obtained to the eastward of the Cascade 
Range or of the Sierra Nevada. It varies much in size; specimens from northern California often reach a weight of six pounds, while in the Rio San Luis Rey, the southernmost locality from which I have obtained trout, they seldom exceed a length of six inches. Although not an anadromous species, the rainbow trout frequently moves about in the rivers, and it often enters the sea. Several attempts have been made to introduce it in Eastern streams. It is apparently more hardy and less greedy than the American Charr, or Brook Trout (Salvelimus fontinalis). On the other hand, it is distinctly inferior to the latter in beauty and in gaminess.

The Steel-head (Salmo gairdneri) is a large trout, of twelve to twenty pounds in weight, found very abundantly in the mouth of the Columbia and other rivers, in the spring, at the time of the early salmon run. These are evidently spent fishes. This fact would indicate a spawning time later (probably midwinter) than that of the salmon, and their occurrence in the river at the salmon run is evidently due to a return toward the sea. Steel-heads are occasionally taken in the Sacramento, but in the Columbia they are abundant. They are rejected by the salmon fishermen, as their flesh is pale, and the bones are much more firmly ossified than in the species of Oncorhynchus. The soft characters of the bones in the latter group, as compared with those of the larger trout, is one feature of their excellence as food, especially in the canned condition.

Comparing the steel-heads with the rainbow 
trout, we find no differences, other than that the former is of much larger size, and has a larger mouth, and its caudal fin is truncate instead of forked. But the tail becomes more truncate, and the mouth larger with age in all species of salmon and trout. If a rainbow trout were to reach the size of the steel-head, it ought to acquire characters similar to those of the latter species. Conversely, unless the rainbow trout are young of the steel-head, the young of the latter are unknown. It is my belief that the steel-head is simply the large rainbow trout which has lived in the sea, and ascends the river to spawn. If this be true, Salmo irideus must be omitted from our lists, as identical with Salmo gairdneri, the latter name being the earlier one.

The most widely distributed, and decidedly the most important, of the American black-spotted. trout is the Salmo mykiss (= Salmo purpuratis and clarki of authors), or, as we call it, the Redthroated Trout. This species has much smaller scales than the rainbow trout or steel-head, the usual number in a longitudinal series being 150 to I70. Its mouth is proportionately larger, and there is usually a narrow band of small teeth on the hyoid bone at the base of the tongue. These teeth are always wanting in Salmo irideus and gairdneri. The color in Salmo mykiss is, as in other species, excessively variable. In almost all specimens there is a deep-red blotch on the throat, between the branches of the lower jaw and the membrane connecting them. This I have not found in other species; and as it seems to be 
constant in all varieties of Salmo mykiss, at all ages, it will furnish a good distinctive character. The red-throated trout is found in every suitable river and lake in the great basin of Utah, in the streams of Colorado, Wyoming, and Montana, on both sides of the Rocky Mountains. It is also found throughout Oregon, Washington, Idaho, British Columbia, and Alaska, probably no stream or lake suitable for salmonoid life being without it. In California the species seems to be comparatively rare, and its range has not been well made out. Large sea-run individuals apparently analogous to the steel-heads are sometimes found in the mouth of the Sacramento. In Washington Territory and Alaska this species regularly enters the sea. In Puget Sound it is a common fish. These sea-run individuals are more silvery and less spotted than those found in the mountain streams and lakes. Numerous more or less tangible varieties of Salmo mykiss occur, one of the most marked of which is the beautiful trout (Salmo mykiss henshawi) found in Lake Tahoe, the finest of all the mountain lakes of the Sierra Nevada. The size of Salmo mykiss is subject to much variation. Ordinarily, four to six pounds is a large size; but in certain favored waters, as Lake Tahoe, and the fjord bays of the Northwest, specimens from twenty to thirty pounds are occasionally taken. No attempt has been made (1880) to transport this, the finest known species of black-spotted trout, to Eastern waters. The writer thinks it much worthier of experiment, in this regard, than the rainbow trout. The great variety of the waters in which it occurs 
seems to promise a ready adaptation to other surroundings.

The Rio Grande Trout (Salmo mykiss spilurus) is a large and profusely spotted trout, found in the head-waters of the Rio Grande, the mountain streams of the great basin of Utah, and as far south as the northern part of Chihuahua. Its scales are still smaller than those of the redthroated trout, to which it bears much resemblance, and of which it is probably simply a local variety.

The genus Hucho has been framed for the Huchen or Rothfisch (Hucho hucho) of the Danube, - a large salmon, differing from the genus Salmo in having no teeth on the shaft of the vomer, and from the Salvelini at least in form and coloration. The real characters of the genus, which seems to be distinct from Salvelinus, have not yet been worked out. The Huchen is a long and slender, somewhat pike-like fish, with depressed snout and strong teeth. The color is silvery, sprinkled with small black dots. It reaches a size little inferior to that of the salmon, and it is said to be an excellent food-fish. Little is known of its habits. It has, however, the reputation of being unusually voracious for a salmon.

The genus Salvelinus comprises the finest of the Salmonide, from the point of view of the angler or the artist. In England the species are known as charr, in contradistinction to the black-spotted species of Salmo, which are called trout. The former name has unfortunately been lost in America, where the name "trout" is given indiscrimi- 
nately to both groups, and, still worse, to numerous other fishes (Cestreus, Micropterus, Hexagrammus) wholly unlike the Salmonida in all respects. It is sometimes said that the "American brook-trout is no trout, nothing but a charr," almost as though " charr" were a word of reproach. Nothing higher, however, can be said of a salmonoid than that it is a "charr." The technical character of the genus Salvelinus lies in the form of its vomer. This is deeper than in Salmo; and when the flesh is removed the bone is found to be somewhat boatshaped above, and with the shaft depressed and out of the line of the chevron. Only the chevron is armed with teeth, and the shaft is covered by skin. In one species (S. namaycush) the chevron sends a projection backward which bears teeth; these teeth appearing, unless the flesh is removed, as if standing on the shaft of the bone.

In color all the charrs differ from the salmon and trout. The body in all is covered with round spots which are paler than the ground color, and crimson or gray. The lower fins are usually edged with bright colors. The sexual differences are not great. The scales, in general, are smaller than in other Salmonida, and they are imbedded in the skin to such a degree as to escape the notice of casual observers and even of most anglers.

"One trout scale in the sca'es I 'd lay
(If trout had scales), and 't will outweigh
The wrong side of the balances."

LOWELL.

The charrs inhabit, in general, only the clearest and coldest of mountain streams and lakes. They 
are not migratory, or only to a limited extent. In northern regions they descend to the sea, where they grow much more rapidly, and assume a nearly uniform silvery-gray color. The different species are found in all suitable waters throughout the northern parts of both continents, except in the Rocky Mountains and Great Basin, where only the black-spotted trout occur. The number of species of charr is very uncertain, as, both in America and Europe, trivial variations and individual peculiarities have been raised to the rank of species. More types, however, seem to be represented in America than in Europe.

The only really well-authenticated species of charr in European waters is the Red Charr, Sälbling, or Ombre Chevalier (Salvelinus alpinus). This species is found in cold clear streams in Switzerland, Germany, and throughout Scandina-via and the British Islands. Compared with the American charr or brook-trout, it is a slenderer fish, with smaller mouth, longer fins, and smaller red spots, which are confined to the sides of the body. It is a "gregarious and deep-swimming fish, shy of taking the bait and feeding largely at nighttime. It appears to require very pure and mostly deep water for its residence." It is less tenacious of life than the trout. It reaches a weight of from one to five pounds, probably rarely exceeding the latter in size. The various charr described from Siberia are far too little known to be enumerated here.

Of the American charr the one most resembling the European species is the Rangeley Lake Trout 
(Salvelinus stagnalis). The exquisite little fish is known in the United States only from the Rangeley chain of lakes in western Maine. Quite lately specimens of what appears to be the same species have been taken in Arctic America, about Cumberland Gulf. Still later, Dr. T. H. Bean has shown its identity with the Greenland charr. Whether the species still inhabits any intervening waters is unknown. The Rangeley trout is much slenderer than the common brook-trout, with much smaller head and smaller mouth. In life it is dark blue above, and the deep red spots are confined to the sides of the body. The species rarely exceeds the length of a foot in the Rangeley Lakes, but in some other waters it reaches a much larger size. So far as is known it keeps itself in the depths of the lake until its spawning season approaches, in October, when it ascends the stream to spawn.

Another beautiful little charr, allied to Salvelinus stagnalis, is the Floeberg Charr (Salvelinus arcturus). This species has been brought from Victoria Lake and Floeberg Beach, in the extreme northern part of Arctic America, the northernmost point whence any salmonoid has been obtained.

The American Charr, or, as it is usually called, the Brook Trout (Salvelinus fontinalis), although one of the most beautiful of fishes, is perhaps the least graceful of all the genuine charrs. It is technically distinguished by the somewhat heavy head and large mouth, the maxillary bone reaching more or less beyond the eye. There are no teeth on the hyoid bone, traces at least of such teeth being found in nearly all other species. Its color is 
somewhat different from that of the others, the red spots being large and the back more or less mottled and barred with darker olive. The dorsal and caudal fins are likewise barred or mottled, while in the other species they are generally uniform in color. The brook-trout is found only in streams east of the Mississippi and Saskatchewan. It occurs in all suitable streams of the Alleghany region and the Great Lake system, from the Chattahoochee River in northern Georgia northward at least to Labrador and Hudson Bay, the northern limits of its range being as yet not well ascertained. It varies greatly in size, according to its surroundings, those found in lakes being larger than those resident in small brooks. Those found farthest south, in the head-waters of the Chattahoochee, Savannah, Catawba, and French Broad, rarely pass the dimensions of fingerlings. The largest specimens are recorded from the sea along the Canadian coast. These frequently reach a weight of ten pounds; and from their marine and migratory habits, they may be regarded as forming a distinct variety ( $\mathrm{Sal}$ velinus fontinalis immaculatus). The largest freshwater specimens rarely exceed seven pounds in weight. Some unusually large brook-trout have been taken in the Rangeley lakes, the largest known to me having a reputed weight of eleven pounds. The brook-trout is the favorite game-fish of American waters, pre-eminent in wariness, in beauty, and in delicacy of flesh. It inhabits all clear and cold waters within its range, the large lakes and the smallest ponds, the tiniest brooks and the largest rivers; and when it can do so without soiling its 
aristocratic gills on the way, it descends to the sea and grows large and fat on the animals of the ocean. Although a bold biter it is a wary fish, and it often requires much skill to capture it. It can be caught too with artificial or natural flies, minnows, crickets, worms, grasshoppers, grubs, the spawn of other fish, or even the eyes or cut pieces of other trout. It spawns in the fall, from September to late in November. It begins to reproduce at the age of two years, then having a length of about six inches. In spring-time the trout delight in rapids and swiftly running water; and in the hot months of midsummer they resort to deep, cool, and shaded pools. Later, at the approach of the spawning season, they gather around the mouths of cool, gravelly brooks whither they resort to make their beds. ${ }^{1}$

The trout are rapidly disappearing from our streams through the agency of the manufacturer and the summer-boarder. In the words of an excellent angler, Rev. Myron W. Reed, -

"This is the last generation of trout-fishers. The children will not be able to find any. Already there are well-trodden paths by every stream in Maine, in New York, and in Michigan. I know of but one river in North America by the side of which you will find no paper collar or other evidence of civilization. It is the Nameless River. Not that trout will cease to be. They will be hatched by machinery and raised in ponds, and fattened on chopped liver, and grow flabby and lose their spots. The trout of the restaurant will not cease to be. $\mathrm{He}$ is no more like the trout of the wild river than the fat and songless reed-

1 Hallock. 
bird is like the bobolink. Gross feeding and easy pond life enervate and deprave him. The trout that the children will know only by legend is the gold-springled living arrow of the white water; able to zigzag up the cataract; able to loiter in the rapids; whose dainty meat is the glancing butterfly."

The brook-trout adapts itself readily to cultivation in artificial ponds. It has been successfully transported to Europe, and is already abundant in certain streams in England and elsewhere.

The "Dolly Varden" Trout (Salvelinus malma) is very similar to the brook-trout, closely resembling it in size, form, color, and habits. It is found in the streams of northern California, Oregon, Washington, British Columbia, Alaska, and Kamtschatka, mostly to the westward of the Cascade Range. It often enters the sea, and specimens of eleven pounds' weight have been obtained by the writer in Puget Sound. The Dolly Varden trout is, in general, deeper in body, and less compressed than the Eastern brook-trout. The red spots are found on the back of the fish as well as on the sides, and the back and upper fins are without the marblings and blotches seen in Salvelinus fontinalis. In value as food, in beauty, and in gaminess, Salvelinus malma is very similar to its Eastern cousin.

Allied to the true charrs, and now placed by us with them in the genus Salvelinus, is the Great Lake Trout, otherwise known as Mackinaw Trout, Longe, or Togue (Salvelinus namaycush). Technically, this fish differs from the true charrs in having on its vomer a raised crest behind the chevron, and 
free from the shaft. This crest is armed with strong teeth. There are also large hooked teeth on the hyoid bone, and the teeth generally are proportionately stronger than in most of the other species. The great lake-trout is grayish in color, light or dark according to its surroundings; and the body is covered with round paler spots, which are gray instead of red. The dorsal and caudal fins are marked with darker reticulations, somewhat as in the brook-trout. The great lake-trout is found in all the larger lakes from New England and New York to Wisconsin, Montana, and Alaska. It reaches a much larger size than any other Salvelinus, specimens of from fifteen to twenty pounds' weight being not uncommon, while it occasionally attains a weight of fifty to eighty pounds. As a food-fish it ranks high, although it may be regarded as somewhat inferior to the brook-trout or the white-fish. Compared with other salmonoids, the great lake-trout is a sluggish, heavy, and ravenous fish. It has been known to eat raw potato, liver, and corn-cobs, - refuse thrown from passing steamers. According to Herbert, " a coarse, heavy, stiff rod, and a powerful oiled hempen or flaxen line, on a winch, with a heavy sinker; a cod-hook, baited with any kind of flesh, fish, or fowl, - is the most successful, if not the most orthodox or scientific, mode of capturing him. His great size and immense strength alone give him value as a fish of game; but when hooked, he pulls strongly and fights hard, though he is a boring, deep fighter, and seldom if ever leaps out of the water, like the true salmon or brook-trout." 
In the depths of Lake Superior is a variety of the great lake-trout known as the Siscowet (Salvelinus namaycush siskazitz), remarkable for its extraordinary fatness of flesh. The cause of this difference lies probably in some peculiarity of food, as yet unascertained. 


\section{THE DISPERSION OF FRESH-WATER}

\section{FISHES.}

WHEN I was a boy and went fishing in the brooks of western New York, I noticed that the different streams did not always have the same kinds of fishes in them. Two streams in particular in Wyoming County, not far from my father's farm, engaged in this respect my special attention. Their sources are not far apart, and they flow in opposite directions, on opposite sides of a low ridge, - an old glacial moraine, something more than a mile across. The Oatka Creek flows northward from this ridge, while the East Coy runs toward the southeast on the other side of it, both flowing ultimately into the same river, the Genesee.

It does not require a very careful observer to see that in these two streams the fishes are not quite the same. The streams themselves are similar enough. In each the waters are clear and fed by springs. Each flows over gravel and clay, through alluvial meadows, in many windings, and with elms and alders "in all its elbows." In both streams we were sure of finding Trout, ${ }^{1}$ and in one of them the trout are still abundant. In both we used to catch the Brook Chub, ${ }^{2}$ or, as we called

1 Salvclinus fontinalis Mitchill.

${ }^{2}$ Semotilus atromaculatus Mitchill. 
it, the "Horned Dace;" and in both were large schools of Shiners ${ }^{1}$ and of Suckers. ${ }^{2}$ But in every deep hole, and especially in the mill-ponds along the East Coy Creek, the Horned Pout ${ }^{3}$ swarmed on the mucky bottoms. In every eddy, or in the deep hole worn out at the root of the elm-trees, could be seen the Sun-fish, ${ }^{4}$ strutting in green and scarlet, with spread fins keeping intruders away from its nest. But in the Oatka Creek were found neither Horned Pout nor Sun-fish, nor have I ever heard that either has been taken there. Then besides these nobler fishes, worthy of a place on every school-boy's string, we knew by sight, if not by name, numerous smaller fishes, Darters ${ }^{5}$ and Minnows, ${ }^{6}$ which crept about in the gravel on the bottom of the East Coy, but which we never recognized in the Oatka.

There must be a reason for differences like these, in the streams themselves or in the nature of the fishes. The Sun-fish and the Horned Pout are home-loving fishes to a greater extent than the others which I have mentioned; still, where no obstacles prevent, they are sure to move about. There must be, then, in the Oatka some sort of barrier, or strainer, which keeping these species back permits others more adventurous to pass; and a wider knowledge of the geography of the region showed that such is the case. Farther

1 Notropis megalops Rafinesque.

2 Catostomus teres Mitchill.

3 Ameiurus melas Rafinesque.

4 Lepomis gibbosus Linnæus.

5 Etheostoma flabcllari Rafinesque.-

6 Rhinichthys atronasus Mitchill. 
down in its course, the Oatka falls over a ledge of rock, forming a considerable waterfall at Rock Glen. Still lower down its waters disappear in the ground, sinking into some limestone cavern or gravel-bed, from which they reappear, after some six miles, in the large springs at Caledonia. Either of these barriers might well discourage a quietloving fish; while the trout and its active associates have sometime passed them, else we should not find them in the upper waters in which they alone form the fish-fauna. This problem is a simple one; a boy could work it out, and the obvious solution seems to be satisfactory.

Since those days I have been a fisherman in many waters, - not an angler exactly, but one who fishes for fish, and to whose net nothing large or small ever comes amiss; and wherever I go, I find cases like this.

We do not know all the fishes of America yet, nor all those well that we know by sight; still this knowledge will come with time and patience, and to procure it is a comparatively easy task. It is also easy to ascertain the more common inhabitants of any given stream. It is difficult, however, to obtain negative results which are really results. You cannot often say that a species does not live in a certain stream. You can only affirm that you have not yet found it there, and you can rarely fish in any stream so long that you can find nothing that you have not taken before. Still more difficult is it to gather the results of scattered observations into general statements regarding the distribution of fishes. The facts may be so few as to be 
misleading, or so numerous as to be confusing; and the few writers who have taken up this subject in detail have found both these difficulties to be serious. Whatever general propositions we may maintain must be stated with the modifying clause of "other things being equal;" and other things are never quite equal. Dr. Wilder's saying that "Nature abhors a generalization" is especially applicable to all discussions of the relations of species to environment.

Still less satisfactory is our attempt to investigate the causes on which our partial generalizations depend, - to attempt to break to pieces the "other things being equal" which baffle us in our search for general laws. Scarcely anything has been written on this phase of the subject from an American point of view. This little I have tried to include with my own observations, in preparing this paper. The same problems, of course, come up on each of the other continents and in all groups of animals or plants; but most that I shall say will be confined to the question of the dispersion of fishes in the fresh waters of North America. The broader questions of the boundaries of faunæ and of faunal areas I shall bring up only incidentally.

Some of the problems to be solved were first noticed by Professor Agassiz in 1850, in his work on Lake Superior. Later (1854), in a paper on the fishes of the Tennessee River, ${ }^{1}$ he makes the following statement:-

1 On Fishes from Tennessee River, Alabama. American Journal of Science and Arts, xvii. 2d series, 1854, p. 26. 
"The study of these features [of distribution] is of the greatest importance, inasmuch as it may eventually lead to a better understanding of the intentions implied in this seemingly arbitrary disposition of animal life. . . .

"There is still another very interesting problem respecting the geographical distribution of our fresh-water animals, which may be solved by the further investigation of the fishes of the Tennessee River. The water-course, taking the Powells, Clinch, and Holston Rivers as its head-waters, arises from the mountains of Virginia in latitude $37^{\circ}$; it then flows S. W. to latitude $34^{\circ} 25^{\prime}$, when it turns W. and N.W., and finally empties into the Ohio, under the same latitude as its source in $37^{\circ}$.

"The question now is this: Are the fishes of this water system the same throughout its extent? In which case we should infer that water communication is the chief condition of geographical distribution of our fresh-water fishes. Or do they differ in different stations along its course? And if so, are the differences mainly controlled by the elevation of the river above the level of the sea, or determined by climatic differences corresponding to differences of latitude? We should assume that the first alternative was true if the fishes of the upper course of the river differed from those of the middle and lower courses in the same manner as in the Danube, from its source to Pesth, where this stream flows nearly for its whole length under the same parallel. We would, on the contrary, suppose the second alternative to be well founded if marked differences were observed between the fish of such tracts of the river as do not materially differ in their elevation above the sea, but flow under different latitudes. Now, a few collections from different stations along this river, like that sent me by Dr. Newman from the vicinity of Huntsville, would settle at once this question, not for the Tennessee River alone, but for 
most rivers flowing under similar circumstances upon the surface of the globe. Nothing, however, short of such collections, compared closely with one another, will furnish a reliable answer. ... Whoever will accomplish this survey will have made a highly valuable contribution to our knowledge."

Certain conclusions were also suggested by Professor Cope in his excellent memoir on the fishes of the Alleghany region ${ }^{1}$ in 1868 . From this paper I make the following quotations:-

"The distribution of fresh-water fishes is of special importance to the questions of the origin and existence of species in connection with the physical conditions of the waters and of the land. This is, of course, owing to the restricted nature of their habitat, and the impossibility of their making extended migrations. With the submergence of land beneath the sea, fresh-water fish are destroyed in proportion to the extent of the invasion of salt water, while terrestrial vertebrates can retreat before it. Hence every inland fish-fauna dates from the last total submergence of the country.

"Prior to the elevation of a given mountain chain, the courses of the rivers may generally have been entirely different from their later ones. Subsequent to this period, they can only have undergone partial modifications. As subsequent submergences can rarely have extended to the highlands where such streams originate, the fishes of such rivers can only have been destroyed so far as they were unable to reach those elevated regions, and preserve themselves from destruction from salt water by sheltering themselves in mountain streams. On the other hand,

1 On the Distribution of Fresh-Water Fishes in the Alleghany Region of Southwestern Virginia. Journ. Acad. Nat. Sci., Phila., I868, pp. 207-247. 
a period of greater elevation of the land, and of consequent greater cold, would congeal the waters and cover their courses with glaciers. The fishes would be driven to the neighborhood of the coast, though no doubt in more southern latitudes a sufficient extent of uncongealed fresh waters would flow by a short course into the ocean, to preserve from destruction many forms of fresh-water fishes. Thus, through many vicissitudes, the fauna of a given system of rivers has had opportunity of uninterrupted descent, from the time of the elevation of the mountain range, in which it has its sources. . . .

"As regards the distinction of species in the disconnected basins of different rivers, which have been separated from an early geologic period, if species occur which are common to any two or more of them, the supporter of the theory of distinct creations must suppose that such species have been twice created, once for each hydrographic basin, or that waters flowing into the one basin have been transferred to another. The developmentalist, on the other hand, will accept the last proposition, or else suppose that time has seen an identical process and similar result of modification in these distinct regions.

"Facts of distribution in the eastern district of North America are these. Several species of fresh-water fishes occur at the same time in many Atlantic basins, from the Merrimac or from the Hudson to the James, and throughout the Mississippi Valley, and in the tributaries of the Great Lakes. On the other hand, the species of each river may be regarded as pertaining to four classes, whose distribution has direct reference to the character of the water and the food it offers: first, those of the tide-waters, of the river channels, bayous, and sluggish waters near them, or in the flat lands near the coast; second, those of the river channels of its upper course, 
where the currents are more distinct; third, those of the creeks of the hill country; fourth, those of the elevated mountain streams which are subject to falls and rapids."

Farther on in the same paper, Professor Cope reaches two important general conclusions, thus stated by him:-

"I. That species not generally distributed exist in waters on different sides of the great water-shed.

"II. That the distribution of the species is not governed by the outlet of the rivers, streams having similar discharges (Holston and Kanawha, Roanoke and Susquehanna) having less in common than others having different outlets (Kanawha, or Susquehanna and James).

"In view of the first proposition, and the question of the origin of species, the possibility of an original or subsequent mingling of the fresh waters suggests itself as more probable than that of distinct origin in the different basins."

Two questions in this connection are raised by Professor Cope. The first question is this: "Has any destruction of the river faunæ taken place since the first elevation of the Alleghanies, when the same species were thrown into waters flowing in opposite directions?" Of such destruction by submergence or otherwise, Professor Cope finds no evidence. The second question is, "Has any means of communication existed, at any time, but especially since the last submergence, by which the transfer of species might occur?" Some evidence of such transfer exists in the wide distribution of certain species, especially those which 
seek the highest streamlets in the mountains; but except to call attention to the cavernous character of the Subcarboniferous and Devonian limestones, Professor Cope has made little attempt to account for it.

Professor Cope finally concludes with this important generalization:-

"It would appear, from the previous considerations, that the distribution of fresh-water fishes is governed by laws similar to those controlling terrestrial vertebrates and other animals, in spite of the seemingly confined nature of their habitat."

Dr. Günther ${ }^{1}$ has well summarized some of the known facts in regard to the manner of dispersion of fishes:-

"The ways in which the dispersal of fresh-water fishes has been effected were various. They are probably all still in operation, but most work so slowly and imperceptibly as to escape direct observation; perhaps they will be more conspicuous after science and scientific inquiry shall have reached a somewhat greater age. From the great number of fresh-water forms which we see at this present day acclimatized in, gradually acclimatizing themselves in, or periodically or sporadically migrating into, the sea, we must conclude that under certain circumstances salt water may cease to be a barrier at some period of the existence of fresh-water species, and that many of them have passed. from one river through salt water into another. Secondly, the head-waters of some of the grandest rivers, the mouths of which are at opposite ends of the continents which they drain, are sometimes distant from each other a few miles only. The

1 Guide to the Study of Fishes, I880, p. 2 I I. 
intervening space may have been easily bridged over for the passage of fishes by a slight geological change affecting the level of the water-shed or even by temporary floods ; and a communication of this kind, if existing for a limited period only, would afford the ready means of an exchange of a number of species previously peculiar to one or the other of these river or lake systems. Some fishes provided with gill-openings so narrow that the water moistening the gills cannot readily evaporate, and endowed, besides, with an extraordinary degree of vitality, like many Siluroids (Clarias, Callichthys), Eels, etc., are enabled to wander for some distance over land, and may thus reach a water-course leading them thousands of miles from their original home. Finally, fishes or their ova may be accidentally carried by water-spouts, by aquatic birds or insects, to considerable distances."

A somewhat detailed statement of the known facts, arranged in the form of twenty-eight propositions, was given by me in $1878.1^{1}$ To these some further data were added in a paper by Professor Gilbert and myself on the fishes of Arkansas and Texas, ${ }^{2}$ published during the past year. These few memoirs, four or five in number, and dealing chiefly with other things, give about all that has been done in the way of generalization on this subject; and in none of these is the question of causes or methods in distribution dealt with in detail or to any important extent.

1 On the Distribution of the Fishes of the Alleghany Region, of South Carolina, Georgia, and Tennessee, with Descriptions of new or little-known Species. Bull. U. S. Nat. Mus., xii. 1878, pp. 9I95.

2 List of Fishes collected in Arkansas, Indian Territory, and Texas, in September, I884, with Notes and Descriptions. Proc. U. S. Nat. Mus., I886, pp. I-25. 


\section{We now recognize about six hundred species $^{1}$} of fishes as found in the fresh waters of North

1 The table below shows approximately the composition of the fresh-water fish-fauna of Europe, as compared with that of North America north of the Tropic of Cancer. (See a review of Seeley's "Fresh Water Fishes of Europe," The Dial, Chicago, June, '86, p. 35.)

FAMILIES.

EUROPE. N. AMERICA.

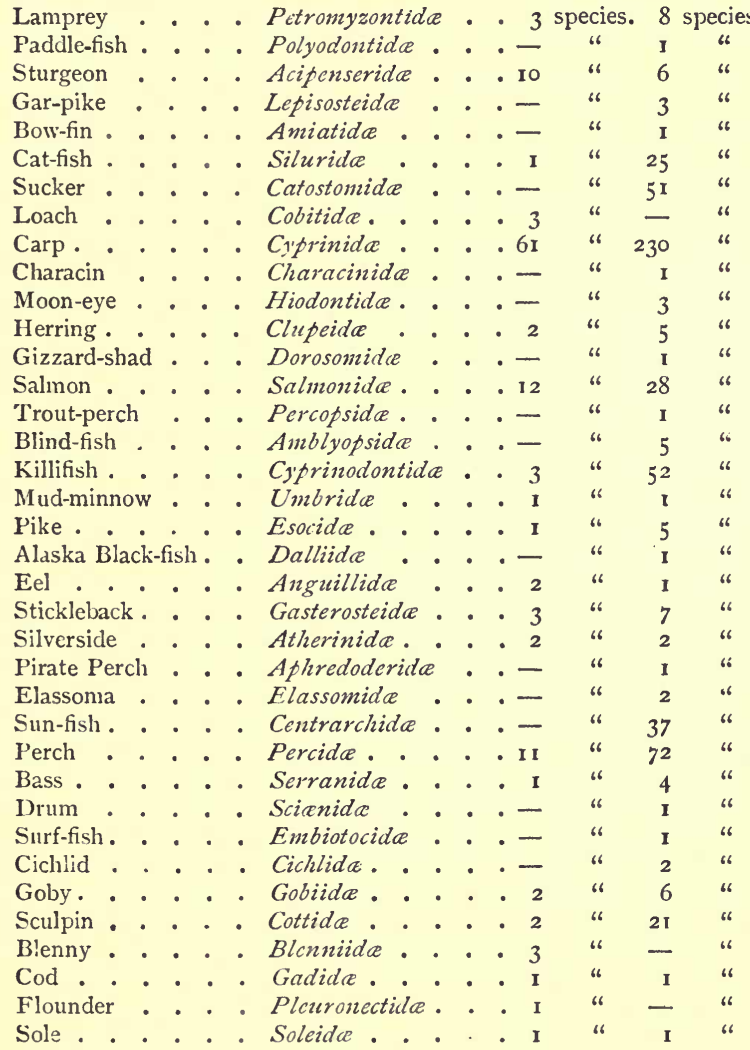

Total : Europe, 21 families; 126 species. North America, 34 families; 587 species.

According to Dr. Günther (Guide to the Study of Fishes, p. 243), the total number of species now known from the temperate 
America, north of the Tropic of Cancer, these representing thirty-four of the natural families. As to their habits, we can divide these species rather roughly into the four categories proposed by Professor Cope, or, as we may call them, -

(I) Lowland fishes; as the Bow-fin, ${ }^{1}$ Pirate Perch, ${ }^{2}$ large-mouthed Black Bass, ${ }^{3}$ Sun-fishes and some Cat-fishes.

(2) Channel-fishes; as the Channel Cat-fish, ${ }^{4}$ the Moon-eye, ${ }^{5}$ Gar-pike, ${ }^{6}$ Buffalo-fishes, ${ }^{7}$ and Drum. ${ }^{8}$

(3) Upland fishes; as many of the Darters, Shiners and Suckers, and the small-mouthed Black Bass. ${ }^{9}$

(4) Mountain-fishes; as the Brook Trout, and many of the Darters and Minnows.

To these we may add the more or less distinct classes of (5) Lake-fishes, inhabiting only waters which are deep, clear, and cold, as the various species of White-fish ${ }^{10}$ and the Great Laike Trout; ${ }^{11}$

regions of Asia and Europe is about 360. The fauna of India, south of the Himalayas, is much more extensive, numbering 625 species. This latter fauna bears little resemblance to that of North America, being wholly tropical in its character.

1 Amiatus calvus Linnæus.

2 Aphredoderus sayanus Gilliams.

3 Micropterus salmoidcs Lacépède.

4 Ictalurus punctatus Rafinesque.

5 Hiodon tergisus Le Sueur.

6 Lepisosteus osseus Linnæus.

7 Yctiobus bubalus, cyprinella, etc.

8 Aplodinotus grunniens Rafinesque.

9 Micropterus dolomieu Lacépède.

10 Coregonus clupeiformis, artedi, etc.

11 Salvelinus namaycush Walbaum. 
(6) Anadromous fishes, or those which run up from the sea to spawn in fresh waters, as the Salmon, ${ }^{1}$ Sturgeon, ${ }^{2}$ Shad, ${ }^{3}$ and Striped Bass; ${ }^{4}$ (7) Catadromous fishes, like the Eel, ${ }^{5}$ which pass down to spawn in the sea; and (8) brackish-water fishes, which thrive best in the debatable waters of the river-mouths, as most of the Sticklebacks and the Killifishes.

As regards the range of species, we have every possible gradation from those which seem to be confined to a single river, and are rare even in their restricted habitat, to those which are in a measure cosmopolitan, ${ }^{6}$ ranging everywhere in suitable waters.

Still, again, we have all degrees of constancy and inconstancy in what we regard as the characters of a species. Those found only in a single riverbasin are usually uniform enough; but the species having a wide range usually vary much in different localities. Such variations have at different times been taken to be the indications of as many different species. Continued explorations bring to light, from year to year, new species; but the number of new forms now discovered each year is usually less than the number of recognized species which are yearly proved to be intenable. Three complete lists of the fresh-water fishes of the United States

1 Salmo salar Linnæus.

${ }^{3}$ Clupea sapidissima Wilson.

5 Arguilla anguilla Linnæus.

6 Thus the Chub-sucker (Erimyzon sucetti) in some of its varieties ranges everywhere from Maine to Dakota, Florida, and Texas; while a number of other species are scarcely less widely distributed. 
have been published by the present writer. That of Jordan and Copeland, ${ }^{1}$ published in 1876 , enumerates 670 species. That of Jordan ${ }^{2}$ in 1878 contains 665 species, and that of Jordan ${ }^{3}$ in 1885 , 587 species, although upwards of 75 new species were detected in the nine years which elapsed between the first and the last list. Additional specimens from intervening localities are often found to form connecting links among the nominal species, and thus several supposed species become in time merged in one. Thus the Common Channel Cat-fish ${ }^{4}$ of our rivers has been described as a new species not less than twenty-five times, on account of differences real or imaginary, but comparatively trifling in value.

Where species can readily migrate, their uniformity is preserved; but whenever a form becomes localized its representatives assume some charac-. ters not shared by the species as a whole. When we can trace, as we often can, the disappearance by degrees of these characters, such forms no longer represent to us distinct species. In cases where the connecting forms are extinct, or at least not represented in collections, each form which is

1 Check List of the Fishes of the Fresh Waters of North America, by David S. Jordan and Herbert E. Copeland. Bulletin of the Buffalo Society of Natural History, r876, pp. 133-r64.

2 A Catalogue of the Fishes of the Fresh Waters of North America. Bulletin of the United States Geological Survey, 1878 , pp. 407-442.

3 A Catalogue of the Fishes known to inhabit the Waters of North America North of the Tropic of Cancer. Annual Report of the Commissioners of Fish and Fisheries for $188_{4}$ and $1885=$

4 Ictaluris punctatus Rafinesque. 
apparently different must be regarded as a distinct species.

The variations in any type become, in general, more marked as we approach the tropics. The genera are represented, on the whole, by more species there, and it would appear that the processes of specific change go on more rapidly under the easier conditions of life in the Torrid Zone.

We recognize now in North America twenty-five distinct species of fresh-water Cat-fishes, ${ }^{1}$ although nearly a hundred (93) nominal species of these fishes have been from time to time described. But these twenty-five species are among themselves very closely related, and all of them are subject to a variety of minor changes. It requires no strong effort of the imagination to see in them all the modified descendants of some one species of Cat-fish, not unlike our Common "Bull-head," - an immigrant probably from Asia, and which has now adjusted itself to its surroundings in each of our myriad of Cat-fish breeding streams.

The word "species," then, is simply a term of convenience, including such members of a group similar to each other as are tangibly different from others, and are not known to be connected with these by intermediate forms. Such connecting links we may suppose to have existed in all cases. We are only sure that they do not now exist in our collections, so far as these have been carefully studied.

When two or more species of any genus now inhabit the same waters, they are usually species 
whose differentiation is of long standing, - species, therefore, which can be readily distinguished from one another. When, on the other hand, we have "representative species," - closely related forms, neither of which is found within the geographical range of the other, - we can with some confidence look for intermediate forms where the territory occupied by the one bounds that inhabited by the other. In very many such cases the intermediate forms have been found; and such forms are considered as sub-species of one species, the one being regarded as the parent stock, the other as an offshoot due to the influences of different environment. Then, besides these "species" and "sub-species," groups more or less readily recognizable, there are varieties and variations of every grade, often too ill-defined to receive any sort of name, but still not without significance to the student of the origin of species. Comparing a dozen fresh specimens of almost any kind of fish from any body of water with an equal number from somewhere else, one will rarely fail to find some sort of differences, - in size, in form, in color. These differences are obviously the reflex of differences in the environment, and the collector of fishes seldom fails to recognize them as such; often it is not difficult to refer the effect to the conditions. Thus, fishes from grassy bottoms are darker than those taken from over sand, and those from a bottom of muck are darker still, the shade of color being, in some way not well understood, dependent on the color of the surroundings. Fishes in large bodies of water reach 
a larger size than the same species in smaller streams or ponds. Fishes from foul or sedimentladen waters are paler in color and slenderer in form than those from waters which are clear and pure. Again, it is often true that specimens from northern waters are less slender in body than those from farther south; and so on. Other things being equal, the more remote the localities from each other, the greater are these differences.

In our fresh-water fishes each species on an average has been described as new from three to four times, on account of minor variations, real or supposed. In Europe, where the fishes have been studied longer and by more different men, upwards of six or eight nominal species have been described for each one that is now considered distinct.

It is evident, from these and other facts, that the idea of a separate creation for each species of fishes in each river basin, as entertained by Agassiz, is wholly incompatible with our present knowledge of the specific distinctions or of the geographical distribution of fishes. This is an unbroken gradation in the variations from the least to the greatest, - from the peculiarities of the individual, through local varieties, geographical sub-species, species, sub-genera, genera, families, super-families, and so on, until all fish-like vertebrates are included in a single bond of union.

It is, however, evident that not all American types of fishes had their origin in America, or even first assumed in America their present forms. Some of these are perhaps immigrants from northern Asia, where they still have their nearest 
relatives. Still others are evidently modified importations from the sea; and of these some are very recent immigrants, landlocked species which have changed very little from the parent stock.

The character and possible origin of each of the thirty-four families of North American fresh-water fishes may be briefly summarized as follows:-

The Lampreys are evidently of marine origin, as the marine species are still anadromous. The fresh-water species, compared with the marine ones, are smaller in size and weaker in organization, and represent larval conditions or arrests of development of the latter form.

The Paddle-fish is allied to extinct ganoid types. The group is now represented by one species in America and another in central Asia.

The Sturgcons, like the Lampreys, are anadromous. But two of the American species are now confined to the fresh waters, and one of these belongs to a peculiar genus (Scaphirhynchus), which (like Polyodon) has representatives also in central Asia. As to whether the parent stock in either case is American or Asiatic, I know of no positive evidence.

The Gar-piks and the Bow-fins are strictly American types allied to extinct ganoid forms, and doubtless developed from such in the waters they now inhabit.

The Cat-fishes of America are all probably descendants of a common stock, not allied to South American forms, but probably finding its nearest relatives in India. A single species of this type now exists in China (Ameiums cantonensis); but 
this is perhaps a returned emigrant from America, rather than a direct offshoot of the parent stock.

The Suckers are modified Cyprinida, probably developed originally in America, although one species has spread from Alaska to Siberia, and another very peculiar form exists in China. Whatever its origin, this group is now one of the most characteristic of our fauna.

The Cyprinide of western America are more or less closely related to Old World types, and some of them, like the Old World species, reach a great size. East of the Rocky Mountains are found a multitude of species, mostly of small size and weak organization, which seem to be degenerate or reduced representatives of Old World types, and which have for the most part no immediate relatives among the latter. The majority of these species are now placed in a single genus, Notropis, which is found only in America, and is one of the most characteristic of our fish-fauna.

The Characins belong to the tropics, especially to South America. The single species which crosses the Rio Grande is doubtless an immigrant from Mexico. The same remarks apply also to the Cichlids, - a group especially characteristic of tropical America, one species of which reaches southern Texas.

The Moon-eyes are characteristically American type, with no near relatives elsewhere in the world. Their ancestors were probably immigrants from the sea.

The Herring permanently resident in our fresh waters are simply landlocked representatives of 
species still found in the sea along our coasts. Other species are anadromous, ascending the rivers in the spring.

The Gizsard-shad is indifferently marine, anadromous, or landlocked, and is still extending its range in sluggish waters through the agency of canals.

The various forms of Salmonida abound in the streams and lakes of all northern regions. The larger species are marine and anadromous, the smaller confined to lakes and brooks; but all seek streams or at least shallower waters for the purpose of spawning. The whole group had probably a marine origin; the more strictly fresh-water species being, as is usually the case, smaller in size, weaker in organization, and with feebler dentition. It is often assumed that this group has had its origin in the Atlantic; but whether in America or in Europe, we have no means of inferring.

The Trout-perch show a curious combination of characters of spiny and soft-rayed fishes. The single species is probably, as suggested by Agassiz, a relic of an ancient fauna.

The Blind-fishes are also very unique in their organization. Two of the known species have well-developed eyes, and live in lowland streams and springs. Such are doubtless ancestors of the eyeless forms of the cave streams, but the immediate progenitors and relatives of these seem to be extinct. They were probably fresh-water rather than marine forms, and of the same general stock as the ancestors of the Killifishes, Mud-minnows, and Pike. 
The Killifishes have their greatest abundance in tropical America, which is perhaps the place of their origin. They are especially fishes of the brackish waters, rarely going far out to sea. Some of them ascend streams; and these frequent spring waters, and waters which are clear and cold.

The two species of Mud-minnow are now very widely separated as to habitat, although very similar to each other in structure. The one belongs properly to our Great Lake Fauna, the other to the streams of Austria. The two are probably remains of a past fauna, in which the group was more fully represented. Our Mud-minnow ${ }^{1}$ is one of the most tenacious of life of all our fishes, and will often live for weeks in damp muck after the waters of a pond have evaporated.

Of the five known species of Pike, one is cosmopolitan, being spread over northern Asia and Europe as well as America, while the other species are somewhat restricted in their range. The Common Pike ${ }^{2}$ is probably the parent stock of all; but whether originally American or not, we cannot say. The affinities of the Mud-minnow with the Pike are not remote, and doubtless forms between the two have existed.

The Black-fis/ ${ }^{3}$ of Alaska is another relative of the Mud-minnow and Pike. The single known species is found in Alaska and eastern Siberia. It too is probably an isolated relic of a disappearing group.

1 Umbra limi Kirtland.

2 Esox lucius Linnæus.

\& Dallia pectoralis Bean. 
The Common Eel ${ }^{1}$ is more or less regularly catadromous. It is doubtless of marine origin; and the same species is widely diffused in America and Europe, though curiously wanting on our Pacific coasts, as well as in South America.

The Sticklebacks and the Silversides are seashore fishes, the former of cold, the latter of warm regions. Some species of both are now permanent residents in fresh water. The Sticklebacks especially show all degrees of transition, the strictly fluviatile forms being as usual smaller in size and weaker in armature than the marine ones.

The Pirate Perches and the Elassoma are two very small families, related to each other, and distantly related perhaps to the Sun-fishes. They are probably remains of some older fauna, and are possibly allied to the Berycoids; but this relation, if real, is not very close.

The Sun-fishes are peculiarly North American, nothing similar being found in any other region. Their ancestry is probably to be sought among the marine Serranide, the large-mouthed Black Bass ${ }^{2}$ being probably the member of the former group nearest the parent stock.

The fresh-water (striped) Bass ${ }^{3}$ are evidently allied to the anadromous members of the same group.

The Perch family is perhaps originally an offshoot from the Sea Bass. It has, however, received a peculiar development in American waters.

1 Anguilla anguilla Linnæus.

2 Micropterus salmoides Lacépède.

3 Morone chry'sops, mississifpiensis, etc. 
The large group or genus of Darters ${ }^{1}$ is composed of small, brilliantly colored Perches, whose structure is especially adapted for life on the rocky bottoms of small clear streams. The relations of these species to the typical Perches have been admirably discussed by Professor S. A. Forbes, from whose paper $^{2}$ I make the following quotations :-

"We must inquire, therefore, into the causes which have operated on a group of Percoids to limit their range to such apparently unfavorable conditions, to diminish their size, to develop unduly the paired fins and reduce the air-bladder, to remove the scales of several species more or less completely, . . . and to restrict their food chiefly to a few forms [of insect-larvæ and crustacea].

"No species can long maintain itself anywhere which cannot in some way find a sufficient supply of food and also protect itself against its enemies. In its contests with its enemies it may acquire defensive structures or powers of escape sufficient for its protection, or it may become adapted to some place of refuge where other fishes will not follow. What better refuge could a harassed fish desire than the hiding-places among stones in the shallows of a stream where the water dashes ceaselessly by with a swiftness few fish can stem? And if at the same time the refugee develop a swimming power which enables it to dart like a flash against the strongest current, its safety would seem to be insured. But what food could it find in such a place? Let us turn over the stones in such a stream, sweeping the roiled water at the same time with a small cloth net, and we shall find larva

\section{Etheostoma.}

2 A Catalogue of the Native Fishes of Illinois. Report of the Illinois Fish Commissioners, I884, p. 95. 
of Chironomus and small Ephemerids, and other such prey and little else, - food too minute and difficult of access to support a large fish, but answering very well if our immigrant can keep down his size. . . The limited supply of food early arrests the growth of the young; while every fish which passes the allowable maximum is forced for food to brave the dangers of the deeper waters, where the chances are that it falls a prey. On the other hand, the smaller the size of those which escape this alternative, the less likely will they be to attract the appetite of the small gar or other guerilla, which may occasionally raid their retreat, and the more easily will they slip about under stones in search of their microscopic game.

"Like other fishes, the darters must have their periods of repose, all the more urgent because of the constant struggle with the swift current which their habitat inposes. Shut out from the deep, still pools and slow eddies where the larger species lurk, they are forced to spend their leisure on or beneath the bottom of the stream, resting on their extended ventrals and anal, or wholly buried in the sand. ...

"Doubtless the search for food has much to do with this selection in a habitat. I have found that the young of nearly all species of our fresh-water fishes are competitors for food, feeding almost entirely on Entomostraca. and the larvæ of minute Diptera. As a tree sends out its roots in all directions in search of nourishment, so each of the larger divisions of animals extends its various groups into every place where available food occurs, each group becoming adapted to the special features of its situation. Given this supply of certain kinds of food, nearly inaccessible to the ordinary fish, it is to be expected that some fishes would become especially fitted to its utilization. Thus the Etheostomatina [Darters] as a group are to be 
explained, in a word, by the hypothesis of the progressive adaptation of the young of certain Percide to a peculiar place of refuge and a peculiar food-supply.

"Perhaps we may, without violence, call these the mountaineers among fishes. Forced from the populous and fertile valleys of the river beds and lake bottoms, they have taken refuge from their enemies in the rocky highlands, where the free waters play in ceaseless torrents, and there they have wrested from stubborn Nature a meagre living. Although diminished in size by their continual struggle with the elements, they have developed an activity and hardihood, a vigor of life, and glow of high color almost unknown among the easier livers of the lower lands."

It is noteworthy that among the European genera of Percide, one of them, Aspro, has assumed a similar habitat, and adapted - apparently as a result of its surroundings - characters similar to those of Etheostoma. It is not likely that Aspro is an ancestor of Etheostoma, still less likely that $A s$ pro is descended from the latter genus. The similar development of the two seems rather a case of analogous variation, the influence of similar conditions in different places on similar organisms.

It is remarkable, also, that in mountain regions in which no Percidce are found, fishes very similar to the Darters in appearance and habits, though totally different in structure, have by analogous agencies been developed. Loaches, Cat-fishes, Gobies, Characins, Sculpins, in different parts of the world inhabit swift mountain streams, and in a similar way become dwarfed and concentrated, taking the place in their respective habitats which 
the Darters occupy in the waters of the Mississippi Valley.

By the same process of "analogous variation" the Cichlide of South America parallel the Sunfishes of the United States, although in structure and in origin the two groups are diverse.

The single species each of Drum, ${ }^{1}$ Surf-fish, ${ }^{2}$ and $\mathrm{Cod}^{3}$ found in our fresh waters are evidently immigrants from the sea, although not of recent origin. The several species of Sculpin have apparently come from two separate marine stocks, - the one (Cottus) comparatively ancient and probably originating in the Pacific, the other (Triglopsis) more modern and descended from an Atlantic species (Acanthocottus quadricomis, L.). The former type is now diffused in all cold waters of North America, Europe, and northern Asia. The latter belongs only to the depths of the Great Lakes.

The Flounders and Soles when found in fresh waters are merely temporary sojourners from the sea.

We can say, in general, that in all waters not absolutely uninhabitable there are fishes. The processes of natural selection have given to each kind of river or lake species of fishes adapted to the conditions of life which obtain there. There is no condition of water, of bottom, of depth, of speed of current, but finds some species with characters adjusted to it. These adjustments are, for the most part, of long standing; and the fauna

1 Aplodinotus grunniens Rafinesque.

2 Hysterocarpus traski Gibbons.

3 Lota lota Linnæus. 
of any single stream has, as a rule, been produced by immigration from other regions or from other streams. Each species has an ascertainable range of distribution, and within this range we may be reasonably certain to find it in any suitable waters.

But every species has beyond question some sort of limit to its distribution, some sort of barrier which it has never passed in all the years of its existence. That this is true becomes evident when we compare the fish-faunæ of widely separated rivers. Thus the Sacramento, Connecticut, Rio Grande, and St. John's Rivers have not a single species in common; and with one or two exceptions, not a species is common to any two of them. None of these ${ }^{1}$ has any species peculiar to itself, and each shares a large part of its fish-fauna with the water-basin next to it. It is probably true that the faunæ of no two distinct hydrographic basins are wholly identical, while on the other hand there are very few species confined to a single one. The supposed cases of this character, some twenty in number, occur chiefly in the streams of the South Atlantic States and of Arizona. All of these need, however, the confirmation of further exploration. It is certain that in no case has an entire river-fauna ${ }^{2}$ originated independently from the divergence into separate species of the descendants of a single type.

The existence of boundaries to the range of

1 Except possibly the Sacramento.

2 Unless the fauna of certain cave-streams in the United States and Cuba be regarded as forming an exception. 
species implies, therefore, the existence of barriers to their diffusion. We may now consider these barriers, and, in the same connection, the degree to which they may be overcome.

Least important of these are the barriers which may exist within the limits of any single basin, and which tend to prevent a free diffusion through its waters of species inhabiting any portion of it. In streams flowing southward, or across different parallels of latitude, the difference in climate becomes a matter of importance. The distribution of species is governed very largely by the temperature of the water. Each species has its range in this respect, - the free-swimming fishes, notably the Trout, being most affected by it; the mudloving or bottom fishes, like the Cat-fishes, least. The latter can reach the cool bottoms in hot weather, or the warm bottoms in cold weather, thus keeping their own temperature more even than that of the surface of the water. Although water-communication is perfectly free for most of the length of the Mississippi, there is a material difference between the faunæ of the stream in Minnesota and in Louisiana. This difference is caused chiefly by the difference in temperature occupying the difference in latitude. That a similar difference in longitude, with free water communication, has no appreciable importance, is shown by the almost absolute identity of the fish-faunæ of Lake Winnebago and Lake Champlain. While many large fishes range freely up and down the Mississippi, a majority of the species do not do so, and the fauna of the upper Mississippi has more in 
common with that of the tributaries of Lake Michigan than it has with that of the Red River or the Arkansas. The influence of climate is again shown in the paucity of the fauna of the cold waters of Lake Superior, as compared with that of Lake Michigan. The majority of our species cannot endure the cold. In general, therefore, cold or Northern waters contain fewer species than Southern waters do, though the number of individuals of any one kind may be greater. This is shown in all waters, fresh or salt. The fisheries of the Northern seas are more extensive than those of the Tropics. There are more fishes there, but they are far less varied in kind. The writer once caught seventy-five species of fishes in a single haul of the seine at Key West, while on Cape Cod he obtained with the same net but forty-five species in the course of a week's work. Thus it comes that the angler, contented with many fishes of few kinds, goes to Northern streams to fish, while the naturalist goes to the South.

But in most streams the difference in latitude is insignificant, and the chief differences in temperature come from differences in elevation, or from the distance of the waters from the colder source. Often the lowland waters are so different in character as to produce a marked change in the quality of their fauna. These lowland waters may form a barrier to the free movements of upland fishes; but that this barrier is not impassable is shown by the identity of the fishes in the streams ${ }^{1}$ of the

' For example, Elk River, Duck River, etc. 
uplands of middle Tennessee with those of the Holston and French Broad. Again, streams of the Ozark Mountains, similar in character to the rivers of East Tennessee, have an essentially similar fishfauna, although between the Ozarks and the Cumberland range lies an area of lowland bayous, into which such fishes are never known to penetrate. We can, however, imagine that these upland fishes may be sometimes swept down from one side or the other into the Mississippi, from which they might ascend on the other side. But such transfers certainly do not often happen. This is apparent from the fact that the two faun ${ }^{1}$ are not quite identical, and in some cases the same species are represented by perceptibly different varieties on one side and the other. The time of the commingling of these faunæ is perhaps now past, and it may have occurred only when the climate of the intervening regions was colder than at present.

The effect of waterfalls and cascades as a barrier to the diffusion of most species is self-evident; but the importance of such obstacles is less, in the course of time, than might be expected. In one way or another very many species have passed these barriers. The falls of the Cumberland limit

1 There are three species of Darters (Etheostoma copelandi Jordan; Etheostoma evides Jordan and Copeland; Etheostoma scierum Swain) which are now known only from the Ozark region or beyond and from the uplands of Indiana, not yet having been found at any point between Indiana and Missouri. These constitute perhaps isolated colonies, now separated from the parent stock in Arkansas by the prairie districts of Illinois, a region at present uninhabitable for these fishes. IBut the non-occurrence of these species over the intervening areas necds confirmation, as do most similar cases of anomalous distribution. 
the range of most of the larger fishes of the river, but the streams above it have their quota of Darters and Minnows. It is evident that the past history of the stream must enter as a factor into this discussion, but this past history it is not always possible to trace. Dams or artificial waterfalls now check the free movement of many species, especially those of migratory habits; while, conversely, numerous other species have extended their range through the agency of canals. ${ }^{1}$

Every year fishes are swept down the rivers by the winter's floods; and in the spring, as the spawning season approaches, almost every species is found working its way up the stream. In some cases, notably the Quinnat Salmon ${ }^{2}$ and the Blueback Salmon, ${ }^{3}$ the length of these migrations is surprisingly great. To some species rapids and shallows have proved a sufficient barrier, and other kinds have been kept back by unfavorable conditions of various sorts. Streams whose waters are always charged with silt or sediment, as the Missouri, Arkansas, or Brazos, do not invite fishes; and even the occasional floods of red mud such as disfigure otherwise clear streams, like the Red River or the Colorado (of Texas), are unfavorable. Extremely unfavorable also is the condition which obtains in many rivers of the Southwest; as for example, the Red River, the Sabine, and the Trinity, which are full from bank to bank in winter and

1 Thus, Dorosoma cepedianum Le Sueur, and Clupea chrysochloris Rafinesque, have found their way into Lake Michigan through canals.

2 Oncorhynchus tschazeytscha Walbaum.

3 Oncorhynitus nerka Walbaum. 
spring, and which dwindle to mere rivulets in the autumn droughts.

In general, those streams which have conditions most favorable to fish-life will be found to contain the greatest number of species. Such streams invite immigration; and in them the struggle for existence is individual against individual, species against species, and not a mere struggle with hard conditions of life. Some of the conditions most favorable to the existence in any stream of a large number of species of fishes are the following, the most important of which is the one mentioned first: connection with a large hydrographic basin; a warm climate; clear water; a moderate current; a bottom of gravel (preferably covered by a growth of weeds); little fluctuation during the year in the volume of the stream or in the character of the water.

Limestone streams usually yield more species than streams flowing over sandstone, and either more than the streams of regions having metamorphic rocks. Sandy bottoms usually are not favorable to fishes. In general, glacial drift makes a suitable river bottom, but the higher temperature usual in regions beyond the limits of the drift gives to certain Southern streams conditions still more favorable. These conditions are all well realized in the Washita River in Arkansas, and in various tributaries of the Tennessee, Cumberland, and Ohio; and in these, among American streams, the greatest number of species has been recorded.

The isolation and the low temperature of the rivers of New England have given to them a very 
scanty fish-fauna as compared with the rivers of the South and West. This fact has been noticed by Professor Agassiz, who has called New England a "zoölogical island." 1

In spite of the fact that barriers of every sort are sometimes crossed by fresh-water fishes, we must still regard the matter of freedom of water communication as the essential one in determining the range of most species. The larger the river basin, the greater the variety of conditions likely to be offered in it, and the greater the number of its species. In case of the divergence of new forms by the processes called "natural selection," the greater the number of such forms which may have spread through its waters; the more extended any river basin, the greater are the chances that any given species may sometime find its way into it; hence the greater the number of species that actually occur in it, and, freedom of movement being assumed, the greater the number of species to be found in any one of its affluents.

Of the six hundred species of fishes found in the rivers of the United States, about two hundred have been recorded from the basin of the Mississippi. From fifty to one hundred of these

1 "In this isolated region of North America, in this zoölogical island of New England, as we may call it, we find neither Lepidosteus, nor Amia, nor Polyodon, nor Amblodon (Aplodinotus), nor Grystes (Micropterus), nor Centrarchus, nor Pomoxis, nor Ambloplites, nor Calliurus (Chanobryitus), nor Carpiodes, nor Hyodon, nor indeed any of the characteristic forms of North American fishes so common everywhere else, with the exception of two Pomotis (Lepomis), one Boleosoma, and a few Catostomus." AgAssiz, Amer. Journ. Sci. Arts, 1854 . 
species can be found in any one of the tributary streams of the size, say, of the Housatonic River or the Charles. In the Connecticut River there are but about eighteen species permanently resident; and the number found in the streams of Texas is not much larger, the best-known of these, the Rio Colorado, having yielded but twenty-four species.

The waters of the Great Basin have not yet been fully explored. The number of species now known from this region is about seventy-five. This number includes the fauna of the upper Rio Grande, the Snake River, and the Colorado, as well as the fishes of the tributaries of the Great Salt Lake. This list is composed almost entirely of a few genera of Suckers, ${ }^{1}$ Minnows, ${ }^{2}$ and Trout. $^{3}$ None of the Cat-fishes, Perch, Darters, or Sunfishes, Moon-eyes, Pike, Killifishes, and none of the ordinary Eastern types of Minnows ${ }^{4}$ have passed the barrier of the Rocky Mountains.

West of the Sierra Nevada, the fauna is still more scanty, but fifty species being enumerated. This fauna, except for certain immigrants ${ }^{5}$ from the sea, is of the same general character as that of the Great Basin, though most of the species are different. This latter fact would indicate a considerable change, or "evolution," since the contents of the two faunæ were last mingled. There

1 Catostomus, Pantosteus, Chasmistes.

2 Squalius, Gila, Ptychocheilus, etc.

3 Salmo mykiss and its varieties.

4 Genera Notropis, Chrosomus, etc.

5 As the fresh-water Surf-fish (Hysterocarpus traski) and the species of Salmon. 
is a considerable difference between the fauna of the Columbia and that of the Sacramento. The species which these two basins have in common are chiefly those which at times pass out into the sea. The rivers of Alaska contain but few species, barely a dozen in all, most of these being found also in Siberia and Kamtschatka. In the scantiness of its faunal list, the Yukon agrees with the Mackenzie River, and with Arctic rivers generally.

There can be no doubt that the general tendency is for each species to extend its range more and more widely until all localities suitable for its growth are included. The various agencies of dispersal which have existed in the past are still in operation. There is apparently no limit to their action. It is probable that new "colonies" of one species or another may be planted each year in waters not heretofore inhabited by such species. But such colonies become permanent only where the conditions are so favorable that the species can hold its own in the struggle for food and subsistence. That various modifications in the habitat of certain species have been caused by human agencies is of course too well known to need discussion here.

We may next consider the question of watersheds, or barriers which separate one river basin from another.

Of such barriers in the United States, the most important and most effective is unquestionably that of the main chain of the Rocky Mountains. This is due in part to its great height, still more to its great breadth, and most of all, perhaps, to 
the fact that it is nowhere broken by the passage of a river. But two species - the Red-throated, or Rocky Mountain Trout, ${ }^{1}$ and the Rocky Mountain White-fish ${ }^{2}$ - are found on both sides of it, at least within the limits of the United States; while many genera, and even several families, find in it either an eastern or a western limit to their range. In a few instances representative species, probably modifications or separated branches of the same stock, occur on opposite sides of the range, but there are not many cases of correspondence even thus close. The two faunæ are practically distinct. Even the widely distributed Red-spotted, or "Dolly Varden " Trout, ${ }^{3}$ of the Columbia River and its affluents, does not cross to the east side of the mountains; nor does the Great Lake Trout ${ }^{4}$ nor the Montana Grayling ${ }^{5}$ ever make its way to the West.

It is easy to account for this separation of the faunæ; but how shall we explain the almost universal diffusion of the White-fish and the Trout in suitable waters on both sides of the dividing ridge? We may notice that these two are the species which ascend highest in the mountains, the White-fish inhabiting the mountain pools and lakes, the Trout ascending all brooks and rapids in search of their fountain-heads. In many cases the ultimate dividing ridge is not very broad, and we may imagine

1 Salmo mykiss Walbaum (= purpuratus Pallas).

2 Coregonus williamsoni Girard.

8 Salvelinus malma Walbaum.

4 Salvelinus namaycush Walbaum.

5 Thymallus signifer ontariensis Valenciennes. 
that at some time spawn or even young fishes may have been carried across by birds or other animals, or by man, - or more likely by the dash of some summer whirlwind. Once carried across in favorable circumstances, the species might survive and spread.

I saw last summer an example of how such transfer of species may be accomplished, which shows that we need not be left to draw on the imagination to invent possible means of transit.

There are few water-sheds in the world better defined than the mountain range which forms the "backbone" of Norway. I lately climbed a peak in this range, the Suletind. From its summit I could look down into the valleys of the Lära and the Bägna, flowing in opposite directions to opposite sides of the peninsula. To the north of the Suletind is a large double lake called the Sletningenvand. The maps show this lake to be one of the chief sources of the westward-flowing river Lära. This lake is in August swollen by the melting of the snows, and at the time of my visit it was visibly the source of both these rivers. From its southeastern side flowed a large brook into the valley of the Bägna, and from its southwestern corner, equally distinctly, came the waters which fed the Lära. This lake, like similar mountain ponds in all northern countries, abounds in trout; and these trout certainly have for part of the year an uninterrupted line of water communication from the Sognefjord on the west of Norway to the Christianiafjord on the southeast, - from the North Sea to the Baltic. Part of the year the lake 
has probably but a single outlet through the Lära. A higher temperature would entirely cut off the flow into the Bägna, and a still higher one might dry up the lake altogether. This Sletningenvand, ${ }^{1}$ with its two outlets on the summit of a sharp water-shed, may serve to show us how other lakes, permanent or temporary, may elsewhere have acted as agencies for the transfer of fishes. We can also see how it might be that certain mountain fishes should be so transferred while the fishes of the upland waters may be left behind. In some such way as this we may imagine the Trout and the White-fish to have attained their present wide range in the Rocky Mountain region; and in similar manner perhaps the Eastern Brook Trout ${ }^{2}$ and some other mountain species ${ }^{3}$ may have been carried across the Alleghanies.

1 Since the above was written I have been informed by Professor John M. Coulter, who was one of the first explorers of the Yellowstone Park, that such a condition still exists on the Rocky Mountain Divide. In the Yellowstone Park is a marshy tract, traversable by fishes in the rainy season, and known as the "TwoOcean Water." In this tract rise tributaries both of the Snake River and of the Yellowstone. Similar conditions apparently exist on other parts of the Divide, both in Montana and in Wyoming.

Professor John C. Branner calls my attention to a marshy upland which separates the valley of the La Plata from that of the Amazon, and which permits the free movement of fishes from the Paraguay River to the Tapajos. It is well known that through the Cassiquiare River the Rio Negro, another branch of the Amazon, is joined to the Orinoco River. It is thus evident that almost all the waters of eastern South America form a single basin, so far as the fishes are concerned.

2 Salvelinus fontinalis Mitchill.

3 Notropis rubricroceus Cope; Rhinichthys atronasus Mitchill; etc. 
The Sierra Nevada constitutes also a very important barrier to the diffusion of species. This is, however, broken by the passage of the Columbia River, and many species thus find their way across it. That the waters to the west of it are not unfavorable for the growth of eastern fishes is shown by the fact of the rapid spread of the Common Eastern Cat-fish, ${ }^{1}$ or Horned Pout, when transported from the Schuylkill to the Sacramento. This fish is now one of the important food-fishes of the San Francisco markets. It has become, in fact, an especial favorite with the Chinaman, himself also an immigrant, and presenting certain analogies with the fish in question, as well in temperament as in habits.

The mountain mass of Mount Shasta is, as already stated, a considerable barrier to the range of fishes, though a number of species find their way around it through the sea. The lower and irregular ridges of the Coast Range are of small importance in this regard, as the streams of their east slope reach the sea on the west through San Francisco Bay. Yet the San Joaquin contains a few species, not yet recorded from the smaller rivers of southwestern California.

The main chain of the Alleghanies forms a barrier of importance separating the rich fish-fauna of the Tennessee and Ohio basins from the scantier faunæ of the Atlantic streams. Yet this barrier is crossed by many more species than is the case with either the Rocky Mountains or the Sierra Nevada. It is lower, narrower, and much more 
broken, - as in New York, in Pennsylvania, and in Georgia there are several streams which pass through it or around it. The much greater age of the Alleghany chain, as compared with the Rocky Mountains, seems not to be an element of any importance in this connection. Of the fish which cross this chain, the most prominent is the Brook Trout, ${ }^{1}$ which is found in all suitable waters from Hudson's Bay to the head of the Chattahoochee. A few other species are locally found in the headwaters of certain streams on opposite sides of the range. An example of this is the little red "Fallfish," 2 found only in the mountain tributaries of the Savannah and the Tennessee. We may suppose the same agencies to have assisted these species that we have imagined in the case of the Rocky Mountain Trout, and such agencies were doubtless more operative in the times immediately following the glacial epoch than they are now. Professor Cope calls attention also to the numerous caverns existing in these mountains, as a sufficient medium for the transfer of many species. I doubt whether the main chains of the Blue Ridge or the Great Smoky can be crossed in that way, though such channels are not rare in the subcarboniferous limestones of the Cumberland range.

The passage of species from stream to stream along the Atlantic slope deserves a moment's notice. It is, under present conditions, impossible for any mountain or upland fish, as the Trout or the Miller's Thumb, ${ }^{3}$ to cross from the Potomac

1 Salvelinus fontinalis.

2 Notrofis mubricroceus Cope.

3 Cothus richardsoni Agassiz. 
River to the James, or from the Neuse to the Santee, by descending to the lower courses of the rivers, and thence passing along either through the swamps or by way of the sea. The lower courses of these streams, warm and muddy, are uninhabitable by such fishes. Such transfers are, however, possible farther north. From the rivers of Canada and from many rivers of New England the Trout does descend to the sea and into the sea, and farther north the White-fish does this also. Thus these fishes readily pass from one river basin to another. As this is the case now everywhere in the North, it may have been the case farther south in the time of the glacial cold. We may, I think, imagine a condition of things in which the snow-fields of the Alleghany chain might have played some part in aiding the diffusion of cold-loving fishes. A permanent snow-field on the Blue Ridge in western North Carolina might render almost any stream in the Carolinas suitable for trout, from its source to its moutl. An increased volume of colder water might carry the trout of the head-streams of the Catawba and the Savannah as far down as the sea. We can even imagine that the trout reached these streams in the first place through such agencies, though of this there is no positive evidence. For the presence of trout in the upper Chattahoochee, we must account in some other way.

It is noteworthy that the upland fishes are nearly the same in all these streams, until we reach the southern limit of possible glacial influence. South of western North Carolina, the 
faunæ of the different river basins appear to be more distinct from one another. Certain rippleloving types ${ }^{1}$ are represented by closely related but unquestionably different species in each river basin, and it would appear that a thorough mingling of the upland species in these rivers has never taken place.

With the lowland species of the Southern rivers it is different. Few of these are confined within narrow limits. The streams of the whole South Atlantic and Gulf Coast flow into shallow bays, mostly bounded by sand-spits or sand-bars which the rivers themselves have brought down. In these bays the waters are often neither fresh nor salt; or rather, they are alternately fresh and salt, the former condition being that of the winter and spring. Many species descend into these

1 The best examples of this are the following: in the Santee basin are found Notropis pyrrhomelas, Notropis niveus, and Notropis chloristius; in the Altamaha, Notropis xamurus and Notropis callisemus; in the Chattahoochee, Notropis hypselopterus and Notropis eurystomus; in the Alabama, Notropis cornuleus, Notropis trichroistius, and Notropis callistius. In the Alabama, Escambia, Pearl, and numerous other rivers, is found Notropis cercostigma. This species descends to the sea in the cool streams of the pine-woods. Its range is wider than that of the others, and in the rivers of Texas it reappears in the form of a scarcely distinct variety, Notropis venustus. In the Tennessee and Cumberland, and in the rivers of the Ozark range, is Notropis galacturus; and in the upper Arkansas Notropis camurus, - all distinct species of the same general type. Northward, in all the streams from the Potomac to the Oswego, and westward to the Des Moines and the Arkansas, occurs a single species of this type, Notropis whipplei. But this species is not known from any of the streams inhabited by any of the other species mentioned, although very likely it is the parent stock of them all. 
bays, thus finding every facility for transfer from river to river. There is a continuous inland passage in fresh or brackish waters, traversable by such fishes, from Chesapeake Bay nearly to Cape Fear; and similar conditions exist on the coasts of Louisiana, Texas, and much of Florida. In Perdido Bay I have found fresh-water Minnows ${ }^{1}$ and Silversides ${ }^{2}$ living together with marine Gobies ${ }^{3}$ and salt-water Eels. ${ }^{4}$ Fresh-water Alligator Gars ${ }^{5}$ and marine Sharks compete for the garbage thrown over from the Pensacola wharves. In Lake Pontchartrain the fauna is a remarkable mixture of fresh-water fishes from the Mississippi and marine fishes from the Gulf. Channel-cats, Sharks, Sea-crabs, Sun-fishes, and Mullets can all be found there together. It is therefore to be expected that the lowland fauna of all the rivers of the Gulf States would closely resemble that of the lower Mississippi; and this, in fact, is the case.

The streams of southern Florida and those of southwestern Texas offer some peculiarities connected with their warmer climate. The Florida streams contain a few peculiar fishes; ${ }^{6}$ while the rivers of Texas, with the same general fauna as those farther north, have also a few distinctly tropical types, ${ }^{7}$ immigrants from the lowlands of Mexico.

The fresh waters of Cuba are inhabited by fishes unlike those found in the United States. Some

I Notropis cercostigma; Notropis xanocephalus.
2 Labidesthes sicculus.
8 Gobiosoma molestum.
4 Myrophis punctatus.
5 Lepisosteus tristochus.

${ }_{6}^{6}$ Jordanella, Rivultus, Heterandria, etc.

7 Heros, Tetragonopterus. 
of these are evidently indigenous, derived in the waters they now inhabit directly from marine forms. Two of these are eyeless species, ${ }^{1}$ inhabiting streams in the caverns. They have no relatives in the fresh waters of any other region, the Blind-fishes ${ }^{2}$ of our caves being of a wholly different type. Some of the Cuban fishes are common to the fresh waters of the other West Indies. Of Northern types, only one, the Alligator Gar, ${ }^{3}$ is found in Cuba, and this is evidently a filibuster immigrant from the coasts of Florida.

The low and irregular water-shed which separates the tributaries of Lake Michigan and Lake Erie from those of the Ohio is of little importance in determining the range of species. Many of the distinctively Northern fishes are found in the headwaters of the Wabash and the Scioto. The considerable difference in the general fauna of the Ohio Valley as compared with that of the streams of Michigan is due to the higher temperature of the former region, rather than to any existing barriers between the river and the Great Lakes. In northern Indiana the water-shed is often swampy, and in many places large ponds exist in the early spring.

At times of heavy rains many species will move through considerable distances by means of temporary ponds and brooks. Fishes that have thus emigrated often reach places ordinarily inacces-

1 Lucifuga and Stygicola, fishes allied to the Cod, and belonging to the family of Brotulide.

2 Amblyopsis, Typhlichthys.

3 Lepisosteus tristochus. 
sible, and people finding them in such localities often imagine that they have "rained down." Once, near Indianapolis, after a heavy shower, I found in a furrow in a corn-field a small Pike, ${ }^{1}$ some half a mile from the creek in which he should belong. The fish was swimming along in a temporary brook, apparently wholly unconscious that he was not in his native stream. Migratory fishes, which ascend small streams to spawn, are especially likely to be transferred in this way. By some such means any of the water-sheds in Ohio, Indiana, or Illinois may be passed.

It is certain that the limits of Lake Erie and Lake Michigan were once more extended than now. It is reasonably probable that some of the territory now drained by the Wabash and the Illinois was once covered by the waters of Lake Michigan. The Cisco ${ }^{2}$ of Lake Tippecanoe, Lake Geneva, and the lakes of the Oconomowoc chain, is evidently a modified descendant of the so-called Lake Herring. ${ }^{3} \quad$ Its origin most likely dates from the time when these small deep lakes of Indiana and Wisconsin were connected with Lake Michigan. The changes in habits which the Cisco has undergone are considerable. The changes in external characters are but trifling. The presence of the Cisco in these lakes and its periodical disappearance - that is, retreat into deep water when not in the breeding season - has given rise to much nonsensical discussion as to whether any or all of.

\footnotetext{
1 Esox vermiculatus Le Sueur.

2 Coregonus artedi sisco, Jordan.

3 Coregonus artedi Le Sueur.
} 
these lakes are still joined to Lake Michigan by subterranean channels. Several of the larger fishes, properly characteristic of the Great Lake Region, ${ }^{1}$ are occasionally taken in the Ohio River, where they are usually recognized as rare stragglers. The difference in physical conditions is probably the sole cause of their scarcity in the Ohio basin.

The similarity of the fishes in the different streams and lakes of the Great Basin is doubtless to be attributed to the general mingling of their waters which took place during and after the glacial epoch. Since that period the climate in that region has grown hotter and drier, until the overflow of the various lakes into the Columbia basin through the Snake River has long since ceased. These lakes have become isolated from each other, and many of them have become salt or alkaline and therefore uninhabitable. In some of these lakes certain species may now have become extinct which still remain in others. In some cases, perhaps, the differences in surrounding may have caused divergence into distinct species of what was once one parent stock. The Suckers in Lake Tahoe ${ }^{2}$ and those in Utah Lake are certainly now different from each other and from those in the Columbia. The Trout ${ }^{3}$ in the same waters can be regarded as more or less tangible varieties only, while the White-fishes ${ }^{4}$ show no differences at all. The differences in the present

1 As, Lota lota maculosa; Percopsis guttatus ; Esox masquinongy.

2 Catostomus tahoensis, in Lake Tahoe; Catostomus macrocheilus and discololus, in the Columbia; Catostomus fecundus, Catostomus ardens; Chasmistes liorus and Pantosteus generosus, in Utah Lake.

3 Salmo mykiss, et vars. henshawi and virginalis.

4 Corcsonus williamsoni. 
faunæ of Lake Tahoe and Utah Lake must be chiefly due to influences which have acted since the glacial epoch, when the whole Utah Basin was part of the drainage of the Columbia.

Connected perhaps with changes due to glacial influences is the presence in the deep waters of the Great Lakes of certain marine types, ${ }^{1}$ as shown by the explorations of Professor Sidney I. Smith and others. One of these is a genus of fishes, ${ }^{2}$ of which the nearest allies now inhabit the Arctic Seas. In his review of the fish-fauna of Finland, ${ }^{3}$ Professor A. J. Malmgren finds a number of Arctic species in the waters of Finland which are not found either in the North Sea or in the southern portions of the Baltic. These fishes are said to " agree with their 'forefathers' in the Glacial Ocean in every point, but remain comparatively smaller, leaner, almost starved." Professor Lovén ${ }^{4}$ also has shown that numerous small animals of marine origin are found in the deep lakes of Sweden and Finland as well as in the Gulf of Bothnia. These anomalies of distribution are explained by Lovén and Malmgren on the supposition of the former continuity of the Baltic through the Gulf of Bothnia with the Glacial Ocean. During the second half of the glacial period, according to Lovén, "the greater part of Finland and of the

1 Species of Mysis and other genera of Crustaceans, similar to species described by Sars and others, in lakes of Sweden and Finland.

2 Triglopsis thompsoni Girard, a near ally of the marine species Acanthocottus quadricornis $\mathrm{L}$.

${ }^{3}$ Kritisk Öfversigt af Finlands Fisk-Fauna: Helsingfors, 1863.

4 See Günther, Zoological Record for 1864, p. 137. 
middle of Sweden was submerged, and the Baltic was a great gulf of the Glacial Ocean, and not connected with the German Ocean. By the gradual elevation of the Scandinavian Continent, the Baltic became disconnected from the Glacial Ocean, and the great lakes separated from the Baltic. In consequence of the gradual change of the salt water into fresh, the marine fauna became gradually extinct, with the exception of the glacial forms mentioned above."

It is possible that the presence of marine types in our Great Lakes is to be regarded as due to some depression of the land which would connect their waters with those of the Gulf of St. Lawrence. On this point, however, our data are still incomplete.

To certain species of upland or mountain fishes, the depression of the Mississippi basin itself forms a barrier which cannot be passed. The Blackspotted Trout, ${ }^{1}$ very closely related species of which abound in all waters of northern Asia, Europe, and western North America, has nowhere crossed the basin of the Mississippi, although one of its species finds no difficulty in passing Behring Strait. The Trout and White-fish of the Rocky Mountain region are all species different from those of the Great Lakes or the streams of the Alleghany system. To the Grayling, the Trout,

1 Salmo fario L., in Europe: Salmo labrax Pallas, etc, in Asia; Salmo gairdneri Richardson, in streams of the Pacific Coast. Salmo mykiss Walbaum, in Kamtschatka, Alaska, and throughout the Rocky Mountain range to the Mexican boundary, and the head-waters of the Kansas, Platte, and Missouri. 
the White-fish, the Pike, and to arctic and subarctic species generally, Behring Strait have evidently proved no serious obstacle to diffusion; and it is not unlikely that much of the close resemblance of the fresh-water faunæ of northern Europe, Asia, and North America is due to this fact. To attempt to decide from which side the first migration came in regard to each group of fishes might be interesting; but without a wider range of facts than is now in our possession, such attempts would be mere guesswork and without value. The interlocking of the fish-faunæ of Asia and North America presents, however, a number of interesting problems, for numerous migrations in both directions have doubtless taken place.

I could go on indefinitely with the discussion of special cases, each more or less interesting or suggestive in itself, but the general conclusion is in all cases the same. The present distribution of fishes is the result of the long-continued action of forces still in operation. The species have entered our waters in many invasions from the Old World or from the sea. Each species has been subjected to the various influences implied in the term " natural selection," and under varying conditions its representatives have undergone many different modifications. Each of the six hundred species we now know may be conceived as making every year inroads on territory occupied by other species. If these colonies are able to hold their own in the struggle for possession, they will multiply in the new conditions, and the range of the species becomes widened. If the surroundings are different, 
new species or varieties may be formed with time; and these new forms may again invade the territory of the parent species. Again, colony after colony of species after species may be destroyed by other species or by uncongenial surroundings.

The ultimate result of centuries on centuries of the restlessness of individuals is seen in the facts of geographical distribution. Only in the most general way can the history of any species be traced; but could we know it all, it would be as long and as eventful a story as the history of the colonization and settlement of North America by immigrants from Europe. But by the fishes each river in America has been a hundred times discovered, its colonization a hundred times attempted. In these efforts there is no co-operation. Every individual is for himself, every struggle a struggle of life and death; for each fish is a cannibal, and to each species each member of every other species is an alien and a savage. 


\section{AGASSIZ AT PENIKESE.}

OUIS AGASSIZ came to America in 1846,
while in the height of his European fame. He came to America partly because he wished to test on this continent his theory of the action of ice, partly because he desired to see for himself the mighty new land where "Nature is rich, but tools and workmen few, while traditions there are none." "He came," it was said, "in a spirit of adventure and curiosity. He stayed because he liked a country where he could think and act as he pleased."

His associates here were not more wise or more learned than his fellow-workers in Europe. $\mathrm{He}$ found, as others have found in America, many things which are crude or ridiculous or stupid. But there were other matters for which he cared more than for the advantages of European culture. $\mathrm{He}$ found in America the spirit of progress. $\mathrm{He}$ found a people not satisfied with present achievement, but continually striving for something better. He found that the desire of each generation was to know more and to be more than was possible with generations preceding. He believed that as a teacher in America his influence would be tenfold greater than it could possibly be in any of the universities of Germany or France. He could 
make his whole strength count, because no artificial barriers would come between him and the student.

From the time that Agassiz landed on our shores till his death, he became more and more intensely American. He was all the more American because his life in Europe had made him keenly alive to the evil effects of barriers of all sorts, social, political, economic, to all the thousand forms of injustice and oppression which accompany despotism or paternalism in government. The American idea of freedom in growth and equality in opportunity found in him an earnest apostle, and in the ultimate triumph of this idea he had never the slightest doubt.

He was above all else a teacher. His work in America was that of a teacher of science, - of science in the broadest sense as the orderly arrangement of the results of all human experience. He would teach men to know, not simply to remember or to guess. He believed that men in all walks of life would be more useful and more successful through the thorough development of the powers of observation and judgment. He believed that the sense of reality should be the central axis of human life. He would have the student trained through contact with real things, not merely exercised in the recollection of the book descriptions of things. "If you study Nature in books," he said, "when you go out of doors you cannot find her."

Agassiz was once asked to write a text-book in zoölogy for the use of schools and colleges. Of 
this he said: "I told the publishers that I was not the man to do that sort of thing, and I told them, too, that the less of that sort of thing which is done the better. It is not school-books we want, it is students. The book of Nature is always open, and all that I can do or say shall be to lead young people to study that book, and not to pin their faith to any other."

He taught natural history in Harvard College as no other man had taught in America before. He was the best beloved of teachers, because he was the most genial and kindly. Cambridge people used to say that one had "less need of an overcoat in passing Agassiz's house" than any other in that city. In the interest of popular education as well as of scientific research, Agassiz laid the foundation of the Museum of Comparative Zoölogy. Here, in the face of all sorts of discouragements, he worked with a wonderful zeal, - a zeal which showed its results in the prosperity of everything with which he had to do. Less energetic professors complained that Agassiz's department received too much attention. Even Emerson ventured to suggest, in one of his lectures in I864, that Harvard University was in danger of a onesided growth. To this criticism of Emerson Agassiz responded in a most characteristic personal letter. This letter gives the key-note of the modern idea of university development.

From this letter I quote a few paragraphs:"You say," says Agassiz, " that Natural History is getting too great an ascendency among us, that it is out of proportion to other departments, and 
you hint that a check-rein would not be amiss on the enthusiastic professor who is responsible for all this.

"Do you not see that the way to bring about a well-proportioned development of all the resources of the University is not to check the Natural History department, but to stimulate the others? Not that the Zoölogical school grows too fast, but that the others do not grow fast enough?

"This sounds invidious and somewhat boastful, but it is you and not I who have instituted the comparison. It strikes me that you have not hit upon the best remedy for this want of balance. If symmetry is to be obtained by cutting down the most vigorous growth, it seems to me that it would be better to have a little irregularity here and there. In stimulating by every means in my power the growth of the Museum and the means of education connected with it, I am far from having a selfish wish to see my own department tower above the others. I wish that every one of my colleagues would make it hard for me to keep up with him; and there are some among them, I am happy to say, who are ready to run a race with me."

In one of his addresses Agassiz said: -

"The physical suffering of humanity, the wants of the poor, the craving of the hungry and naked, appeal to the sympathy of every one who has a human heart. But there are necessities which only the destitute student knows; there is a hunger and thirst which only the highest charity can understand and relieve, and on this solemn occasion let me say that every dollar given for higher 
education in whatever department of knowledge is likely to have a greater influence on the future character of our nation than even the thousands and hundred thousands and millions which we have already spent and are spending to raise the many to material ease and comfort."

Of the older teachers of biology in America, the men who were born between 1825 and I850, nearly all who have reached eminence have been at one time or another pupils of Agassiz. The names of LeConte, Hartt, Shaler, Scudder, Wilder, Hyatt, Putnam, Packard, Clark, Alexander Agassiz, Morse, Brooks, Whitman, Minot, Garman, Faxon, Fewkes, James, Niles, and many others not less worthily known, come to our thoughts at once as evidence of this statement, as well as those of Steindachner, J. A. Allen, Dall, Uhler, Marcou, Bickmore, Lyman, Girard, Ordway, St. John, Anthony, and others who have won celebrity in scientific work outside the class-room. Those naturalists who, like Gray, Dana, Baird, Lesley, Kirtland, Engelmann, Wachsmuth, Hagen, Lesquereux, Stimpson, and others, were not pupils, were associates and friends.

Even as late as 1873, when Agassiz died, the Museum of Comparative Zoölogy was almost the only school in America where the eager student of natural history could find the work he wanted. The colleges generally taught only the elements of any of the sciences. Twenty years ago original research was scarcely considered as among the functions of the American college. Such investigators as America had were for the most part 
outside of the colleges, or at the best carrying on their investigations in time stolen from the drudgery of the class-room. One of the greatest of American astronomers was kept for forty years teaching algebra and geometry, with never a student far enough advanced to realize the real work of his teacher; and this case was typical of hundreds before the university spirit was kindled in American schools. That this spirit was kindled in Harvard forty years ago was due in the greatest measure to Agassiz's influence. It was here that graduate instruction in science in America practically began. In an important sense the Museum of Comparative Zoölogy was the first American university.

Notwithstanding the great usefulness of the Museum and the broad influence of its teachers, Agassiz was not fully satisfied. The audience he reached was still too small. Throughout the country the great body of teachers of science went on in the old mechanical way. On these he was able to exert no influence. The boys and girls still kept up the humdrum recitations from worthless text-books. They got their lessons from the book, recited them from memory, and no more came into contact with Nature than they would if no animals or plants or rocks existed on this side of the planet Jupiter. It was to remedy this state of things that Agassiz conceived, in 1872 , the idea of a scientific "camp-meeting," where the workers and the teachers might meet together, - a summer school of observation, where the teachers should be trained to see Nature for themselves and teach others how to see it. 
The first plan suggested was that of calling the teachers of the country together for a summer outing on the island of Nantucket. Before the site was chosen, Mr. John Anderson, a wealthy tobaccomerchant in New York City, offered to Agassiz the use of his island of Penikese, and an endowment of fifty thousand dollars in money, if he would permanently locate this scientific "camp-meeting" on the island. To this gift Mr. C. W. Galloupe, of Boston, added the use of his large yacht, the "Sprite." Thus was founded the Anderson School of Natural History on the island of Penikese.

Penikese is a little island containing about sixty acres of very rocky ground, a pile of stones with intervals of soil. It is the last and least of the Elizabeth Islands, lying to the south of Buzzard's Bay, on the south coast of Massachusetts. The whole cluster was once a great terminal moraine of rocks and rubbish of all sorts, brought down from the mainland by some ancient glacier, and by it dropped into the ocean off the heel of Cape Cod. The sea has broken up the moraine into eight little islands by wearing tide channels between hill and hill. The names of these islands are recorded in the jingle which the children of that region learn before they go to school, -

"Naushon, Nonamesset, Uncatena, and Wepecket,

Nashawena, Pesquinese, Cuttyhunk, and Penikese."

And Penikese, last and smallest of them, lies, a little forgotten speck, out in the ocean, eighteen miles south of New Bedford. It contained two hills, joined together by a narrow isthmus, a little har- 
bor, a farm-house, a flag-staff, a barn, a willow-tree, and a flock of sheep. And here Agassiz founded his school. This was in the month of June in the year 1873 .

From the many hundred applicants who sent in their names as soon as the plan was made public Agassiz chose fifty, - about thirty men and twenty women - teachers, students, and naturalists of various grades from all parts of the country. This practical recognition of coeducation was criticised by many of Agassiz's friends, trained in the monastic schools of New England; but the results justified his decision. It was his thought that these fifty teachers should be trained as well as might be in right methods of work. They should carry into their schools his own views of scientific teaching. Then each of these schools would become in its time a centre of help to others, until the influence toward real work in science should spread throughout our educational system.

None of us will ever forget his first sight of Agassiz. We had come down from New Bedford in a little tug-boat in the early morning, and Agassiz met us at the landing-place on the island. He was standing almost alone on the little wharf, and his great face beamed with pleasure. For this summer school, the thought of his old age, might be the crowning work of his lifetime. Who could foresee what might come from the efforts of fifty men and women, teachers of science, each striving to do his work in the most rational way? His thoughts and hopes rose to expectations higher than any of us then understood. 
His tall, robust figure, his broad shoulders bending a little under the weight of years, his large round face lit up by kindly dark-brown eyes, his cheery smile, the enthusiastic tones of his voice, his rolling gait, like that of " a man who had walked much over ploughed ground," - all these entered into our first as well as our last impressions of Agassiz. He greeted us with great warmth as we landed. He looked into our faces to justify himself in making choice of us among the many whom he might have chosen.

The roll of the Anderson School has never been published, and I can only restore a part of it from memory. Among those whose names come to my mind as I write are Dr. Charles O. Whitman, of the University of Chicago; Dr. William K. Brooks, of Johns Hopkins; Dr. Frank H. Snow, now Chancellor of the University of Kansas; Dr. W. O. Crosby, of the Boston Society of Natural History; Charles Sedgwick Minot, Samuel Garman, Walter Faxon, J. Walter Fewkes, - all of these still connected with the work at Cambridge; Ernest Ingersoll, then just beginning his literary work; Professor J. G. Scott, of the Normal School at Westfield; Professor Stowell, of the school at Cortland; Professor Austin C. Apgar, of Trenton, N. J.; Professor Fernald, of Maine; Miss Susan Hallowell, of Wellesley College; Miss Mary A. Beaman (now Mrs. Joralemon, of the Belmont School, California); Mr. E. A. Gastman, of Illinois, and other well-known instructors. With these was the veteran teacher of botany at Mount Holyoke Seminary, Lydia W. Shattuck, with her 
pupil and associate, Susan Bowen. Professor H. H. Straight and his bride, both then teachers in the State Normal School at Oswego, were also with us. These four, whom all of us loved and respected, were the first of our number to be claimed by death.

Among our teachers, besides Agassiz, were Burt G. Wilder, Edward S. Morse, Alfred Mayer, Frederick W. Putnam, then young men of growing fame, with Arnold Guyot and Count Pourtalès, early associates of Agassiz, already in the fulness of years. Mrs. Agassiz was present at every lecture, note-book in hand; and her genial personality did much to bind the company together.

The old barn on the island had been hastily converted into a dining-hall and lecture-room. A new floor had been put in; but the doors and walls remained unchanged, and the swallows' nests were undisturbed under the eaves. The sheep had been turned out, the horse-stalls were changed to a kitchen, and on the floor of the barn, instead of the hay-wagon, were placed three long tables. At the head of one of these sat Agassiz. At his right hand always stood a movable blackboard, for he seldom spoke without a piece of chalk in his hand. He would often give us a lecture while we sat at the table, frequently about some fish or other creature the remains of which still lay on our plates.

Our second day upon the island was memorable above all others. Its striking incident has passed into literature in the poem of Whittier: "The Prayer of Agassiz."

When the morning meal was over, Agassiz arose 
in his place and spoke, as only he could speak, of his purpose in calling us together. The swallows flew in and out of the building in the soft June air, for they did not know that it was no longer a barn but a temple. Some of them almost grazed his shoulder as he spoke to us of the needs of the people for truer education. He told us how these needs could be met, and of the results which might come to America from the training and consecration of fifty teachers. This was to him no ordinary school, still less an idle summer's outing, but a mission work of the greatest importance. He spoke with intense earnestness, and all his words were filled with that deep religious feeling so characteristic of his mind. For to Agassiz each natural object was a thought of God, and trifling with God's truth as expressed in Nature was the basest of sacrilege.

What Agassiz said that morning can never be said again. No reporter took his language, and no one could call back the charm of his manner or the impressiveness of his zeal and faith. At the end he said, "I would not have any man to pray for me now," and that he and each of us would utter his own prayer in silence. What he meant by this was that no one could pray in his stead. No public prayer could take the place of the prayer which each of us would frame for himself. Whittier says:-

"Even the careless heart was moved,

And the doubting gave assent

With a gesture reverent

To the Master well beloved. 
As thin mists are glorified

By the light they cannot hide, All who gazed upon him saw, Through its veil of tender awe, How his face was still uplit By the old sweet look of it, Hopeful, trustful, full of cheer And the love that casts out fear."

And the summer went on, with its succession of joyous mornings, beautiful days, and calm nights, with every charm of sea and sky; the master with us all day long, ever ready to speak words of help and encouragement, ever ready to give us from his own stock of learning. The boundless enthusiasm which surrounded him like an atmosphere, and which sometimes gave the appearance of great achievement to the commonest things, was never lacking. He was always an optimist, and his strength lay largely in his realization of the value of the present moment. He was a living illustration of the aphorism of Thoreau, that " there is no hope for you unless the bit of sod under your feet is the sweetest in this world - in any world." The thing he had in hand was the thing worth doing, and the men about him were the men worth helping.

He was always picturesque in his words and his work. He delighted in the love and approbation of his students and his friends, and the influence of his personality sometimes gave his opinions weight beyond the value of the investigations on which they were based. With no other investigator have the work and the man been so identified as with Agassiz. No other of the great workers has been equally great as a teacher. His greatest work in 
science was his influence on other men. He was a constant stimulus and inspiration.

In an old note-book of those days I find fragments of some of his talks to teachers at Penikese. From this note-book I take some paragraphs, just as I find them written there:-

"Never try to teach what you do not yourself know and know well. If your school board insist on your teaching anything and everything, decline firmly to do it. It is an imposition alike on pupils and teacher to teach that which he does not know. Those teachers who are strong enough should squarely refuse to do such work. This muchneeded reform is already beginning in our colleges, and I hope it will continue. It is a relic of mediæval times, this idea of professing everything. When teachers decline work which they cannot do well, improvements begin to come in. If one would be a successful teacher, he must firmly refuse work which he cannot do well. It is a false idea to suppose that everybody is competent to learn or to teach everything. Would our great artists have succeeded equally well in Greek or calculus? A smattering of everything is worth little. It is a fallacy to suppose that an encyclopædic knowledge is desirable. The mind is made strong, not through much learning, but by the thorough possession of something."

"Lay aside all conceit. Learn to read the book of Nature for yourself. Those who have succeeded best have followed for years some slim thread which once in a while has broadened out and disclosed some treasure worth a life-long search." 
"A man cannot be professor of zoölogy on one day and of chemistry on the next, and do good work in both. As in a concert all are musicians, one plays one instrument, and one another, but none all in perfection."

"You cannot do without one specialty. You must have some base-line to measure the work and attainments of others. For a general view of the subject, study the history of the sciences. Broad knowledge of all Nature has been the possession of no naturalist except Humboldt, and general relations constituted his specialty."

"Select such subjects that your pupils cannot walk out without seeing them. Train your pupils to be observers, and have them provided with the specimens about which you speak. If you can find nothing better, take a house-fly or a cricket, and let each one hold a specimen and examine it as you talk."

"In I847 I gave an address at Newton, Mass., before a Teachers' Institute conducted by Horace Mann. My subject was grasshoppers. I passed around a large jar of these insects, and made every teacher take one and hold it while I was speaking. If any one dropped the insect, I stopped till he picked it up. This was at that time a great innovation, and excited much laughter and derision. There can be no true progress in the teaching of natural science until such methods become general."

"There is no part of the country where in the summer you cannot get a sufficient supply of the best specimens. Teach your children to bring 
them in for themselves. Take your text from the brooks, not from the booksellers. It is better to have a few forms well known than to teach a little about many hundred species. Better a dozen specimens thoroughly studied as the result of the first year's work, than to have two thousand dollars' worth of shells and corals bought from a curiosityshop. The dozen animals would be your own."

"You ${ }^{1}$ will find the same elements of instruction all about you wherever you may be teaching. You can take your classes out and give them the same lessons, and lead them up to the same subjects you are yourselves studying here. And this method of teaching children is so natural, so suggestive, so true. That is the charm of teaching from Nature herself. No one can warp her to suit his own views. She brings us back to absolute truth as often as we wander."

"The study of Nature is an intercourse with the highest mind. You should never trifle with Nature, At the lowest her works are the works of the highest powers, the highest something in whatever way we may look at it."

"A laboratory of natural history is a sanctuary where nothing profane should be tolerated. I feel less agony at improprieties in churches than in a scientific laboratory."

"In Europe I have been accused of taking my scientific ideas from the Church. In America I have been called a heretic, because I will not let my church-going friends pat me on the head."

I In this paragraph, quoted by Mrs. Agassiz (Life and Letters of Agassiz, p. 775), I have adopted the wording as given by her. 
Of all these lectures the most valuable and the most charming were those on the glaciers. In these the master spoke, and every rock on our island was a mute witness to the truth of his words. Equally charming were the reminiscences of his early life and of his fellow-workers in science, Schimper and Braun in Munich, Valenciennes and the rest in Paris, and of the three men he acknowledged as masters, Cuvier, Humboldt, and Döllinger. "I lived at Munich," he once said, "for three years under Dr. Döllinger's roof, and my scientific training goes back to him and to him alone."

He often talked to us of the Darwinian theory, to which in all its forms he was most earnestly opposed. Agassiz was essentially an idealist. All his investigations were to him, not studies of animals or plants as such, but of the divine plans of which their structures are the expression. "That earthly form was the cover of spirit was to him a truth at once fundamental and self-evident." The work of the student was to search out the thoughts of God, and as well as may be to think them over again. To Agassiz these divine thoughts were especially embodied in the relations of animals to each other. The species was the thoughtunit, the individual reproduction of the thought in the divine mind at the moment of the creation of the first one of the series which represents the species. The marvel of the affinity of structure of unity of plan in creatures widely diverse in habits and outward appearance - was to him a result of the association of ideas in the divine mind, 
an illustration of divine many-sidedness. To Darwin these same relations would illustrate the force of heredity acting under diverse conditions of environment. The sufficiency of his own philosophy Agassiz never doubted. In this confidence in his own mind and its resources, lay much of his strength and his weakness.

Agassiz had no sympathy with the prejudices worked upon by weak and foolish men in opposition to Darwinism. He believed in the absolute freedom of science; that no power on earth can give answers beforehand to the questions which men of science endeavor to solve. Of this I can give no better evidence than the fact that every one of the men specially trained by him has joined the ranks of the evolutionists. He would teach them to think for themselves, not to think as he did.

The strain of the summer was heavier than we knew. Before the school was closed for the season, those who were nearest him felt that the effort was to be his last. His physician told him that he must not work, must not think. But all his life he had done nothing else. To stop was impossible, for with his temperament there was the sole choice between activity and death.

And in December the end came. In the words of one of his old students, Theodore Lyman, "We buried him from the chapel that stands among the college elms. The students laid a wreath of laurel on his bier, and their manly voices sang a requiem. For he had been a student all his life long, and when he died he was younger than any of them." 
The next summer, the students of the first year came together at Penikese, and many eager new men were with them. Notable among these were Herbert E. Copeland, the ichthyologist, whose brilliant record was soon cut short by death; William R. Dudley, the botanist, and the anatomist Balfour H. Van Vleck. Wise and skilful teachers were present; but Agassiz was not there; and the sense of loss was felt above everything else. We met one evening in the lecture hall, and each one said the best that he could of the Master. The words that lasted longest with us were these of Samuel Garman, that "he was the best friend that ever student had." There could be no truer word nor nobler epitaph. We put on the walls these mottoes, written on cloth, and taken from Agassiz's lectures:-

Study Nature, not Books.

BE NOT AFRAID TO SAY, "I DO NOT kNOW." STRIVE TO INTERPRET WHAT REALLY EXISTS.

A LABORATORY is a SANCTUARY Which NOTHING PROFANE SHOULD ENTER.

These mottoes remained for fifteen years ${ }^{1}$ on the walls of the empty building, whence they were carried as precious relics to the Laboratory at Wood's Hole, which has been the lineal descendant of the school at Penikese.

At the end of the summer the authorities of the Museum closed the doors of the Anderson School forever. They ${ }^{2}$ had no choice in the matter, for

1 This is given on the authority of Dr. Carl H. Eigenmann.

2 Jules Marcou says (Life, Letters, and Works of Louis Agassiz, vol. ii. p. 207): "The Anderson School of Natural History" 
no college could be found which would spare the small sum needed for its maintenance. No rich men came forward as others had done in the past, men who would not stand by "to see so brave a man struggle without aid." For nearly twenty years the buildings stood on the island just as we had left them in 1874; an old sea-captain in charge of them until the winter of I89I, when he was drowned in a storm. A year or two later the buildings were burned to the ground, perhaps by lightning.

But while the island of Penikese is deserted, the impulse which came from Agassiz's work there still lives, and is felt in every field of American science. With all appreciation of the rich streams which in late years have come to us from many sources, and especially from the deep insight and resolute truthfulness of Germany, it is still true that the school of all schools which has had most influ-

at Penikese Island did not survive long after Agassiz's death. The appeals for aid addressed by Mr. Alexander Agassiz to the superintendents of public institutions and presidents of State Boards of Education of the several States did not find the ready response necessary for the support of the school ; and the Anderson School was soon a thing of the past. But if its existence was ephemeral, it set a most beneficial example, soon followed by permanent schools of the same sort . . . first those at Wood's Hole, Mass., one under the clirection of the United States Fish Commission, the other directed by Mr. C. O. Whitman; second one at Aunisquam, and afterwards at several other places on the Atlantic and Pacific Coasts under the direction of the Johns Hopkins University, the State University of California, and the Leland Stanford, Jr., University, while Mr. Alexander Agassiz . . . has since built a fine laboratory at Castle Hill . . . where researches on living marine animals are made every summer under his direction and at his expense." 
ence on scientific teaching in America, was held in an old barn on an uninhabited island some eighteen miles from the shore. It lasted but three months, and in effect it had but one teacher. The school at Penikese existed in the personal presence of Agassiz; when he died, it vanished! 


\section{AN ECCENTRIC NATURALIST.}

$\mathrm{T}^{\mathrm{T}}$ is now nearly seventy years since the first 1 student of our Western fishes crossed the Falls of the Ohio and stood on Indiana soil. He came on foot, with a note-book in one hand and a hickory stick in the other, and his capacious pockets were full of wild-flowers, shells, and toads. $\mathrm{He}$ wore " a long, loose coat of yellow nankeen, stained yellower by the clay of the roads, and variegated by the juices of plants." In short, in all respects of dress, manners, and appearance, he would be described by the modern name of "tramp." Nevertheless, no more remarkable figure has ever appeared in the annals of Indiana or in the annals of science. To me it has always possessed a peculiar interest; and so, for a few moments, I wish to call up before you the figure of Rafinesque, with his yellow nankeen coat, " his sharp tanned face, and his bundle of plants, under which a pedler would groan," before it recedes into the shadows of oblivion.

Constantine Samuel Rafinesque was born in Constantinople in the year I784. His father was a French merchant from Marseilles doing business in Constantinople, and his mother was a German girl, born in Greece, of the family name of Schmaltz. Rafinesque himself, son of a Franco-Turkish father 
and a Græco-German mother, was an American. Before he was a year old his life-long travels began, his parents visiting ports of Asia and Africa on their way to Marseilles. As a result of this trip, we have the discovery, afterward characteristically announced by him to the world, that "infants are not subject to sea-sickness." At Marseilles his future career was determined for him; or, in his own language: "It was among the flowers and fruits of that delightful region that I first began to enjoy life, and I became a botanist. Afterward, the first prize I received in school was a book of animals, and I am become a zoölogist and a naturalist. My early voyage made me a traveller. Thus, some accidents or early events have an influence on our fate through life, or unfold our inclinations." 1

Rafinesque read books of travel, those of Captain Cook, Le Vaillant, and Pallas especially; and his soul was fired with the desire "to be a great traveller like them. ... And I became such," he adds tersely. At the age of eleven he had begun an herbarium, and had learned to read the Latin in which scientific books of the last century were written. "I never was in a regular college," he says, "nor lost my time on dead lan. guages; but I spent it in reading alone, and by reading ten times more than is read in the schools. I have undertaken to read the Latin and Greek, as

1 This and most of the other verbal quotations in this paper are taken from an "Autobiography of Rafinesque," of which a copy exists in the Library of Congress. A few quotations have been somewhat abridged. 
well as the Hebrew, Sanskrit, Chinese, and fifty other languages, as I felt the need or inclination to study them." At the age of twelve he published his first scientific paper, "Notes on the Apennines," as seen from the back of a mule on a journey from Leghorn to Genoa. Rafinesque was now old enough to choose his calling in life. He decided to become a merchant; for, said he, "commerce and travel are linked." At this time came the first outbreaks of the French Revolution, when the peasants of Provence began to dream of " castles on fire and castles combustible ;" so Rafinesque's prudent father sent his money out of France and his two sons to America.

In Philadelphia, Constantine Rafinesque became a merchant's clerk, and his spare time was devoted to the study of botany. He tried also to study the birds; but he says, "The first bird I shot was a poor chickadee, whose death appeared a cruelty, and I never became much of a hunter." During his vacations Rafinesque travelled on foot over parts of Pennsylvania and Virginia. He visited President Jefferson, who, he tells us, asked him to call again. In 1805 , receiving an offer of business in Sicily, Rafinesque returned to Europe. $\mathrm{He}$ spent ten years in Sicily, - the land, as he sums it up, "of fruitful soil, delightful climate, excellent productions, perfidious men, and deceitful women." Here in Sicily he discovered the medicinal squill, which, aided by the equally medicinal paregoric, was once a great specific for all childish ailments. $\mathrm{He}$ commenced gathering this in large quantities for shipment to England and Russia. The Sici- 
lians thought that he was using it as a dye-stuff; " and this," said he, "I let them believe." Nearly two hundred thousand pounds had been shipped by him before the secret of the trade was discovered, since which time the Sicilians have prosecuted the business on their own account. He began to turn his attention to the animals of the sea, and here arose his passion for ichthyology. The red-shirted Sicilian fishermen used to bring to him the strange creatures which came in their nets. In i8 Io he published two works on the fishes of Sicily, and for our first knowledge of very many of the Mediterranean fishes we are indebted to these Sicilian papers of Rafinesque. It is unfortunately true, however, that very little real gain to science has come through this knowledge. Rafinesque's descriptions in these works are so brief, so hasty, and so often drawn from memory, that later naturalists have been put to great trouble in trying to make them out. A peculiar, restless, impatient enthusiasm is characteristic of all his writings, - the ardor of the explorer without the patience of the investigator. ${ }^{1}$

In Sicily, Rafinesque was visited by the English ornithologist, William Swainson. Swainson seems to have been a great admirer of "the eccentric naturalist," as he called him. Of him Rafinesque says: "Swainson often went with me to the mountains. He carried a butterfly-net to catch insects

1 Dr. Elliott Coues has wittily suggested that as the words "grotesque," "picturesque," and the like, are used to designate certain literary styles, the adjective "rafinesque" may be similarly employed for work like that of the author now under consideration. 
with, and was taken for a crazy man or a wizard. As he hardly spoke Italian, I had once to save him from being stoned out of a field, where he was thought to seek a treasure buried by the Greeks." Rafinesque now invented a new way of distilling brandy. He established a brandy-distillery, where, said he, "I made a very good brandy, equal to any made in Spain, without ever tasting a drop of it, since I hate all strong liquors. This prevented me from relishing this new employment, and so I gave it up after a time."

Finally, disgust with the Sicilians and fear of the French wars caused Rafinesque, who was, as he says, "a peaceful man," to look again toward the United States. In I8I5 he sailed again for America, with all his worldly goods, including his reams of unpublished manuscripts, his bushels of shells, and a multitude of drawings of objects in natural history. According to his own account, the extent of his collections at that time was enormous, and from the great number of scattered treatises on all manner of subjects which he published in later years, whenever he could get them printed, it is fair to suppose that his pile of manuscripts was equally great. A considerable number of his note-books, and of papers for which, fortunately for scientific nomenclature, he failed to find a publisher, are now preserved in the United States National Museum. These manuscripts are remarkable for two things, - the beauty of the quaint French penmanship, and the badness of the accompanying drawings. His numerous note-books, written in French, represent each the observations 
of a busy summer; and these observations, for the most part unchecked by the comparison of specimens, he prepared for the press during the winter. To this manner of working, perhaps unavoidable in his case, many of Rafinesque's errors and blunders are certainly due. In one of these note-books I find, among a series of notes in French, the following remarkable observation in English: "The girls at Fort Edward eat clay!" In another place I find a list of the new genera of fishes in Cuvier's "Règne Animal” (18I7) which were known to him. Many of these are designated as synonymous with genera proposed by Rafinesque in his "Caratteri" in 1810 . With this list is the remark that these genera of Cuvier are identical with such and such genera "proposed by me in I8 Io, but don't you tell it!"

Rafinesque was six months on the ocean in this second voyage to America. Finally, just as the ship was entering Long Island Sound, the pilot let her drift against one of the rocks which lie outside of the harbor of New London. The vessel filled and sank, giving the passengers barely time to escape with their lives. "I reached New London at midnight," says Rafinesque, "in a most deplorable situation. I had lost everything, - my fortune, my share in the cargo, my collections and labors of twenty years past, my books, my manuscripts, and even my clothes, - all I possessed, except some scattered funds and some little insurancemoney. Some hearts of stone have since dared to doubt of these facts, or rejoice at my losses. Yes, I have found men vile enough to laugh with- 
out shame at my misfortunes, instead of condoling with me. But I have met also with friends who have deplored my loss and helped me in need."

I shall pass rapidly over Rafinesque's career until his settlement in Kentucky. He travelled widely in America, in the summer, always on foot. "Horses were offered to me," he said, "but I never liked riding them, and dismounting for every flower. Horses do not suit botanists." He now came westward, following the course of the Ohio, and exploring for the first time the botany of the country. He came to Indiana, and for a short time was associated with the community then lately established by Owen and Maclure at New Harmony on the Wabash. Though this New Harmony experiment was a failure, as all communities must be in which the drone and the worker alike have access to the honey-cells, yet the debt due it from American science is very great. Although far in the backwoods, and in the long notorious county of Posey, New Harmony was for a time fairly to be called the centre of American science; and even after half a century has gone by its rolls bear few names brighter than those of Thomas Say, David Dale Owen, and Charles Albert Le Sueur.

Rafinesque soon left New Harmony, and became Professor of Natural History and the Modern Languages in Transylvania University, at Lexington, Kentucky. He was, I believe, the very first teacher of natural history in the West, and his experiences were not more cheerful than those of most pioneers. They would not give him at 
Lexington the degree of Master of Arts, he says, "because I had not studied Greek in a college, although I knew more languages than all the American colleges united. But it was granted at last; but that of Doctor of Medicine was not granted, because I would not superintend anatomical dissections." He continues:-

"Mr. Holley, the president of the university, despised and hated the natural sciences, and he wished to drive me out altogether. To evince his hatred against science and its discoveries, he had broken open my rooms in my absence, given one to the students, and thrown all my effects, books, and collections into the other. He had deprived me of my situation as librarian, and tried to turn me out of the college. I took lodgings in town, and carried there all my effects, leaving the college with curses both on it and Holley, which reached them both soon after ; for Holley died of the yellow fever in New Orleans and the college was burned with all its contents."

In one of his summer trips Rafinesque became acquainted with Audubon, who was then painting birds and keeping a little "grocery-store" down the river, at Henderson, Kentucky. Rafinesque reached Henderson in a boat, carrying on his back a bundle of plants which resembled dried clover. He accidentally met Audubon, and asked him to tell him where the naturalist lived. The ornithologist introduced himself, and Rafinesque handed him a letter from a friend in the East, commending him to Audubon as an "odd fish, which might not be described in the published treatises." The story of the interview is thus described by Audubon: 
" $\mathrm{His}$ attire struck me as exceedingly remarkable. A long, loose coat of yellow nankeen, much the worse for the many rubs it had got in its time, hung about him loosely, like a sack. A waistcoat of the same, with enormous pockets and buttoned up to the chin, reached below over a pair of tight pantaloons, the lower part of which was buttoned down over his ankles. His beard was long, and his lank black hair hung loosely over his shoulders. His forehead was broad and prominent, indicating a mind of strong power. His words impressed an assurance of rigid truth; and as he directed the conversation to the natural sciences, I listened to him with great delight.

"That night, after we were all abed, I heard of a sudden a great uproar in the naturalist's room. I got up and opened the door, when to my astonishment I saw my guest running naked, holding the handle of my favorite Cremona, the body of which he had battered to pieces in attempting to kill the bats which had entered the open window! I stood amazed; but he continued jumping and running around and around till he was fairly exhausted, when he begged me to procure one of the animals for him, as he felt convinced that they belonged to a new species. Although I was convinced of the contrary, I took up the bow of my demolished violin, and giving a smart tip to each bat as it came up, we soon had specimens enough."

A part of the story of this visit, which Audubon does not tell, may be briefly related here: Audubon was a great artist, and his paintings of birds and flowers excited the wonder and admiration of Rafinesque, as it has that of the generations since his time. But Audubon was something of a wag withal, and some spirit of mischief led him to revenge the loss of his violin on the too ready credulity of his guest. He showed him gravely 
some ten grotesque drawings of impossible fishes which he had observed "down the river," with notes on their habits, and a list of the names by which they were known by the French and English settlers. These Rafinesque duly copied into his note-books, and later he published descriptions of them as representatives of new genera, such as Pogostoma, Aplocentrus, Litholepis, Pilodictis, Pomacampsis, and the like.

These singular genera, so like and yet so unlike to anything yet known, have been a standing puzzle to students of fishes. Various attempts at identification of them have been made, but in no case have satisfactory results been reached. Many of the hard things which have been said of Rafinesque's work rest on these unlucky genera, " " communicated to me by Mr. Audubon." The true story of this practical joke was told me by the venerable Dr. Kirtland, who in turn received it from Dr. Bachman, the brother-in-law and scientific associate of Audubon. In the private note-books of Rafinesque I have since found his copies of these drawings, and a glance at these is sufficient to show the extent to which science through him has been victimized.

About this time Rafinesque turned his mind again toward invention. He invented the present arrangement of coupon bonds, or, as he called it, "the divitial invention." Savings-banks were pro-

i I am informed by Dr. J. A. Allen that there are also some unidentified genera of herons, similarly described by Rafinesque from drawings kindly shown him by Mr. Audubon. Apparently these also date from the same unlucky practical joke. 
jected by him, as well as "steam ploughs," “ aquatic railroads," fire-proof houses, and other contrivances which he was unable to perfect. He took much delight in the study of the customs and languages of the Indians. In so doing, if the stories are true, he became, in a way, associated with the origin of Mormonism; for it is said that his theory that the Indians came from Asia by way of Siberia, and were perhaps the descendants of the ten lost tribes of Israel, gave the first suggestion to Solomon Spaulding for his book of the prophet Mormon. In any case, whether this be true or not, it is certain that Rafinesque is still cited as high authority by the Latter-Day Saints when the genuineness of the book of Mormon is questioned.

Rafinesque now returned to Philadelphia, and published "The Atlantic Journal and Friend of Knowledge," "Annals of Nature," and other serials, of which he was editor, publisher, and usually sole contributor. After a time he became sole subscriber, also, - a condition of affairs which greatly exasperated him against the Americans and their want of appreciation of science. He published several historical treatises, and contemplated a "Complete History of the Globe," with all its contents. An elaborate poem of his, dreary enough, is entitled "The World ; or, Instability." He made many enemies among the American botanists of his time by his overbearing ways, his scorn of their customs and traditions, and especially by his advocacy of crude and undigested though necessary. reforms, so that at last most of them decided to ignore his very existence. In those days, in 
matters of classification, the rule of Linnæus was supreme, and any effort to recast his artificial groupings was looked at as heretical in the extreme. The attempt at a natural classification of plants, which has made the fame of Jussieu, had the full sympathy of Rafinesque; but to his American contemporaries such work could lead only to confusion. Then, again, in some few of its phases, Rafinesque anticipated the modern doctrine of the origin of spccies. That the related species of such genera as Rosa, Quercus, Trifolium, have had a common origin, - a view the correctness of which no well-informed botanist of our day can possibly doubt, - Rafinesque then maintained against the combined indignation and disgust of all his fellowworkers. His writings on these subjects read better to-day than when, forty-fye years ago, they were sharply reviewed by one of our then young . and promising botanists, Dr. Asa Gray.

But the botanists had good reason to complain of the application of Rafinesque's theories of evolution. To him, the production of a new species was a rapid process, - a hundred years was time enough, - and when he saw the tendency in diverging varieties toward the formation of new species, be was eager to anticipate Nature (and his fellow-botanists as well), and give it a new name. He became a monomaniac on the subject of new species. He was uncontrolled in this matter by the influence of other writers, - that incredulous conservatism as to another's discoveries which furnishes a salutary balance to enthusiastic workers. Before his death so much had 
he seen, and so little had he compared, that he had described certainly twice as many fishes, and probably ncarly twice as many plants and shell, as really existed in the regions over which he travelled. He once sent for publication a paper seriously describing, in regular natural history style, twelve new species of thunder and lightning which he had observed near the Falls of the Ohio.

Then, too, Rafinesque studied in the field, collecting and observing in the summer, comparing and writing in the winter. When one is chasing a frog in a canebrake, or climbing a cliff in search of a rare flower, he cannot have a library and a museum at his back. The exact work of our modern museums and laboratories was almost unknown in his day. Then, again, he depended too much on his memory for facts and details; and, as Professor Agassiz used to say, "the memory must not be kept too full, or it will spill over."

Thus it came about that the name and work of Rafinesque fell into utter neglect. His writings, scattered here and there in small pamphlets, cheap editions published at his own expense, had been sold as paper-rags, or used to kindle fires by those to whom they were sent, and later authors could not find them. His "Ichthyologia Ohiensis," once sold for a dollar, is now quoted at fifty dollars, and the present writer has seen but two copies of it. In the absence of means to form a just opinion of his work, it became the habit to pass him by with a sneer, as the "inspired idiot ... whose fertile imagination has peopled the waters of the Ohio." Until lately, only Professor Agas- 
$\operatorname{siz}^{1}$ has said a word in mitigation of the harsh verdict passed on Rafinesque by his fellow-workers and their immediate successors. Agassiz says, very justly:-

"I am satisfied that Rafinesque was a better man than he appeared. His misfortune was his prurient desire for novelties, and his rashness in publishing them. . . Tracing his course as a naturalist during his residence in this country, it is plain that he alarmed those with whom he had intercourse, by his innovations, and that they preferred to lean upon the authority of the great naturalist of the age [Cuvier], who, however, knew little of the special history of the country, rather than to trust a somewhat hasty man who was living among them, and who had collected a vast amount of information from all parts of the States upon a variety of subjects then entirely new to science." 2

In a sketch of "A Neglected Naturalist," Professor Herbert E. Copeland has said:-

"To many of our untiring naturalists, who sixty years ago accepted the perils and privations of the far West, to collect and describe its animals and plants, we have given the only reward they sought, - a grateful remembrance of their work. Audubon died full of riches and honor, with the knowledge that his memory would be cherished as long as birds should sing. Wilson is the 'father of American ornithology,' and his mistakes and faults are forgotten

1 So early as I844, Professor Agassiz wrote to Charles Lucien Bonaparte: "I think that there is a justice due to Rafinesque. However poor his descriptions, he first recognized the necessity of multiplying genera in ichthyology, and this at a time when the thing was far more difficult than now."

2 Agassiz, American Journal of Science and Arts, I854, p 354. 
in our admiration of his great achievements. Le Sueur is remembered as the "first to explore the ichthyology of the great American lakes. Laboring with these, and greatest of them all in respect to the extent and range of his accomplishments, is one whose name has been nearly forgotten, and who is oftenest mentioned in the field of his best labors with pity or contempt." 1

It is doubtless true that while, as Professor Agassiz has said, Rafinesque "was a better man than he appeared," and while he was undoubtedly a man of great learning and of greater energy, his work does not deserve a high place in the records of science. And his failure seems due to two things: first, his lack of attention to details, a defect which has vitiated all of his work; and, second, his versatility, which led him to attempt work in every field of learning. As to this, he says himself:

"It is a positive fact that in knowledge I have been a botanist, naturalist, geologist, geographer, historian, poet, philosopher, philologist, economist, philanthropist. By profession a traveller, merchant, manufacturer, brewer, collector, improver, teacher, surveyor, draughtsman, architect, engineer, pulmist, author, editor, bookseller, librarian, secretary, and I hardly know what I may not become as yet, since, whenever I apply myself to anything which I like, I never fail to succeed, if depending on myself alone, unless impeded or prevented by the lack of means, or the hostility of the foes of mankind."

But a traveller Rafinesque chiefly considered himself; and to him all his pursuits, scientific, linguistic, historical, were but episodes in a life of 1 American Naturalist, 1876. 
travel. Two lines of doggerel French were his motto :-

\author{
"Un voyageur dès le berceau, \\ Je le serai jusqu'au tombeau." \\ "A traveller from the cradle, \\ I'm a traveller to the tomb."
}

Long before the invention of railroads and steamboats he had travelled over most of southern Europe and eastern North America. Without money except as he earned it, he had gathered shells and plants and fishes on every shore from the Hellespont to the Wabash.

Concerning one element of Rafinesque's character I am able to find no record. If he ever loved any man or woman, except as a possible patron and therefore aid to his schemes of travel, he himself gives no record of it. He speaks kindly of Audubon; but Audubon had furnished him with specimens and paintings of flowers and fishes. He speaks generously of Clifford, at Lexington; but Clifford had given him an asylum when he was turned out of Transylvania University. No woman is mentioned in his Autobiography except his mother and sister, and these but briefly. His own travels, discoveries, and publications filled his whole mind and soul.

Rafinesque died in Philadelphia, in I840, at the age of fifty-six. He had been living obscurely in miserable lodgings; for his dried plants, and his books published at his own expense, brought him but a scanty income. His scientific reputation had not reached his fellow-lodgers, and his landlord thought him "a crazy herb-doctor." He died 
alone, and left no salable assets; and his landlord refused to allow his friends - such friends as he had - to enter the house to give him a decent burial. He wished to make good the unpaid rent by selling the body to a medical college; but at night, so the story goes, a physician who had studied botany with Rafinesque got a few friends together, and broke into the garret and carried away the body, which they buried in a little churchyard outside the city limits, now obliterated by the growth of Philadelphia.

American naturalists have greater honor now than forty years ago: Rafinesque died unnoticed, and was buried only by stealth. A whole nation wept for Agassiz. But a difference was in the men as well as in the times. Both were great naturalists and learned men. Both had left high reputations in Europe to cast their lot with America. Agassiz's great heart went out toward every one with whom he came in contact; but Rafinesque loved no man or woman, and died, as he had lived, alone. If some one who loved him had followed him to the last, it might have been with Rafinesque as with Albrecht Dürer: " Emigravit' is the inscription on the headstone where he lies." But there was no one ; and there is neither headstone nor inscription, and we know not even the place where he rests after his long journey.

Rafinesque's last recorded words were these: "Time renders justice to all alike." And to the justice of Time we may leave him. 


\section{A CUBAN FISHERMAN.}

"A $\mathrm{H}$, but you must see Don Felipe, - he knows A all about fishes!" is the first advice which the naturalist receives when he begins to make collections of fishes in the markets of Havana. The writer once had occasion to make such a collection, and he soon found that among fishermen and fishmongers the phrase "amigo de Don Felipe" was ever a passport to honest dealing and to a real desire to aid him in his work. For every fisherman in Havana knows Don Felipe, and looks upon him as a personal friend. Each one regards the fame which Don Felipe's studies of the fishes is vaguely understood to have brought him in that little-known world outside of Havana as in some sort reflected on himself. The writer was told, by a dealer in the Pescadería Grande, that for twenty years Don Felipe Poey was there in the markets every day, when at noon the fishes came in from the boats, and that he knew more about the fishes of Cuba than even the fishermen themselves. And now that Don Felipe no longer visits the markets, he is not forgotten there, and many a rare specimen still finds its way from the Pescadería to Don Felipe's study in the Calle San Nicolas. 
Felipe Poey y Aloy was born in Havana, May.26, I 799. His father was French, his mother Spanish; but Poey early renounced his French citizenship for that of Cuba. His education was received in Havana, and after studying law he became, in I 823, an advocate in that city. But his tastes lay in the direction of natural history, and for this he gradually abandoned his practice as a lawyer. Very early he had made discoveries of mollusks, insects, and especially of fishes, which were new to science. In I 825 he was married to Maria de Jésus Aguirre, a very intelligent lady who is still the companion of his studies. In I 826 he sailed for Paris, taking with him eighty-five drawings of Cuban fishes and a collection of thirty-five species, preserved in a barrel of brandy. These drawings and specimens he placed at the service of Cuvier and Valenciennes, who were then beginning the publication of their work on the "Natural History of the Fishes." The notes and drawings of Poey proved of much service to the great ichthyologists. A few new species were based on them, and Poey had the satisfaction of finding his own name and observations cited by Cuvier and Valenciennes even more frequently than those of his famous predecessor, Don Antonio Parra, ${ }^{1}$ who had published, in 1787 , the first account of the Fishes of Cuba. ${ }^{2}$ A set of duplicates of these notes and drawings is still retained by Professor Poey. While

1 Y tuve el honor de ser citado por él (Cuvier) y por su colaborador Valenciennes, más frecuentemente que D. Antonio Parra. - PoEY.

2 Diferentes Piezas de Historia Natural de la Isla de Cuba. 
in Paris, Poey was one of the original members who founded the Entomological Society of France.

On returning to Havana in 1833 , Poey gave himself still more fully to the study of natural history, and greater practice gave to his drawings and notes more exactness and value. With the appearance of the successive volumes of the "Histoire Naturelle des Poissons," he attempted to identify the fishes of his market, as well as to study their osteology and general anatomy. Animals other than fishes he also tried to study, but in most groups he found the literature in so scattered and unsatisfactory a condition that he rarely ventured to publish the results of his observations. Among the fishes, however, thanks to the general work of Cuvier and Valenciennes, and later to that of Dr. Günther, he felt comparatively sure of his results, and ventured to name as new those which he could not identify. The land-snails of Cuba, too, Poey and his associate, Dr. Juan Gundlach, were able to identify and describe with certainty, as all the species then known were included in the "Monographium Heliceorum Viventium" of Dr. Ludwig Pfeiffer.

In the year I 842 Poey was appointed to the professorship of Comparative Anatomy and Zoölogy in the Royal University of Havana, which chair he still holds, after forty-five years. The University of Havana occupies an ancient monastery building in the heart of the city. Like most such edifices in Cuba and Spain, it is a low building around a paved court, and its whitewashed, time-stained walls have an air of great antiquity. The univer- 
sity has now some twelve hundred students, the great majority of whom are in those departments which lead toward wealth, or social or political preferment, as law, medicine, and pharmacy. Comparatively few pursue literary or philosophical studies, and still fewer are interested in the biological sciences. In the department of botany there are now but two students, and the number in zoölogy is probably not much greater.

Although Professor Poey is evidently held in very high respect in the university, in which he has long been dean of the faculty of science, I cannot imagine that he ever received much help or sympathy in his scientific work from that quarter, or indeed from any other in Cuba. His friends and countrymen are doubtless glad to be of assistance to so amiable a gentleman as the Señor Don Felipe, but they have very little intelligent sympathy for the claims of science. The university library contains but little which could be of help in Professor Poey's zoölogical studies. He has therefore been compelled to gather a private library of ichthyology. This library has with time become very rich and valuable, many of his co-workers in the study of fishes, notably Dr. Bleeker, having presented him with complete series of their published works. Two of Poey's daughters who still reside with him in Havana have been of much help to him in the preparation of drawings and manuscripts.

The museum of the university occupies two little rooms, - the one devoted chiefly to Cuban minerals ; the other containing mostly mammals, birds, and 
fishes mounted by Poey himself in the earlier days of his professorship. The number of these is not great, nor have many additions been made during the last twenty years. Most of the types of the new species described by Professor Poey have been, after being fully studied by him and represented in life-size drawings, sent to the United States National Museum, to the Museum of Comparative Zoölogy, or to the Museum at Madrid. Duplicates have been rarely retained in Havana, the cost of keeping up a permanent collection being too great. As a result, Professor Poey's work has suffered from lack of means of comparing specimens taken at different times. There is no zoölogical laboratory in Cuba except the private study of Professor Poey; and here, for want of room and for other reasons, drawings have, to a great extent, taken the place of specimens.

The publication of the observations of Professor Poey on the animals of Cuba was begun in $185 \mathrm{I}$, in a series of papers entitled "Memorias sobre la Historia Natural de la Isla de Cuba." These papers were issued at intervals from I 85 I to I 860 , and together form two octavo volumes of about 450 pages each. The first volume contains chiefly descriptions of mollusks and insects. The second volume is devoted mainly to the fishes. As is natural in the exploration of a new field, these volumes are largely occupied with the description of new species. They give evidence of the disadvantages arising from solitary work, without the aid of the association and criticism of others, and without the broader knowledge of the relations of groups which 
comes from the study of more than one fauna. On the other hand, Professor Poey enjoyed the great advantage of having an almost exhaustless supply of material; for there are few ports where fishes are brought in in such quantities, or in such variety, as in the markets of Havana.

It is the fashion in some quarters to decry the work of the describer of new forms. This is unjust as well as absurd. All honest study has its place; and till the pioneer work of exact determination of species is performed, there is little opportunity for fruitful work on the part of the embryologist or the anatomist. It is of little use to record the structure or the development of an animal, while the animal itself is unknown.

The "Memorias" were at once recognized as the most important work on the fishes of Cuba; and as was said long ago by Professor Cope, this work is a sine qua non in the study of the ichthyology of tropical America.

The nomenclature and grouping of the species in the "Conspectus Piscium Cubensium," contained in the "Memorias," was in I862 the subject of a critical paper by Dr. Theodore Gill. ${ }^{1}$ This article, and subsequent ones by the same author, exerted much influence on Poey's work. He was always ready to profit by the suggestions and advice of other writers, especially of those more favorably situated than he in regard to libraries and museums; from Professor Gill's papers he gained clearer

1 "Remarks on the Genera and other Groups of Cuban Fishes," Proceedings of the Academy of Natural Sciences, Philadelphia, I862, pp. 235 et seq. 
views of the relations of forms, and of the connection of the Cuban fauna with that of other regions. On the other hand, he was led to adopt, against his own judgment in many instances, that minute subdivision of genera which has been a fashion in American ichthyology, and which has been in some quarters a reproach to American science.

In 1868 the results of the revision of his classification were embodied in a second catalogue of the Cuban fishes, entitled "Synopsis Piscium Cubensium." This forms the concluding chapter of a series of papers, entitled "Repertorio Físiconatural de la Isla de Cuba," which embody the results of a general scientific survey of the island. Of this survey Professor Poey was director. In 1875 the entire list of species was again revised, and the third and best catalogue of Cuban fishes was published under the title of "Enumeratio Pis- . cium Cubensium." Besides these larger works, many shorter papers by Poey occur in the "Proceedings of the Academy of Natural Sciences" of Philadelphia, the "Annals of the New York Lyceum," and the "Anales de la Sociedad de Historia Natural de Madrid." $\mathrm{He}$ is also the author of a Geography of Cuba, and of a treatise on Mineralogy, used in the Havana schools. A number of poems from his pen have likewise been published, but these I have not seen.

The great work of Poey's life is the still unpublished "Ictiología Cubana." This is to contain a detailed account of each of the fishes of Cuba. It is to be composed, according to a published statement of Poey, which I here translate, - 
"of a thick volume of text, Spanish folio, and of an atlas of ten volumes larger folio (eighteen by thirteen inches). The plates are made with a light indication of the colors, which are described in the text. All are original, drawn from nature by the author. . . . The text contains the scientific name of each species, the common name, the complete synonymy, a description of the colors, distinctive peculiarities, relations of the varieties, comparisons, critical observations, and the history of the fish. It contains, moreover, the characters of classes, sub-classes, orders, families, genera, and species. The total number of plates in the Atlas is $\mathrm{r}, 04 \mathrm{O}$. These show 758 species of Cuban fishes, represented by I,300 individuals in all stages of growth. All except the sharks are drawn of life-size. These 758 species, together with 24 mentioned at the end of the work, make up $7 \delta_{2}$ species of Cuban fishes. Of these, ro5 are doubtful, and therefore are left without specific names. I hold them in suspense till I can receive further data from the study of other specimens. There are, therefore, 677 species well determined, of which more than half have been first made known by me. Not more than a dozen species in the list have not been examined by me. These are inserted on the authority of writers who claim to have received their specimens from Cuba, and who appear to be worthy of confidence. The preparation of the text has cost me an immense amount of time and labor, by the preparatory studies which it has required. In the determination of the species it is rarely that a single one has not occupied me for an entire week. I have wished to make known the certain as certain, and the doubtful as doubtful, so that I shall declare nothing to be new unless it is so in reality."

The manuscripts of this great work are now in duplicatc. Profcssor Pocy retains onc copy; the 
other has been purchased by the Spanish Government for $\$ 4,000$. It is earnestly hoped by Professor Poey and his friends that the Government will soon order its publication; but, unfortunately, there seems to be no certainty of this. The manuscripts and drawings of the "Ictiología Cubana" were placed on exhibition by the Spanish Government in the Exposition of Amsterdam in 1883. In testimonial of their worth, Professor Poey has received from King William III. the decoration of the order of the "Lion Néerlandais." Before this, as the most distinguished of Spanish naturalists, he had received from the King of Spain the title of "Encomendador de la Orden de Isabella la Católica."

Among the manuscripts of Poey is one bearing the title of "Corona Pocyana." This is a list of the species of animals and plants which other naturalists have named for him as "Poeyi" or "Poeyanus," in friendly recognition of the value of his work. This list is a long one, but the kindly tributes which it implies have not been undeserved.

There is no characteristic of Poey's work more striking than its entire lack of prejudice, or, in other words, the teachableness of the man himself. $A$ certain zoölogist was once described to me by $D r$. Kirtland as "a little man who could n't be told anything." His character was in this regard just the reverse of that of Professor Poey. Among all the naturalists of our time, I know of none more willing to learn, whatever the source from which information may come. He has no theories which he is not ready to set aside when a better suggestion 
appears. Unlike some other systematic writers, he exhibits no preference for his own names or subdivisions, but is as ready, if the evidence seems to require it, to smother one of his own species or genera as those of another. His work shows little sign of falling off in quality. The clearness of his judgment and the accuracy of his memory seem unimpaired. It is difficult in conversing with him to realize that he was born in the last century, and that in his earlier studies he was a contemporary of Lamarck, Cuvier, and of Geoffroy Saint-Hilaire. Many men are older at fifty than Poey at eighty-five.

Old age and its accompanying infirmities are now narrowing the circle of Professor's Poey's life. His walks seldom extend themselves beyond the confines of his study and the little courtyard, shaded by tropical trees, into which his door opens. Some two hours each day he still devotes to the study of fishes. He eagerly reads every new work on his favorite science, and is as anxious as ever to obtain the freshest ideas on classification, or the latest points in synonymy. As an evidence of his freedom of mind and lack of prejudice I may cite his acceptance of the various scientific theories and conclusions embraced in the name "Darwinism," and his general acceptance of the philosophy of evolution as developed by Herbert Spencer, an author for whom he has expressed to me a special admiration. This is the more remarkable when we remember that almost his whole life has been passed in Cuba, - a condition where all tendencies of society and of Church are away from such studies and speculations. 
Like most men who have studied Nature for love of her, Poey possesses a deeply religious spirit. Everything to him proclaims the presence of Divinity. "I believe with Lamarck," he has said, "that there is nothing but God in the Universe, and that by the word Nature we ought to understand an order of things... Him whose true name we cannot decipher; who in the burning bush, questioned by Moses, said, 'I am that I am;' who on Mount Sinai called himself Jehovah, and whom in our mortal tongue, with filial tenderness, we call God." 1

Poey is rather above the medium height, heavily built, and in his younger days he possessed unusual physical activity and vigor. ${ }^{2}$ In appcarance he offers a marked contrast to most of his countrymen, the Cubans. His complexion is fair, his hair - now white - was never dark, and his gray eyes suggest the Saxon rather than the Spaniard. As he once said to me, "Comme naturaliste, je ne suis pas espagnol: je suis cosmopolite." His full forehead, strong features, and handsome, smoothshaven face are not misleading evidences of a pure and benevolent life. He has a most happy temperament, and his smile is peculiarly genial and cheery. Simple, direct, unaffected, he is one of the most delightful of men. Of all men whom I have known, none has better than he learned the art of growing old.

1 Memorias de Cuba, vol. ii p. 4r4.

2 Professor Poey died in I89I. 


\section{THE FATE OF ICIODORUM. ${ }^{1}$}

F you look on a good map of France, you will 1 find, a little south of the centre, a small squarish area, painted red, and bearing the name of Puyde-Dôme. Puy-de-Dôme is a strange region, made up of fertile valleys separated from each other by ragged hills which were once volcanoes in Palæozoic times. These volcanoes have long since retired from active life, and are black and dismal now, their faces scored by lava-furrows, like gigantic tearstains dried on their rugged cheeks. In their craters are ponds of black water full of perch and trout as black as the rocks above which they swim. The highest of these hills the people call the Puy-deDôme, - the Cathedral-peak. There is an observatory on the top of it, and all the country that you can see from the mountain-summit makes up the "department" of Puy-de-Dôme.

On the south side of the department, near what one might call the "county line," you will find, if your map is a good one, the little city of Issoire. Issoire is a very old town. The Romans knew it. They found it when they invaded Gaul, I900 years

1 The chief present interest of this essay is perhaps to be found in the fact that nearly all the historical events related in it have taken place since the date of its first publication in the "Popular Science Monthly" in August, 1888. 
ago, and they called it Iciodorum. They found it again in the year 287, when they came up to convert the Gauls to Christianity, - a thing which they had neglected to do upon their first visit. The Romans brought with them a pious monk, Saint Austremoine by name; and the people of Iciodorum captured him, and he was duly roasted in accordance with their heathenish customs. So, as the blood of the martyrs is the seed of the Church, Issoire came in time to be famous as having the largest church and the best parish schools in the whole region of Auvergne.

Issoire has a long, long history, which is duly set forth in Joanne's "Guide-Book." Its story is one of castles and robbers and chivalry, with here and there a fair dame and an ancestral ghost, perhaps, but of this I am not so certain. Once Issoire fell into the hands of the famous knight Pierre Diablenoir, the Duke of Alençon. After plundering all the shops, burning the houses, killing most of the people, and scaring the rest off into the woods, he set up in the public square a large column bearing this simple legend, "Ici fut Issoire!" ("Here was Issoire.") Were it not for this touching forethought, we might be to this day as ignorant of Issoire's location as we are of the site of Troy.

But the years went on, the wars were ended, the rain fell, the birds sang, the grass grew, the people came back, and Issoire arose from its ashes. Today it is as dull and cosy a town as you will find in all France. It has now, according to Joanne, a population of 6,303 souls, and a considerable trade in grain, shoes, millstones, brandy, and vinegar. 
The streets of Issoire are narrow, and the houses are crowded closely together, as if struggling to get as near as possible to the church for protection. The city lies in the fertile valley of the little river Couze, surrounded by grain-lands and meadows. Toward the north a long white highway, shaded by poplars, leads out across the meadows and hills toward the larger city of Clermont-Ferrand, the capital of the department of the Puy-de-Dôme. Issoire is enclosed by an old wall, and where the highway enters the town, it passes through a ponderous gate, which is always closed at night, as if to ward off an attack from some other Duke of Alençon.

I strolled out one midsummer afternoon on the road leading to Clermont. When I came to the city gate, I first made the acquaintance of the octroi. A little house stands by the side of the gate; and here two or three gendarmes - old soldiers dressed in red coats with blue facings - watch over the industries of the town. Wheelbarrow loads of turnips, baskets of onions or artichokes, wagon-loads of hay, all these come through the city gate, and each pays its toll into the city treasury. One cent is collected for every five cabbage-heads, or ten onions, or twelve turnips, or eight apples, or three bunches of artichokes, and other things pay in proportion. This payment of money is called the octroi. The process of its collection interested me so that I gave up all idea of a tramp across the fields, sat down on an empty nail-keg, and devoted myself to the study of the octroi.

The octroi is an instrument to advance the pros- 
perity of a town by preventing the people from sending their money away. It is a well-kpown fact that individuals become poor simply because they spend their money. So with cities. What is true of the individual is true of the community, itself but an aggregation of individuals. Nations, as well as individuals, grow rich by doing their own work. Commerce, as is well known, is a great drain on the resources of a town as of a nation. Now, if in some way we can keep the money of a town within its limits, the town cannot fail to grow rich. As Benjamin Franklin once observed, "A penny saved is twopence earned." The great problem in municipal economics is this: How shall we keep the town's money from going out of it? How shall we best discourage buying, - especially the buying of articles from dealers outside?

To meet this problem, the wisdom of the fathers devised the octroi.

In view of the prospective introduction of the octroi into America (and I trust that I am violating no confidence in saying that this is the real object of the present visit to Europe on the part of one of America's foremost statesmen), it is worth while to examine carefully its nature and advantages.

Years ago, before the octroi came to Issoire, the city was noted chiefly for the barter of farm products. The farmers used to bring in grains, hides, cheese, and other produce, which they would exchange for clothing, sugar, coffee, tobacco, and the various necessaries of existence. The merchants used to load the grain into wagons which were driven across the country to the city of Clermont. 
Here the grain was exchanged for clothing, food, and all manner of necessaries and luxuries which were made in Clermont, or which had been brought thither from the great city of Lyons. There were long processions of these wagons, and all through the autumn and winter they went in and out. And the Issoire people were very proud of them; for neither coming nor going were they empty, and the teamsters of Issoire were the most skilful in the whole basin of the Loire.

But the mayor of the city and other thoughtful people saw cause for shame rather than for pride in the condition of Issoire's industries. It was ruinous thus steadily to carry away the wealth of the land and to exchange it for perishable articles. When a wagon-load of boots, for example, had been all worn out, then the boots were gone. The money that had been paid for them was gone, and so far as Issoire was concerned, it was as much lost as if money and boots had been sunk in the bottom of the sea. The money that was paid out, I say. Not so with the money that was paid in. If those boots had been bought in Issoire, the money that they cost would still be in town, still be in circulation, and would go from one to another in the way that money is meant to go. This drain must be stopped, and the octroi could stop it. So it was enacted by the Common Council of Issoire that "whosoever brings a pair of new boots into Issoire shall be compelled to pay ten francs," which was the cost of a pair of boots at Clermont. The purpose of this order was not to raise money, but to have boots made at Issoire, that the wearing out of 
these necessary articles should not wear out, at the same time, the wealth of the town.

" People will have boots," the mayor said; " they cannot afford to bring them in from Clermont, and so they will make them at Issoire, and all the bootmoney will remain at home. It is as though, so far as the city is concerned, Issoire gets her boots for nothing. To be sure, Clermont has good waterpower, and her nearness to the mountains makes the price of hides and tan-bark lower, but this has nothing to do with the question. Natural advantages amount to nothing when artificial advantages can be given by a mere stroke of the pen. The laws of political economy are not of universal application. Depend upon the octroi to make all things equal."

A new boot-factory was now built at Issoire, and boots were offered for sale at twenty francs a pair. The cost of boots at Clermont was ten francs, and the octroi charges at the city gate amounted to ten francs more. Buying at twenty francs would save the purchaser a trip to Clermont and back, and, as trade is apt to flow in the direction of least resistance, after a little the Issoire boot industry became fairly established. There was some grumbling at high prices. Some of the laboring classes went barefooted, while the doctor and the schoolmaster put their boys and girls into wooden shoes, or sabots, such as peasant children wear. But the mayor and the Common Council took shares in the new factory, and, being members of the company, they got their boots at the old rate, besides having a part in the large dividends which the business soon began to 
yield. Employment was given to more workmen, who came over from Clermont; the hum of machinery took the place of the creaking of farm-wagons, the rich began to grow richer, the poor went barefooted, and the people of moderate means felt able to run into debt because they lived in a progressive town. The wives of the members of the Common Council bought diamonds, and the members presented the mayor with a gold-headed cane. Soon other boot-factories were started, and still others, though, strangely enough, the more boots were produced, the more barefooted children were seen in the streets.

By and by the tanners decided that they too must ask for help from the octroi. It was as bad, they said, for the factories to send to Clermont for leather as for the merchants to send for boots. In either case the money went out of the town, and was gone forever. So the octroi was levied on leather as well as on boots. Then the guild of butchers put in similar claims. To buy raw hides of the herdsmen out on the Puy-de-Dôme was a part of the same suicidal policy. The octroi was therefore assessed on all imported skins. The butchers established their own stock-yards within the city walls, and were saved from the pauper competition of the mountain cattle. Then the mountain herdsmen drove the cattle on to Clermont, and Issoire was left in peace.

But some of the boot-makers complained that this policy was injuring their business by greatly raising the price of hides, whether produced in Issoire or at Clermont. So the mayor sent a letter 
to the Issoire "Gazette," a long letter which the schoolmaster had helped him to compose, and in which he showed conclusively that the purpose of the octroi was to make things, not dearer, but cheaper. Said he: "The ultimate result of the octroi is always in the end to reduce prices. The sole purpose of the octroi on hides, for example, is to educate our people in the art, so to speak, of raising hides. By this education, they may, by superior intelligence, experience in the business, and the acquirement of knowledge on the subject, be enabled to produce cowhides in such abundance, by new and improved methods, that they may sell them much cheaper than they do now, sell more of them, and yet realize a larger profit on each hide than they can do at present. If there is a fair prospect that this can be accomplished, who shall say that it is not a part of wise statesmanship to attempt this result? Cattle-raising is now carried on in the most primitive way, by driving the cattle about as though they were wild beasts from place to place on remote and uninhabited hills. The octroi will tend to encourage each householder in Issoire to keep his own cow, produce his own leather, thus diversifying his business and giving him some new product to sell every year, some new demand for labor."

And the thoughtful men of Issoire, the leaders of public opinion, saw the force of this argument, and they were satisfied to submit to temporary inconvenience for the sake of the industrial education of the people.

But the boot-trade was already growing slack. 
The market had supplied boots for all, but the people perversely refused to take them. The shop-windows were full of boots, temptingly displayed in rows of assorted sizes; nevertheless, every person in Issoire, except those engaged in boot-making, seemed bent on wearing his last year's boots rather than to pay twenty francs for a new pair. The high price of leather and hides since the exclusion of the mountain cattle began to reduce the profits in boot-making, and so some of the factories threw a poorer article on the market, without, however, any corresponding reduction in price. And people found that it was cheaper to go to Clermont again for boots, notwithstanding the payment of the octroi. Accordingly, the old wagons were sent out once in a while, by people who had more cupidity than patriotism. And a little coterie of aristocrats who sneered at the mayor as a demagogue, and at the octroi as a " relic of the middle ages," used to wear Clermontmade boots and to ape Clermont fashions. But all good citizens discouraged this, and the maintenance of the "Issoire idea" became one of their articles of faith, next to those in the catechism.

But Clermont-made boots often came in on the sly - no one knew how - to the dismay of the local dealers. The Common Council saw that this would not do, and that the single old soldier who guarded each of the city gates could not meet all the requirements of the octroi. So at each gate were placed a dozen gendarmes, in red woollen uniforms, with black caps fastened on by a leather band which went around the lower lip. And the 
gendarmes searched every cart and every ashbarrel that went in or out. They watched every rat-hole in the wall to see if haply, by day or by night, boots should come into Issoire without the chalk-mark of the octroi. Occasionally some poor wretch was taken in the act of throwing boots over the wall, and made to pay the penalty of his crime. But sometimes even the gendarmes themselves, the guardians of the prosperity of the community, were seen walking about in Clermont-made boots, which they had obtained by a process known as " addition, division, and silence." The mayor noticed this one day, but the gendarmes had just presented him with a gold-headed cane. They were very much devoted to the Issoire idea - it was just before election - and on the whole he thought it best to say nothing about it.

The problem now before the mayor and the Common Council was this: How shall we put life into the boot-trade? The stock was large, its quality was excellent, and yet for days at a time the boot-shops would not see a customer. Something must be done. At last, an ordinance was passed that every citizen of Issoire must have at least one new pair of Issoire-made boots, which must be worn on Sunday afternoons when the band played in the park, - at which time the gendarmes would go about on a tour of inspection. When Sunday came, half the workingmen stayed at home all day, because they had not the money to meet the requirements of the law.

But a few of the bolder ones went to the mayor and said openly: "If you want us to wear Issoire- 
made boots, you must furnish them for us. You ought to do it anyhow. This city owes us a living, and we came over here from Clermont to get it. We were told that the workingman in Issoire would have the octroi on his side, and would not have to work like a slave to keep soul and body together, as we had to do at Clermont. But it is the same old story here. We do all the work, and somebody else gets all the profits. Now we have to buy and pay for the boots we make ourselves. The cowhide in a pair of boots costs the capitalists but a franc, and we, the boot-makers, pay twenty francs for the boots when we have made them. The other nineteen francs are the product of labor, and ought to belong to us. Our boots should be furnished at a franc a pair."

So they held a mass-meeting in the café of the Lion d'Or, and resolved that the rights of man were not respected in Issoire. They sent a delegation to the mayor, asking that boots for the workingman be furnished at the expense of the town. This would be but justice, and moreover it was the only way to start anew the wheels of industry. Money should not be locked up in the city treasury. It should go from man to man, and this action was sure to set it going.

Then the schoolmaster wrote a long letter to the Issoire "Gazette," and showed very clearly that this claim was on the whole a just one. Nobody understood the argument, but all applauded it because it looked very learned; and, moreover, its conclusions were in harmony with their previous opinions. The schoolmaster showed that, as boots 
were worth twenty francs a pair, and the leather in them cost but one franc, the nineteen francs left were the product of labor, and should rightfully be returned to the laborer. Now, in Clermont, where boots were made by pauper labor, the boots sold for ten francs, and the leather in each pair was worth but fifty centimes. In Clermont, therefore, the rightful share of labor, even if labor had its due, which it never has in this world, was only nine and a half francs; that is, to labor belonged nine and a half francs on each pair of boots in Clermont, and nineteen francs in Issoire. The lot of the laborer was therefore twice as delightful in Issoire as in Clermont, this difference being due to the beneficent influence of the octroi.

And the Common Council, who were friends of labor, decided that hereafter the price of boots should be twenty francs to workingmen, but that nineteen francs of this should be paid as a bounty from the public treasury. But, " always taking out of a meal-bag and never putting in, soon comes to the bottom," as Benjamin Franklin once said, and there have been few shrewder observers of French politics than he. One morning, when the treasurer put his hand into the strong-box to get the nineteen francs to pay for one more pair of boots, he found it empty. There were only a bad franc, a fifty-centime note, and half a dozen copper sous and two-centime pieces; nothing more. He had come to the bottom.

Here was a crisis! The mayor and the Common Council were called together in haste. The workman Jacques, who wanted the boots, was waiting 
outside, a big, burly fellow, with a sledge-hammer fist and an unpleasant look in his eye. The mayor took one glance at him, and saw that he was not to be trifled with. Moreover, this one case was not to end the difficulty. The road from Clermont and the road across the mountains to Aurillac, the chief town of the next department, Cantal, were black with the advancing hosts of workmen coming to share the privileges which Issoire held out to the oppressed of every city. Through the windows of the Hôtel de Ville the mayor could see them coming, and he knew that the demand of each one of them would be "boots." It was not one pair of boots to be paid for, it was a thousand! There were boots enough in Issoire. The factories were never so prosperous, and the money they received from the city was kept in rapid circulation. The grocers got some, the butchers some, a good deal went to the landlady of the Golden Lion, and the wives of the factory-owners and the councilmen bought diamond necklaces and bracelets to match the ear-rings which they had before.

But this could not go on unless the city treasury could meet the demands upon it. In the words-of a celebrated economist, "The mill can never grind again with the water that is past," and, unless new water could be procured, grinding was over at Issoire. The town must have money, or else the factories would be closed, the supply of boots cease, and each citizen of Issoire would have to keep the wolf from the door by his own unaided exertions.

It was a great crisis; but such crises, "God's 
stern winnowers," as the poet calls them, are the making of great men. And this crisis made a great man of the mayor of Issoire, or rather it made a background against which his greatness could be seen. I have forgotten the mayor's name, and I am very sorry for it. It was a French name and wholly unpronounceable to me, something like De Roncevalle or De Rousselieu; but if ever the name of a mayor were

" On Fame's eternal beadroll worthy to be filed,"

it is his, and it is my constant regret that I cannot file it there.

And the mayor said: "All our prosperity is due to the action of the octroi on a single article of necessity, - namely, boots. This is prosperity along a single line only, a one-sided development of our industries, and from this comes our present embarrassment. Put the octroi on everything, and you have prosperity along the whole line. Some of these things we can produce at home, some we cannot. Those that we cannot produce the people will have somehow, and from these you can raise the money to pay for the boots which Issoire recognizes as the just due of the toiling workingman." Here the mayor wiped a tear from his eye, and raised his voice a little, in the hope that perchance some toiling workingman might be listening outside, or taking his needful midday rest at the Golden Lion, next door.

"On the tea, coffee, pepper, brass, tin, diamonds" (here the Common Council heaved a sigh), "and other articles which Issoire cannot 
produce, we will raise the income which the city needs. And the great charm of this tax is that the people will not feel it at all, for it will all be paid by outsiders, by these merchants from Clermont and Lyons who send their goods to our town. They own the goods, they bring them here, they pay the octroi, for we need not buy of them until the goods are safe inside the city gates. By a single stroke in financial policy, we shall keep our factories running, our workingmen contented, and make the merchants in our rival cities pay all our expenses. As for the other articles which we buy in Clermont, we can make them here, if only we can have the octroi to help us. Extend the octroi to everything, and Issoire will become a microcosm, a little world within a world. We shall do everything for ourselves. There is no excuse for buying anything in Clermont so long as there is a foot of land in Issoire on which a factory can be built. We shall have woollen-factories, and powder-factories, and iron-foundries, and distilleries, and cotton-factories, and wine-vaults, and chairfactories, and stone-quarries, and gold-mines, and flouring-mills, and paper-mills, and saw-mills, and wind-mills, and gin-mills, and - "

But here the mayor began to grow a little incoherent. He had been out late the night before, explaining the advantages of the octroi at the club in the Café de la Comédie, and his private secretary pulled his coat in warning that he should bring his speech to a close.

The mayor's recommendation was accepted in part. A few of the Council had been in favor of 
issuing some kind of cheap money, - some sort of brass or paper token, which they could make by machinery whenever the treasury became empty. But to do anything of this sort successfully would require the consent and co-operation of Clermont. And the merchants and bankers of Clermont said that gold was good enough for them. Besides, in France "the burnt child dreads the fire," and the best people were cowardly in the presence of great financial reforms. So, by way of compromise, they agreed to extend the octroi to twenty-seven articles, - mostly articles of food or clothing which had been brought in from Clermont or from the mountains of the Puy-de-Dôme. The workman Jacques was dismissed with a pair of boots, for which the mayor himself paid. Jacques left the council-chamber satisfied, and the crisis was averted.

And now money flowed in again to Issoire. The farmers who brought in onions paid a little, the boy who pulled water-cresses a little, the milkmen a little, the vine-growers a good deal more, but most of all came in from the merchants of Clermont, who in spite of all discouragement still persisted in carrying cheap goods to Issoire.

Prices went up, - a sure index of prosperity. It was easy to pay one's debts, easier still to make new ones; but the great thing was that the money was kept in town. To go from hand to hand, from hand to hand, and then from hand to hand again, as in the endless round of the fairy tale, - that is what money is for. Factories sprang up as if by magic, and down the long white highways multitudes of the crushed and down-trodden of other 
cities were seen tramping along to share the prosperity of Issoire. Five hundred soldiers in red and blue uniforms had taken the place of the dozen gendarmes, the dome of the church was gilded anew, and the poet wrote a sonnet in which Issoire was compared to the island of Calypso, and the mayor to Ulysses.

But the weather was never so pleasant that nobody had the rheumatism. Never was country so happy that the grumblers all kept still. There were some complainers even at Issoire. Those who lived on incomes and endowments said that with the rise of prices it was every day harder to make both ends meet. One wealthy man who wore Clermont-made boots, and had furnished his sons with private tutors, and saddle-horses, and gold watches, now found it almost beyond his means to keep them in ordinary clothing. But he soon removed to Clermont, and others of the same sort went with him. With them, too, went the widows and orphans who lived on endowments, and the old soldiers who had government pensions.

But the mayor said: "Let them go; it is a good riddance. They belong to the non-producing class, a class that hangs like a millstone on the neck of labor."

But, in spite of all adverse influences, many people from Issoire visited Clermont in fine weather for pleasure or for trade. It was pleasant to wander about the larger town, the home of their ancestors, to be a part in the bustle of its streets, and to breathe its metropolitan air. There were better opera-houses there, and picture-galleries, and there 
was a special charm in the shops where prices far below those at Issoire were ostentatiously fixed on elaborately displayed wares. And so-almost before the owner knew it - many an Issoire wagon was loaded down with cheap goods from Clermont. But although the octroi was paid at the city gates, the real purpose of the octroi was evaded. The money, in the first place, was spent outside the city. Worse than this, the octroi, instead of being paid by the agents of the Clermont merchants, as the law intended, - was collected, as the mayor of Issoire now said, "off our own people." For, if the octroi is to be collected in this way, "off our own people," it would be just as easy and a good deal cheaper and fairer to collect the tax in the usual way, in direct proportion to the value of each man's income or capital.

Another ordinance was clearly necessary. The wagon-maker at Issoire had long since gone out of the business. The prices of wood, iron, leather, and paint were such that he could not compete with Clermont manufacturers. So the wagon-shop was closed, and carriages and vehicles of every description were brought over from Clermont. The cost of these vehicles had been a heavy drain upon the resources of Issoire. The octroi alone would not remedy this, for nothing short of absolute prohibition of outside purchase would revive the wagon-trade. So the mayor proposed that by another bold stroke the dying industry should be revived, while at the same time the citizens of Issoire should be prevented from paying the octroi. It was enacted that no citizen of Issoire should 
own any sort of vehicle - wheelbarrow, cart, wagon, barouche, carriage, or droschke - unless said vehicle was made in all its parts at Issoire, and bore the signature of the mayor and the seal of the Common Council. This saved the city many thousands of francs, - for, now that the people no longer drove over to Clermont, the Clermont merchants sent goods to Issoire; and when they entered the gates, the Clermont people paid the charges of the octroi.

When the first Issoire wagon was finished, the maker had put such a high price upon it that no one would buy, and the reviving industry began to faint again. The wagon-maker said that he could n't help it. Unless he could in some way get wood and nails at special prices, his wagons would be out of the reach of all buyers. A few of the Common Council were in favor of releasing the wagon-maker from the octroi on articles used in the manufacture of wagons; but the rest were unwilling to do this, - because to buy these materials outside is another drain on the prosperity of a town. At last they arranged a compromise, by which the city gave an order for a new streetsprinkler and twelve rubbish-carts, to be paid for from the public treasury. They had no need for a new sprinkler then, and five rubbish-carts would have been enough. But a liberal order like this made the wagon-maker contented, and a generous policy was necessary to start anew the wheels of trade, which, in spite of all their care, were frequently becoming clogged.

Once more the treasury was nearly empty. 
The citizens of Issoire, accustomed to having their taxes paid by the people of Clermont and Lyons, would not submit to any form of direct taxation. Had the Common Council said, "We must have so much money; we propose to take it from your pockets by a pro rata assessment," the people would have risen as one man and put the opposition candidates into office. Direct taxation is a confession of barrenness in expedients. Where money is to be raised, it should always be collected from foreigners, if possible. This is a maxim in political science, and all successful financiers from Julius Cæsar down have acted in accordance with it.

The falling off in the Clermont trade, due to the new wagon law, had made a serious reduction of the revenue. And now appeared the wisdom of the mayor's original suggestion. What Issoire needed was prosperity along the whole line. A partial octroi means only partial prosperity. A universal octroi insures prosperity which is unbounded and universal.

And so the schoolmaster took a copy of Littré's "Unabridged Dictionary" and the "Dictionary of the Academy," and from these he drew up a list of three thousand eight hundred and seventy-two articles on which the city government might levy the octroi. And the mayor and the City Council sat up half the night to decide just how much octroi each one of these articles should bear, in order to secure the best results to the community.

The list began:- 
Absinthe . . . . octroi one franc per bottle.

Accoutrements . . . . " five francs per set.

Acids . . . . . " one franc per litre.

Alcohol . . . . . " five francs per litre.

Alligators . . . . . " " five francs each.

Animals (not otherwise specified) " ten centimes per kilogramme. Arnica . . . . . . " " five centimes per kilogramme. Artichokes . . . . “ five centimes each.

And so on, down to zinc and zoöphytes.

The general effect of this law was like that of a refreshing rain upon a thirsty field. Everybody took heart, and general confidence in the future is the chief element in financial prosperity. But the law had some curious results.

The octroi on elephants was so high as to be prohibitory, and the Italian organ-grinder thanked his stars that he and his monkey were well inside the city gates before the law went into effect. The combined tax on quadrumana and musical instruments was more than he could pay. Once within, however, he enjoyed a full monopoly; and this, so the schoolmaster told him, was just what the law originally intended, - for octroi is spelled in Latin " auctoritas," "by authority," an authorized monopoly. The manufacturers of dolls were much encouraged. Christmas was coming on; the children must have dolls; and the pauper dollmakers of Jonas, with whom Saint Nicholas had been in the habit of trading, were by no means able to pay the octroi.

But, on the other hand, the trade in lookingglasses was nearly ruined. The octroi on glass, quicksilver, wood, tin, varnish, and glue, drove the mirror-maker distracted. The people took to 
polishing up tin pans, and to looking into dark windows or down into deep wells, in search for the truth that is said to lie there. Then the law offered some curious anomalies. For instance, a sheep with the wool on went through the city gates for fifteen francs. If the wool was taken off, it was charged a franc per pound, and the sheep went in as mutton, paying five francs. It was, therefore, cheaper to take a sheep to pieces outside of the city gate rather than within.

Again, there was a curious complication in the matter of bootjacks, - a humble article of domestic use, manufactured in the little village of Jonas, just mentioned. If these were sent in as household furniture, each paid a franc, while, as woodenware, the charge was fifty centimes.

With the millstone-trade the results were even more remarkable. One of the chief articles of export from Issoire, in its early days, was the stone used in flouring-mills. In the lower part of the city, close to the river Couze, there is an extensive quarry of a coarse, hard sandstone, most excellent for milling purposes. It had long been a saying with Issoire people, "We send Clermont the wheat, and the stones to grind it." The Issoire millstones were not inferior to those quarried in Cantal, and, the distance from Clermont being much less, the Issoire millstone-cutters had almost a monopoly of the Clermont trade.

In the early days of the octroi, however, the wagons which had formerly brought over manufactured goods in exchange for millstones were obliged to go to Issoire empty. Thus their owners 
had to charge for one trip almost the former price of two. This increased cost of transportation brought down the price of millstones in Issoire, for the competition of the quarries of Cantal made it impossible to raise the price at Clermont. To do that would be to divert the trade of the Clermont mill-owners entirely to Cantal. In such cases, the prices for the whole region must be governed by the price at the centre of trade. The profits of the Issoire quarry were thus materially reduced. The owners talked of reducing the wages of their employés; but this they could not do, for the wages were already at the lowest point at which effective service could be secured. The natural remedy lay in an appeal to the octroi. The Council levied five centimes per kilogramme on all millstones brought into Issoire. Some of the Council thought this levy an absurdity, for not a single millstone had ever been imported. The old proverb as to "carrying coals to Newcastle" was intended to cover just such cases. But the mayor told them to wait and see, and the result showed his far-seeing wisdom. The quarry-owners doubled their home prices, while the octroi preserved them from loss through outside competition. Then followed one of those curious surprises which lend such zest to the study of French economic problems. The price of millstones at the quarry in Issoire was nearly double the price of the same millstones in Clermont, whither they were carried by salesmen from Issoire. After a time Issoire mill-owners began to send to Clermont for millstones, instead of buying them at home. It was cheaper for them 
to buy their home products in another city, to pay carriage both ways, and to pay the octroi at the city gates, than it was to send across the street in Issoire for the same article. Freedom from competition at Issoire enabled the quarry-owners to fix their own prices at home, and thus to broaden the slender margin of profits which came from outside trade. This peculiar condition reached its climax when one of Beltran's wagons from Clermont left Issoire with a load of millstones, while, next day, the same wagon, without unloading, carried the same millstones back to be used in the mills of the Issoire General Company of Flour and Meal! The schoolmaster was ecstatic over the stimulus thus given to several industries at once. It was like killing many birds with one stone. But the Issoire Association for the Home Production of Millstones was not satisfied with Clermont competition, even in this peculiar form, and an increase in the octroi soon put further importations out of the question.

There were also some curious omissions in the list, in spite of its length and complexity. An old woman, Widow Besoin, who lived near the Cantal gate, had five speckled Dominick hens, of which she was very fond. These hens were to her a source of profit as well as pleasure. She came to the mayor with the complaint that her neighbor, Farmer Bois-rouge, who lived just outside the city gate, brought in the eggs of his chickens free, and sold them at prices far below those she was compelled to charge for the eggs of her hens. The Bois-rouge chickens roamed over the whole farm 
and lived on grasshoppers and gleanings, while hers were fed on grain which had passed the octroi. It seems that the schoolmaster, in making up the octroi list, in arranging the $o$ 's had neglected to look for words beginning with oe, and so had omitted the word ouf, which is the French for " egg." So the Council was called together, a rate for cellfs was agreed upon, and Widow Besoin's Dominick hens were free from the pauper competition of the chickens of Farmer Bois-rouge.

But the action of the octroi was on the whole, as I have said, extremely beneficial. It filled the treasury again, and it stimulated a large number of infant industries, which had previously been unable to compete with established industries in surrounding towns, on account of the high prices of raw materials, and especially of labor, at Issoire. It is true that workman Jacques and some of the other laborers complained that these high wages were high in name only. In Clermont men worked for three francs a day; but these three francs would buy twelve yards of calico or ten pounds of sugar, while the five francs received in Issoire would buy but ten yards of calico or eight pounds of sugar. But the schoolmaster wrote another letter to the "Gazette," showing that the question of wages was solved by an estimate of what the laborer saved, not by what he could buy with his wages. "Every workingman," said he, "as statistics show, saves thirty per cent of his wages. In Clermont, therefore, the laborer lays up one franc per day, or three hundred francs per year. In Issoire he lays up one franc fifty per day, or four hundred 
and fifty francs per year, - a difference of one-half in favor of the workman at Issoire as compared with the pauper labor of Clermont."

The workman Jacques read this aloud in the barroom of the Lion d'Or, and pondered over it a good deal, for the logic was irrefutable; and yet after all these years he had not four hundred and fifty francs which he could call his own.

The mayor made a speech to the workingmen, congratulating them on his re-election, and assuring them that "for them and for them alone the octroi was brought to Issoire. It was the pride of Issoire that its workingmen were princes and not paupers. If they paid high prices for articles of necessity, it was only that they might get higher prices in return. You sell more than you buy, and what you sell, the strength of your own right arms, costs you nothing, and, when it is sold, is as much yours as it was before. It is God's bounty to the workingman. If these industries which the octroi has built up around you are left unprotected, you too would be left without defence. In the natural competition of trade, the rich grow richer and the poor poorer. Without the octroi we should behold here as at Clermont the spectacle of the chariot-wheels of Dives throwing dust into the eyes of Lazarus. But here in Issoire Lazarus is, so to speak, already in Abraham's bosom. The workingmen of Issoire have no truer friend than Issoire's mayor, and to cherish their interests is the dream by day and by night of Issoire's Common Council."

But we must return to the boot-trade, on which the octroi was first established. The history of that 
industry is the history of all the others, for in one way or another all experienced the same changes and conditions.

The profits were large at first, and very soon the Issoire Citizens' Foot-wear Manufacturing Association had no longer a monopoly in boots and shoes. The original concern still retained the city contract for supplying boots to the laboring-men, but the others found the general trade no less profitable.

But soon an unexpected decline in boot consumption took place. People perversely wore their old boots, which had long passed the season of presentability. The children went barefooted or shuffled around in sabots. Even worse, many parents bought for their children a new kind of copper-toed shoe, which was made in Clermont, a shoe that could never wear out at all; one of the worst possible things for the shoe-trade in any country!

When it was found that boots and shoes enough to last for five years were for sale in the shops, it was evident that something must be done. The original concern decided to wait. It closed its factory and discharged its workmen. But some of the other firms could not wait. They must have their money back or go into bankruptcy. Shoes began to come down. Every shoe-dealer was alarmed, and a meeting was held in the Café de la Comédie to see what could be done. It was decided to lower the prices and then to maintain them. Boots were rated at fifteen francs per pair, and shoes and slippers in proportion. But one dealer could not keep his promise. He had a very 
large and handsome new shop, and he had spent much money in fitting it up. A gentleman, named Shylock, from whom he had borrowed the money, said that he had lent money for legitimate business, not for speculation; to sell shoes, not to hold them for higher prices. This stock of boots was thus forced on the market, to be sold for what it would bring. And other dealers had to sell for similar prices, or lose all chance of selling at all. And so Issoire was full of notices:-

"Grand Slaughter of Boots and Shoes!" "Boots given away - only Five Francs a PAIR!"

Boots were never so cheap before, in Issoire or anywhere else in France.

The Issoire Citizens' Foot-wear Manufacturing Company took no part in these cheap sales. Its agents were active, however, and they privately bought up a part of the stock of the smaller stores, and sent out several wagon-loads across the country to Clermont, and one down the river to the farmers in the valley of the Loire.

It was an era of cheap boots. Everybody was well shod. The children burned up their wooden shoes, or used them only for coasting in the winter, and there was general satisfaction. The Minister of Public Instruction, who spent a day in Issoire on his way from Marseilles to Paris, had a pair of new boots presented to him, and he showed them at home, as an example of what the octroi could do for a town. "Boots," said he to the Minister of Finance, "are actually cheaper to-day at Issoire 
than they are at Paris or Lyons. So much has the octroi done for my countrymen." And the mayor sent a message of congratulation, reminding the people that his promises had come true. "The octroi has reduced the price of boots, and has demonstrated the truth of the paradox that the quickest road to low prices is to make prices high." The traders who had gone into bankruptcy left Issoire and were speedily forgotten, - except by their creditors, chief of whom was Monsieur Shylock. It did not much matter about them, in any event. Their loss was the community's gain. It was not Issoire's fault that they were dealing on borrowed capital and could not stand the strain of reduced prices.

After the period of congratulation was over, the President of the Issoire Citizens' Foot-wear Manufacturing Association called the heads of a few of the rival houses to his office. They agreed together to ask for an increase in the octroi, in view of the depressed condition of the boot-trade, after which they would, in view of the increase of the octroi, raise the price of boots to twenty-five francs. They formed a new association called the Issoire - Equitable Confidence Society, the object of which was to prevent the Clermont dealers from flooding the city with cheap boots, - a thing which the latter had been steadily on the watch to accomplish. The Equitable Society took special pains to serve Issoire by regulating the price of boots according to the city's real needs. The city had suffered from overproduction. Now, when any firm outside the Equitable Society tried to resume work, 
the price of boots was suddenly lowered, until the competing dealer would be willing to sell out on favorable terms to some of the society's members. There were a few dealers in Issoire who still brought boots over from Clermont. These were made to understand that their course of action was unpatriotic, and that it was displeasing to the members of the Equitable Society. The office of the octroi was visited by several men who accused one of these dealers of having silk stockings concealed in an invoice of boots from Clermont. All the boxes were opened and each boot examined. Then all were thrown in a pile by the side of the street. The owner gathered them up as well as he could; but the street boys helped him, and before he knew it several boys and several pairs of boots were missing together. And so in a hundred ways the Equitable Society discouraged outside and inside competition, until at last the entire boot-trade fell into its hands.

But the rise in the cost of boots had its effect on the workingmen. Clearly the increase in the price of boots was due to the growth of labor, for the price of hides was no greater than it was before, while the value of hides made up into boots was materially higher. If a day's work was worth five francs, before, nine francs was not too much now, when labor was so much more valuable to the capitalist.

The big workman Jacques thought this out, and in the café of the Lion d'Or he advised the workingmen to march in a body to the President of the Confidence Society to demand their rights. They 
did so, with the master-workman Jacques at their head. Their demand was nine francs a day, or no more boots in Issoire. The president had expected this. In fact, he had rather hoped for it; and so he had kept a good stock of boots in reserve for such an emergency.

He spoke very kindly to the deputation, patted Jacques softly on the arm, but, in brief, said that the state of the trade would permit no increase of wages at present. Next day the doors of the factories were closed, and each workman received his pay in full, and his discharge.

For a week the factories were empty and silent. The Confidence Society was not idle, however, for a trusty messenger had been sent at once to the village of Jonas. He offered four francs a day to the Jonas men if they would come over to work in Issoire. Now, Jonas is a queer little town, built all around the brow of an old volcano. I doubt if there is another like it on earth. The top of the hill is made of hard lava, below which is a belt of ashes, very old and packed solid, but as easy to cut as cheese. Long ago the ancient Gauls burrowed into this hill and filled it with their habitations. These appear like gigantic swallows' nests when you look at the hill from below. One of the largest of these houses is used as a church, and its lava walls are rudely frescoed over in imitation of the big church at Issoire. Only very poor people live in Jonas now, - people who cannot pay much rent, and who do not mind the absence of fire in the winter. And the Jonas men were glad to come over to Issoire for four francs a day, to take up the 
work which the pampered laborers of Issoire had refused.

The coming of the Jonas men was a great surprise in Issoire, and gave rise to much hard feeling. The workmen who were idle met them with eggs and cabbages, and some of them even carried bricks. But the gendarmes were on the side of the Confidence Society, and they protected the new men from any serious harm. So the mob followed sulkily in the rear, shouting, "Rats! rats!" It sounded like "Rah, rah!" for this is the way the French peasantry pronounce the word which we call " rats."

Winter was now approaching, and the discharged boot-makers of Issoire found their condition daily more and more unpleasant. They had an association among themselves called the "Chevaliers of Industry." The big Jacques was master-workman, and tliey met in the café of the Lion d'Or to discuss matters of common interest. They had a good deal to say of the power of organized labor, the encroachments of capital, and maintained that the value of all things is due solely to the labor which is put upon it. The so-called raw material, - land, air, water, grass, cowhide, shoe-pegs, - all these are God's bounty to men. No one should arrogate these to himself, and all should be as free as air. All else in value labor has given. Capital, the interloper, has unjustly taken the lion's share, and left a pittance to labor. What capital has thus taken is ours, for we have made it. Then the speaker referred to the snug little capital which the President of the Confidence Society had laid 
away in his strong-box, and which shone out through his plate-glass windows and made itself felt in every smirk of his self-satisfied face. Another speaker said that the thief of labor was the worst of all thieves, and for them to despoil him was but to seek restoration of stolen goods. And the schoolmaster said that he who takes for his own the value labor has given is worse than he who robs upon the public highway, - for he adds hypocrisy to theft.

Some of them counselled an immediate attack upon the managers of the Confidence Society, but the voice of master-workman Jacques was for some compronise which would restore thein to employment. There had been a considerable fund collected by the Chevaliers of Industry in the way of dues and assessments. This fund he had distributed among the unemployed laborers, freely at first, but of late more sparingly. There were many who hoped to live through the winter on this fund, and these spoke in no pleasant terms of the masterworkman's stinginess. The fund was nearly gone, and Jacques well knew that if work was not soon resumed, the order of Chevaliers of Industry would come to a sudden end. Organized labor without cash or credit is very soon disorganized.

A few heeded his words of counsel and followed his lead to their homes. But the bolder spirits stiffened their resolve with the red wines for which the café of the Lion d'Or is so justly famous, and started for the residence of the President of the Confidence Society. They roused him from his bed, killed one of the Jonas men whom they found 
asleep at his door, insisted on an immediate division of his personal property, - which he was only too willing to grant, - and next morning they found themselves in jail, charged with robbery and murder.

There was again excitement at Issoire. The workingmen held mass-meetings at the Lion d'Or, and passed resolutions of sympathy and defiance. The wives and daughters of the members of the Common Council sent bouquets and baskets of fruit to the prisoners, and the mayor said that he loved them as though they were his own sons. But the law in France is in higher hands than those of the municipality. It is swift and sure. The prisoners were taken to the capital city, Clermont, to be tried. The sympathies of the judge were on the side of capital, and he paid little attention to the plea of organized labor. "If your theory is . true," said the judge, "you have no sort of claim on the boots you have demanded from the President of the Equitable Confidence Society. All this labor you talk of is simply the moving of things back and forth. How can this confer value? The real work is done by the cow; and the herdsmen on the mountains, who are her heirs and assigns, are the only persons who have a natural lien on the boots which are made from her hide when she is dead. This claim the herdsmen have assigned to capital, and to capital, therefore, all the boots belong."

It is hard to fight against monopolies. The men were condemned. The red flag was raised in the Golden Lion. A good deal was said, but nothing 
further was done, by organized labor toward taking possession of its own.

A new election was at hand, and the mayor's party issued a call to the workingmen to rally to his support.

"All who believe in the grandeur and splendor of France, that honesty is the best policy, that the tricolor should ever wave victoriously over the most glorious land the sun shines on, and that the Issoire idea of a perpetual octroi is the best security for the defence and development of home interests and the elevation of home labor; all who would reduce city taxes and prevent the accumulation of money not needed for city uses, by the perpetuation and extension of the octroi; those who are opposed to all schemes tending to dethrone this policy and to reduce Issoire's laborers to the level of the underpaid and oppressed workers of Clermont and Jonas, - are called to join in the re-election of Mayor de Roncevalle and of his supporters in the Common Council."

The mayor spoke from the steps of the Hôtel de Ville in defence of the octroi, on the success of which agency he justly based his claim for re-election.

He showed how the octroi had changed Issoire from a dull and peaceful agricultural village with few industries, and those only the ones for which the town possessed special advantages, into a microcosm in which a little of everything was made and sold. Issoire was no longer a town where nothing happened, and in which the procession of grain-wagons, the same yesterday, to-day, and 
to-morrow, wearied the eye and the ear with their ceaseless monotony. It was a city in which the clashing of interests and the fluctuation of prices made every one anxious for the morrow's sun to rise that he might see what would happen next. He spoke of the promising infant, the industry of boot-making, which had always stood in the forefront of Issoire's development. He touched lightly on the late labor difficulties, as a mere incident in the city's progress, "a spark struck out from the clashing of great interests as from flint and steel." "Different directions may produce such," said he, unconsciously quoting from an earlier economist; "nay, different velocities in the same direction." Then he spoke of the value of the octroi to the workingman and of the charmed life he leads at Issoire. $\mathrm{He}$ repeated all the arguments drawn from the prices of boots and the prices of labor which the schoolmaster had written out for him, and everything went on beautifully till near the close, when the master-workman Jacques rose to ask a question.

"How is it," said he, "if the lot of the workingman is so pleasant in Issoire, that there is not a single workingman from Issoire in one of the factories in this city? How is it that the mills are full of paupers and 'rats' from Clermont and Jonas? How is it that the census shows that Issoire is actually poorer to-day than she was ten years ago, that her pauper roll is ten times as large, and the only citizens who have grown rich are the city officers and the members of Issoire's iniquitous Equitable Confidence Societies? If the 
octroi is to benefit the laborers of Issoire, why don't you put it on the outside fellows who swarm in Issoire, and not on the Issoire laborers' food and clothing? It seems to me, sir, that when a city begins to fix things to help one set of men and then another, rather than to consider the common good of all, it is on dangerous ground. Once started on this sort of thing, everybody clamors for his share. Every man too lazy to work, and every man whose business does not pay, seems to think that the rest of the town owe him a living."

Warming up with the subject, he continued:

"Take this millstone business of yours, for example. It is all folly to talk of the wealth in your stone-quarries, if you have to hire their owners to work them. If we can buy millstones in Clermont for less than it costs to cut them in Issoire, it is money in our pockets to leave them in the ground. If any line of business needs to be constantly propped up, and cannot live except at the expense of its neighbors, it is no industry at all. It is a beggary. And this octroi of yours has made a beggar or a brigand of every industry in Issoire!"

But the mayor waved his hand and smiled, and said that some men were never satisfied. They would grumble about the golden pavements of the New Jerusalem, if they could not turn them into legal tender. Then he referred to a conspiracy among men suborned by Clermont gold, to flood the streets of Issoire with cheap bread and meat and potatoes and clothing. He asked all who wanted to be slaves to Clermont to rise and be counted. He showed that, of all people on earth, the people 
of France were the happiest; of all people in France, those of Issoire were most favored; and of those in Issoire, the best of all were the workingmen, the especial guardians of the Issoire idea.

Meanwhile the extension of the octroi to three thousand eight hundred and seventy-two articles had greatly increased the wealth of the city, and the city treasurer's strong-box was so full that he had to make a second one, and to hire three trusty Clermont men to watch it day and night, and then three men from Jonas to watch the first three. What should be done with the money to keep it in circulation? For if it remained locked up, the wheels of industry would soon begin to creak, and creaking is a sign that wheels need oiling.

The mayor had proposed to divide it among the several Equitable Confidence Societies, in order to encourage industry, and thus enable these com-. panies to raise still higher the high wages of the men from Jonas, who were now the only laborers employed in Issoire. But this was objected to in several quarters, especially by the followers of the workman Jacques, who did not like to trust the Equitable Societies to make such a division.

The schoolmaster wanted it divided among the school-children pro rata, in proportion to their raggedness. This was favored by almost every one, because it would benefit the laboring-man and help on the clothing-trade; but the politicians objected to giving money to the poor, because such giving tends simply to enervate. The very fact that a man is poor shows that he is not fitted to take care of money. Some wanted the city 
wall built up so high that no one could see out of the town, and then to have the top so beset with broken bottles that no one could climb over. A few of the extreme devotees of the Issoire idea wanted the surplus devoted to destroying the roads to Clermont, that all danger from the flood of cheap goods with which that city stood always ready to overwhelm Issoire would be removed forever. One of the Council even wished to use it for the permanent closing of all the city gates; for, as he said, "if we are good citizens we will have nothing to do with abroad."

But the private secretary of the mayor remarked that altogether too much had been said of this matter of surplus revenue. "It is a good deal easier," he remarked sagely, "to manage a surplus than a deficit." Then the mayor said: "It is much better to have too much money than too little. That is what constitutes prosperity. I would n't mind having a little surplus myself." Then the Council laughed, and each one thought of what he could do with his share of the surplus, while they discussed some plans which looked toward an equitable distribution of it in places where it would do the most good.

The workman Jacques, who was now a member of the Council, and who had been selected as the opposition candidate for mayor, rose and said: "This octroi stuff is all nonsense. It is a tax to make things higher, and it comes out of our pockets. That is why we are so poor. The mayor says that it is collected from the Clermont merchants. The mayor lies. What does a Cler- 
mont merchant care whether we pay him ten francs for a pair of boots outside the city gates, or twenty francs inside, after he has paid ten francs toll? It is all the same to him. He loses nothing either way, except that our ridiculous laws have lost him a good customer for his woollen goods, and we have lost a good customer for our wines and wheat. If I can save ten francs by buying my boots at Clermont, have I not a right to save it, and whose business is it if I do? The octroi is putting into the city treasury every year fifty thousand francs more than the city has any honest use for, and the whole town will go into bankruptcy if this goes on for three years more. There is n't money enough in the city to keep up this surplus. The money cannot get out of the treasury unless some one steals it out and puts it into circulation; and, if I understand you, gentlemen, this is just what you propose to do."

This speech was the sensation of the day. It was spoken with a blunt earnestness such as wellmeaning but ignorant men are often found to possess. Its sophistries were not at first apparent, for the very reason that the speaker himself did not know them to be sophistries.

It was printed next morning in the Issoire "Étoile," and it made many converts among those who were unable to expose its errors. The landlord of the Hôtel de la Poste indorsed it, because the patronage of that excellent hostelry had greatly declined since the cessation of the barter with Clermont. Some of the manufacturers favored it, for they were looking for wider outlets for their 
trade, as the market of Issoire was soon glutted, and the octroi increased the cost of manufacture even more than it raised the price of the finished goods. The politicians said that Jacques' words might be true enough in theory, but talk like that would ruin any man's chances in a popular election. Jacques should have remembered that he was a candidate.

The parish priest, who seldom meddled with politics, declared that the address was timely and patriotic, and that the real friend of the laboringman was the man who gave him justice instead of patronage. What he needs is a free field and fair play. Those who coddle the working-man mean sooner or later to pick his pockets. He further said that, in his opinion, the mayor and Council were wrong in their theories of wealth. Their fundamental error was this, - that they were trying to make the people of this city grow rich off each other. The mayor had said that the blessings of the octroi come to certain classes, but they do not stop there. They diffuse themselves like water, and their beneficent influence is felt on every hand. But these benefits come to the rich first, and from the top they spread down very slowly. But the evil influences of the octroi diffuse themselves in the same way. The only difference is that they begin at the bottom with the workingman, and are nearly exhausted when they reach the top. The priest even marched in a procession which went through the streets, carrying banners inscribed "Vive Jacques, the Master-Workman!" “ À bas l'Octroi!" "Away with Useless Taxes! " 
For he was an unpractical man, easily swayed by theories rather than by emotions.

But the reaction soon came, as it always comes in the politics of France. That it came so early was due to the Clermont newspapers. They published Jacques's speech in full, with words of great approbation.

In the Clermont "Libéral" were the head-lines: "Long live Mayor Jacques!" “Down with the Demagogues!" “Issoire coming to her senses!" "The Working-men repudiate the Octroi!" "Good Prospects for the Clermont Trade!"

It was on the very eve of the election that the Clermont papers were received in Issoire. It was enough. What sophistry had seduced, patriotism reclaimed. The mayor said that if Jacques was elected, the octroi would be removed at once, every man in Issoire would be ruined, and the city, bound hand and foot, would be delivered over to Clermont. Ten wagon-loads of goods would be sent in the place of one, and not all the money in the whole city would suffice to pay for them. Then he read from the Clermont "Libéral" an editorial in which Jacques was compared to Arnold Winkelried and to Charles Martel and to Saint Austremoine, the first hero and martyr of Issoire. The effect was tremendous. Every word from Clermont in praise of Jacques was, as the mayor said, " one more nail in his coffin."

The election-day came at last - as such days always come. It was a bright Sabbath afternoon in early August, for in France elections are always held on Sunday afternoons. The birds sang in 
the poplar-trees, the wheat-fields looked yellow through the city gates, the poppies along the hedgerows stood out in scarlet contrast, the Café du Lion d'Or was covered with flags and with red ribbons in honor of Jacques, while the Café de la Comédie was similarly draped in blue in honor of his rival. The people were out in their best clothes and Issoire-made boots, and the candidates were among them, - all smiles and attention, though I thought that a. slightly misanthropic expression lurked about the big workman's mouth.

The bands played, and rival processions moved about in the street. The longest of these carried banners inscribed "Vive l'Octroi! À bas Clermont! Le Surplus toujours! De Roncevalle forever!" Everybody seemed falling into line; and so I followed, keeping step with the music.

All at once I heard a fearful, blood-curdling scream. The procession swiftly dissolved, the music ceased, the banners vanished. I rubbed my eyes and looked about me. I was sitting on an inverted nail-keg at the Clermont gate just outside the city of Issoire. The old gendarme who guarded the gate was slowly drawing a dripping sword out of a large bundle of oats, in which he had thrust it while performing his duty as inspector. Within the oats was great excitement. The contraband pig concealed inside was lustily kicking and filling the air with his frantic screams.

And thus I knew that the city had been saved, for the octroi was still going on.

And it is going on yet. 


\section{THE STORY OF A STONE.}

NCE on a time, a great many years ago, so many many years that one grows very tired in trying to think how long ago it was; in those old days when the great Northwest consisted of a few ragged and treeless hills, full of copper and quartz, bordered by a dreary waste of sandflats, over which the Gulf of Mexico rolled its warm and turbid waters as far north as Escanaba and Eau Claire; in the days when Marquette Harbor opened out towards Baffin's Bay, and the Northern Ocean washed the crest of Mount Washington and wrote its name upon the Pictured Rocks; when the tide of the Pacific, hemmed in by no snow-capped Sierras, came rushing through the Golden Gate between the Ozarks and the north peninsula of Michigan, and swept over Plymouth Rock, and surged up against Bunker $\mathrm{Hill}$; in the days when it would have been fun to study geography, for there were no capitals, nor any products, and all the towns were seaports; - in fact, an immensely long time ago there lived somewhere in the northeastern part of the State of Wisconsin, not far from the city of Oconto, a little jelly-fish. It was a curious little fellow, about the shape of half an apple, and the size of a pin's head; and it floated around in the water, and ate little 
things, and opened and shut its umbrella pretty much as the jelly-fishes do now on a sunny day off Nahant Beach when the tide is coming in. It had a great many little feelers that hung down all around like so many little snakes; so it was named Medusa, after a queer woman who lived a long while ago, when all sorts of stories were true. She wore snakes instead of hair, and used to turn people into stone images if they dared to make faces at her. So this little Medusa floated around, and opened and shut her umbrella for a good while, a month or two, perhaps, we don't know how long. Then one morning, down among the sea-weeds, she laid a whole lot of tiny eggs, transparent as crabapple jelly, and smaller than the dew-drop on the end of a pine leaf. That was the last thing she did; so she died, and our story henceforth concerns only one of those little eggs.

One day the sun shone down into the water,the same sun that shines over the Oconto saw-mills now, - and touched these eggs with life; and a little fellow whom we will call Favosites, because that was his name, woke up inside of the egg, and came out into the world. He was only a little piece of floating jelly, shaped like a cartridge pointed at both ends, or like a grain of barley, although very much smaller. He had a great number of little paddles on his sides. These kept flapping all the time, so that he was constantly in motion. And at night all these little paddles shone with a rich green light, to show him the way through the water. It would have done you good to see them some night when all the little fellows had their 
lamps burning at once, and every wave as it rose and fell was all aglow with Nature's fireworks, which do not burn the fingers, and leave no smell of sulphur.

So the little Favosites kept scudding along in the water, dodging from one side to the other to avoid the ugly creatures that tried to eat him. There were crabs and clams of a fashion neither you nor I shall ever see alive. There were huge animals with great eyes, savage jaws like the beak of a snapping turtle and surrounded by long feelers. They sat in the end of a long round shell, shaped like a length of stove-pipe, and glowered like an owl in a hollow log; and there were smaller ones that looked like lobsters in a dinner-horn. But none of these caught the little fellow, else I should not have had this story to tell.

At last, having paddled about long enough, Favosites thought of settling in life. So he looked around till he found a flat bit of shell that just suited him. Then he sat down upon it and grew fast, like old Holger Danske in the Danish myth, or Frederic Barbarossa in the German one. He did not go to sleep, however, but proceeded to make himself a home. He had no head, but bctween his shoulders he made an opening which would serve him for mouth and stomach. Then he put a whole row of feelers out, and commenced catching little worms and floating eggs and bits of jelly and bits of lime, - everything he could get, and cramming them into his mouth. He had a great many curious ways, but the funniest of them all was what he did with the bits of lime. He kept 
taking them in, and tried to wall himself up inside with them, as a person would "stone a well," or as though a man should swallow pebbles, and stow them away in his feet and all around under the skin, till he had filled himself all full with them, as the man filled Jim Smiley's frog.

Little Favosites became lonesome all alone in the bottom of that old ocean among so many outlandish neighbors. So one night when he was fast asleep, and dreaming as only a coral animal can dream, there sprouted out from his side, somewhere near where his sixth rib might have been if he had had any ribs, another little Favosites; and this one very soon began to eat worms and to wall himself up as if for dear life. Then from these two another and another little bud came out, and other little Favosites were formed. They all kept growing up higher and cramming themselves fuller and fuller of stone, till at last there were so many and they were so crowded together that there was not room for them to grow round, and so they had to become six-sided like the cells of a honeycomb. Once in a while some one in the company would feel jealous because the others got more of the worms, or would feel uneasy at sitting still so long and swallowing lime. Such a one would secede from the little union without even saying "good-by," and would put on the airs of the grandmother Medusa, and would sail around in the water, opening and shutting its umbrella, at last laying more eggs, which for all we know may have hatched out into more Favosites. 
So the old Favosites died, or ran away, or were walled up by the younger ones, and new ones filled their places, and the colony thrived for a long while, until it had accumulated a large stock of lime.

But one day there came a freshet in the Menomonee River, or in some other river, and piles of dirt and sand and mud were brought down, and all the little Favosites' mouths were filled with it. This they did not like, and so they died; but we know that the rock-house they were building was not spoiled, for we have it here. But it was tumbled about a good deal in the dirt, and the rolling pebbles knocked the corners off, and the mud worked into the cracks, and its beautiful color was destroyed. There it lay in the mud for ages, till the earth gave a great long heave that raised Wisconsin out of the ocean, and the mud around our little Favosites packed and dried into hard rock and closed it in. So it became part of the dry land, and lay embedded in the rocks for centuries and centuries, while the old-fashioned ferns grew above it, and whispered to it strange stories of what was going on above ground in the land where things were living.

Then the time of the first fishes came, and the other animals looked in wonder at them, as the Indians looked on Columbus. Some of them were like the little gar-pike of our river here, only much larger, - big as a stove-pipe, and with a crust as hard as a turtle's. Then there were sharks, of strange forms, and some of them had teeth like bowie-knives, with tempers to match. And the 
time of the old fishes came and went, and many more times came and went, but still Favosites lay in the ground at Oconto.

Then came the long, hot, wet summer, when the mists hung over the earth so thick that you might have had to cut your way through them with a knife; and great ferns and rushes, big as an oak and tall as a steeple, grew in the swamps of Indiana and Illinois. Their green plumes were so long and so densely interwoven that the Man of the Moon might have fancied that the earth was feathering out. Then all about, huge reptiles, with jaws like the gates of doom and teeth like cross-cut saws, and little reptiles with wings like bats, crawled, and swam, and flew.

But the ferns died, and the reptiles died, and the rush-trees fell in the swamps, and the Illinois and the Sangamon and the Wabash and all the other rivers covered them up. They stewed away under layers of clay and sand, till at last they turned into coal and wept bitter tears of petroleum. But all this while Favosites lay in the rocks in Wisconsin.

Then the mists cleared away, and the sun shone, and the grass began to grow, and strange animals came from somewhere or nowhere to feed upon it. There were queer little striped horses, with three or four hoofs on each foot, and no bigger than a Newfoundland dog, but as smart as ever you saw. There were great hairy elephants with teeth like sticks of wood. There were hogs with noses so long that they could sit on their hind legs and root. And there were many still stranger creatures which 
no man ever saw alive. But still Favosites lay in the ground and waited.

And the long, long summer passed by, and the autumn and the Indian summer. At last the winter came, and it snowed and snowed, and it was so cold that the snow did not go off till the Fourth of July. Then it snowed and snowed till the snow did not go off at all. And then it became so cold that it snowed all the time, till the snow covered the animals, and then the trees, and then the mountains. Then it would thaw a little, and streams of water would run over the snow. Then it would freeze again, and the snow would pack into solid ice. So it went on snowing and thawing and freezing, till nothing but snow-banks could be seen in Wisconsin, and most of Indiana was fit only for a skating-rink. And the animals and plants which could get away, all went south to live, and the others died and were frozen into the snow.

So it went on for a great many years. I dare not tell you how long, for you might not believe me. Then the spring came, the south winds blew, and the snow began to thaw. Then the ice came sliding down from the mountains and hills, and from the north toward the south. It went on, tearing up rocks, little and big, from the size of a chip to the size of a house, crushing forests as you would crush an egg-shell, and wiping out rivers as you would wipe out a chalk-mark. So it came pushing, grinding, thundering along, - not very fast, you understand, but with tremendous force, like a plough drawn by a million oxen, for a thousand feet of ice is very heavy. And the ice-plough scraped 
over Oconto, and little Favosites was torn from the place where he had lain so long; but by good fortune he happened to fall into a crevice of the ice where he was not much crowded, else he would have been ground to powder and I should not have had this story to tell. And the ice melted as it slid along, and it made great torrents of water, which, as they swept onward, covered the land with clay and pebbles. At last the ice came to a great swamp overgrown with tamarack and balsam. It melted here; and all the rocks and stones and dirt it had carried, - little Favosites and all, - were dumped into one great heap.

It was a very long time after, and man had been created, and America had been discovered, and the War of the Revolution and the War of the Rebellion had all been fought to the end, and a great many things had happened, when one day a farmer living near Grand Chûte, in Outagamie County, Wisconsin, was ploughing up his cloverfield to sow to winter wheat. He picked up in the furrow a curious little bit of " petrified honeycomb," a good deal worn and dirty, but still showing plainly the honey-cells and the bee-bread. Then he put it into his pocket and carried it home, and gave it to his boy Charley to take to the teacher and hear what he would say about it. And this is what he said. 


\section{AN ASCENT OF THE MATTERHORN.}

A $\mathrm{N}$ old miner of ' 49 whom I once met in 1 California said to me, as we came in sight of the snowy crests of Tuolumne and Calaveras: "These mountains are not appreciated in California. We used to dig and dig in them, and that was the end of it. The fact is, stranger, a man ought to have two lives, - one to get a living in, the other to look at the mountains."

But there are some on whom the mountains have the first claim; and so there has arisen the Alpenclub, - the guild of mountain-lovers whose. "feet are beautiful upon the mountains," and to which such men as De Saussure and Agassiz and Tyndall and Balfour have been proud to belong.

And thus it happened that on the tenth day of August, I88I, a party of young people from Indiana, mountain-lovers of varying degrees, walked over the snowy pass called the Matterjoch, which leads from Italy across the Pennine Alps into Switzerland. And ever before us and above us as we came up the green valley of Tournanche, ever before us as we toiled up the pass, - above us everywhere, dark, majestic, inaccessible, rose the huge pyramid of the grandest of the Alps. No one who has ever seen it can ever forget its form. It burns itself into the memory as nothing else in all 
Europe does. Shut your eyes for a moment, you who have been at Zermatt, and straight before you and above you, its long hand clutching at the sky, you will see the Matterhorn! It is not the highest mountain of the Alps. Its gigantic neighbors Monte Rosa, the Mischabelhorn, the Weisshorn, as well as Mont Blanc - are all higher, - a little; but no other mountain in the world makes such use of its height as the Matterhorn. Other high mountains have great rounded heads, white with the snows of eternity. Their harsher angles are worn away by the long action of the glaciers. But the Matterhorn is a creature of the sun and frost. No glacier has worn its angles into curves. Its slopes are too steep for snow to cling to, and all the snow which winter or summer falls upon it rolls down its sides and lies in three great iceheaps at the bottom. These are the Furggen glacier, the Matterhorn glacier, and the glacier of Tiefenmatten.

We had wandered about Zermatt for a day or two, seeing the sights in the usual way, and all the while the Matterhorn hung above our heads and dared us to come. At last we could stand it no longer; and one evening when the "stalwarts" were gathered together on the stone-wall in front of the Hôtel Monte Rosa, Gilbert said unto Beach, "We must do something big before we leave this place. Let us go up the Matterhorn!" And Beach said, "We must indeed. I will go if Jordan will."

But Jordan felt doubtful. He knew that a mountain which eclipsed the full moon would be a hard 
road for a heavy man to toil up. Besides, the story of the first climbers was fresh in his mind. But the boys were persistent, and they said, "You have talked and talked about mountains, and you have never done a single big thing among them; and it is time you did!" And so they kept it up. And I remembered that Tyndall had thought it worth his while to try again and again to go up this mountain, and so had my Italian namesake, the geologist Giordano. Then why not I?

At last we three shook hands upon it, and went back to the hotel to make arrangements. Afterwards three others joined us, making six in all. ${ }^{1}$ And we sought out "John the Baptist," and made him our chief guide, and directed him to provide food and ropes for eleven, and we were "in for" the Matterhorn.

Meanwhile the boys wrote letters home, - letters full of descriptions of the Matterhorn, which kept their mothers and sisters awake o' nights for a week. And the sketches of the mountain with which they embellished them were wonderful to behold. In the evening some of them strolled out to the little graveyard at Zermatt, - to the tombs of Hadow, Hudson, and Michel Croz, the first victims of the Matterhorn, - " for inspiration," they said; and some of them composed epitaphs, which they have not yet needed.

At one o'clock the next morning the porter of the Hôtel Monte Rosa knocked at our doors, and

1 Professor Charles H. Gilbert, Professor Melville B. Anderson, Mr. William W. Spangler, Mr. William E. Beach, Mr. Walter O. Williams, and the writer. 
announced that breakfast was ready. We rose in a hurry, ate everything on the table, - our invariable custom in Switzerland, - and by half-past one our alpenstocks were rattling loudly on the stone pavements of the narrow streets of Zermatt. Our five guides were ready, each laden with ropes, ice-axe, and provisions, and we were on the road up the mountain.

Let me say a word about the guides. Most of the able-bodied men in the Swiss valleys are in the summer guides or porters in the mountains. The average guide is a rather heavy, slow-spoken fellow, who buys a good deal of food for you and eats it himself, who drinks great quantities of villanous sour red wine at your expense, hauls you around like a bundle of meal, and finally, as he leaves you, waxes eloquent on the subject of Trinkgeld. But there are guides and guides, and some of them are men of force and intelligence, who have, and who deserve to have, a wide reputation. Among those, known all over Europe for strength and courage, was Michel Croz of Chamouny, who fell from the Matterhorn in 1865 . Among those destined to be thus known is the young man whom we fortunately selected as our chief guide, - Jean Baptiste Aymonod of Val Tournanche.

"John the Baptist," as we called him, is a very robust and muscular young man of medium height, with a smooth face, light hair, gentle, blue eyes, and a firm, expressive mouth. He is soft-voiced and slow-spoken, - as are most of the Swiss guides, and he is endowed with a graciousness of manner and purity of speech hardly to be looked for in a 
herdsman's boy, risking his life on the rocks and ice for two hundred dollars a year. His face shows the effects of mountaineering, for his nose has sometime been broken by a falling stone.

Our next guide, Victor Maquignaz, is older than John, and larger, - a big burly mountaineer, brave and trusty, who speaks French with variations, a surprising dialect born of the mountains, in a high, uncertain falsetto, like the voice of a wheelbarrow that needs oiling. Next came François Bic, - a tall, intelligent, positive fellow, a good mountaineer, but who would be better liked if his eye were less closely fixed on the Trinkgeld. Next came his brother, Daniel Bic, - a muscular man in full beard and spectacles, looking like a German Doktor, who had never been up the Matterhorn before, and evidently wished never to go again. Finally, there was Elie Pession, whom we surnamed "the Invalid," - a strong-looking fellow with a heavy black beard, whose heart sank into his boots when he stood in the presence of danger.

All these guides were French, and all belonged to the valley of Tournanche, - the deep valley which extends to the southward from the Matterhorn on the Italian side, corresponding to the valley of Zermatt, which extends on the Swiss side toward the northward.

As we started out that night, it seemed that we had never seen the world look so beautiful. The moon was full, and hung gracefully over the left shoulder of the Matterhorn, and the sky was without a cloud. Through dark fir-forests we went, by the side of a foaming torrent, then over flower-carpeted 
pastures and steep grassy slopes, the great mountain ever in front and the glistening snows of the Dent Blanche and the Breithorn flanking it on either side.

At sunrise we came to the first cabin, at the foot of the upper pyramid of the Matterhorn, on a narrow crest of rocks which separates the Furggen glacier from the Matterhorn glacier. This cabin, built by the Swiss Alpenclub, is quite a comfortable place, with plenty of straw, blankets, and fuel. Many who climb the mountain spend the night here, setting out at sunrise for the summit. The walls of the cabin are covered with lead-pencil inscriptions in every tongue. One of these, in particular, is noteworthy as being higher above the sea-level than any other poetry in the English language.

\author{
"Little Matt Horner \\ Sat in the corner, \\ And vowed he would not be climbed: \\ We tried it, you know, \\ But found so much snow \\ We very politely declined."
}

This is not much as poctry; but it is worthy of notice that in a climate and at an altitude in which ordinary spring poetry is frozen through and through in a minute, this little blossom has survived.

For a few moments we watched the sun rising over the glaciers of the Weissthor pass, and then John the Baptist had us again under way. We stood right at the foot of the mountain; but the nearer we came the steeper it looked, and there 
was no sign of a possible path. Precipices of bare, loose rocks, with gullies filled with snow and slippery ice, were before us, and nothing else. We went on a little way until we came to a snowy ridge, on which was a heap of large stones. "This," said John the Baptist, "was the chalet of Monsieur Whymper." Then the path began to grow narrow, and abysses opened below us. John called a halt, and said that we must now be very careful; we must watch nothing but our feet; we must talk as little as possible; we must keep our mouths shut and breathe through our noses; and finally, we must chew chocolate or caramels all the time, for this, he said, would keep our throats from being parched. This began to look like serious work; so we left off looking at the sunrise and the glaciers, watched our shoes, chewed our chocolate, and moved on.

The path started out along a shelf of rock about a foot wide, the surface of which, in accordance with the southward dip of the strata, slanted toward the mountain. Above the path was a wall of rock some ten feet high, and at the top of this was a similar shelf, but somewhat broader than the one on which we were walking. Below us was a slippery wall of rock, perhaps a hundred feet high, at the foot of which lay the ice of the Furggen glacier. In summer the glacier slides away from the mountain, the supply of snow not being great enough to balance its loss by melting. Between the mountain and the glacier is therefore a deep chasm, or Bergschrund, - a damp, chilly, uninviting looking placc, bordered on one side by 
rocks, on the other by blue ice, from the edge of which often hang long icicles. We walked on in silence above this Bergschrund, thinking that our way would be easier by-and-by, when suddenly our path ceased. At this point John the Baptist left us, and climbing fly-like up the side of the rock, he showed us our path about ten feet higher up on another shelf formed by a projecting stratum. He threw the end of his rope to the guide Victor, who put it around his waist. Then John stood in the attitude of the Colossus on the edge of the precipice, and hauled him up. Next came my turn, and I dangled serenely over the edge of the mountain, while John and Victor pulled on the rope. This mode of mountain climbing gives a view that you can get in no other way of the mountains on the other side. And so one by one came up the rest.

But our path did not improve as we went on. From this point to the top, about six hours' climb, there was not a single yard of level walking or, indeed, of any walking at all. One could not anywhere take three steps without watching each step and making a mental calculation as to whether his feet would hold. There was hardly a place where a stumble or a slip of the foot would not, except for the help of others, send the person who slipped to the foot of the mountain. Every step was on the edge of a precipice, and every step made the precipice higher, - though there is little real choice between falling a hundred feet and falling a mile. The boys appreciated this, and fell not at all. They clung with fingers and toes to every 
projecting point, and nothing short of an earthquake could have gotten that mountain away from them.

I have called the Matterhorn a creature of the sun and frost. It is now but a wreck, - the core of a far greater mountain whose rocks have been hurled down into the valleys by the "strong gods" of the sun and air, and have thence been scattered over Switzerland and Italy by the glaciers of the Great Ice Age. It stands in the altitude of perpetual frost, but bathed by the warm sunshine of Italy. On every clear day its rock sides become warm in the sun. All ordinary clouds are below its summit, and each cloud that touches it in summer covers its surface with light snow. Then this snow melts again in the sunshine, and causes water to trickle in all the joints and clefts of the rocks. Then at night the mountain grows cold, - in clear nights intensely cold, - the water freezes in these fissures, and expanding widens them, thus pushing the outermost blocks of rock nearer and nearer the edge of the precipice. At last a gust of wind or a careless foot may cause one of these loose rocks to topple over. Down it falls, loosening many more on its way, the whole series plunging with an everincreasing roar till it reaches the ice of the Furggen glacier. Into the glacier the falling rocks dive, scattering the ice masses, as a stone thrown into a pond causes the water to spatter. Once in the ice the stones move on more leisurely, until after years they reach the point where the glacier melts and gives up its dead, when they pass into the universal rubbish-heap, - the moraine, at the bottom. These 
are the pierres qui roulent, - " the stones that roll," the dread of the mountaineer. Most high mountains are fashioned by the glaciers themselves; but the glacier has no hold on the Matterhorn. Glaciers make white domes of mountains; frost makes black pinnacles and spires.

The guides had now tied us together, and the value of the rope in mountaineering soon became very evident to us. In all difficult or dangerous excursions in the high Alps, the persons making the excursion are tied together by ropes. Usually four or five are joined to one rope, the rope being tied around the waist of each. It is the duty of each one to see that the rope below him is kept drawn tight, so that if any person happens to stumble or slip, the aid of the others will keep him on his feet. In very difficult excursions, like the one here described, usually but one person moves at a time, the other three on the rope each holding his position as well as possible until the fourth one has reached a position of safety.

The way we went was in most cases like this. First John the Baptist would scramble up some ledge of rocks, clinging by fingers and toes to projecting points, or reaching some higher crag by means of his ice-axe. When he found a suitable foothold he would shout to me, and I would crawl up to his position, while the next man would edge up to where I was, - and so on. When we came to a specially bad place, a mausais pas, where the rocks were unusually loose and the hold precarious, I would shout up to him before following him, "Êtes-vous bien placé?" ("Are you well 
placed?") If John was "well placed" he would shout, "En avance!" ("Come on!") I would then call out, "Tirez!" ("Pull!") He would then draw up on the rope, which action made it much easier for me to scramble up than it would have been without this assistance. Then it became my turn to help up the next man; but he usually crawled up unaided, - having an aversion to being helped, which I did not share, but for which I was duly thankful.

After working along in this way for about three hours, John the Baptist told me to look up and I would see the upper hut and the ropes which came down from it. High above us we could see a little stone shanty under the shelter of a huge pinnacle of rock on the edge of a sharp precipice some fifty feet high. Down this precipice hung a rope, fast to an iron staple above, swinging loosely below. We had read in the guide-books that " ropes have been placed in the more difficult places on the Matterhorn." We had imagined something such as we had seen in other mountains, - a rope railing alongside of a steep and narrow path. We were hardly expecting to go up hand over hand on a rope swinging loosely over infinity.

John the Baptist started up on the rope, resting his toes on the projecting points of the rocks, where opportunity offered, until he reached a little shelf, an inch or two wide, where he could stand on one foot. It was growing very cold; the rope was white with frost. I put on my gloves and climbed up for a little distance; but when I came to rest my full weight of two hundred and ten pounds on 
the rope, my gloves would not cling to it. I felt myself slowly sliding downward. It was not a pleasant sensation. I thought that I should probably stop on reaching the knot on the end of the rope; but I might go too fast, and, jerking John the Baptist from his narrow perch, we would form the nucleus of a small avalanche moving towards Zermatt. But I stopped, and taking off my gloves I tried it again, - this time with better success.

At last, after a long and toilsome scramble we all reached the upper hut, where we lay down on the hay for a little rest and another round of tough bread, sour wine, and chocolate. This hut I shall have occasion to describe farther on.

As we went on, clouds had begun to gather about us, and after a little the wind rose and it began to snow. We lost sight of the earth altogether, and everything below us became a bottomless abyss. Soon we came to the narrow ridge on the shoulder of the Matterhorn where for a short distance the northeast angle of the mountain which we were ascending is no wider than the back of a very lean horse. It is too narrow for one to stand on or even to sit on with comfort. On either side as we crawled along we could look downward seemingly to the very bottom of things. Above this point the first climbers fell from the mountain. I asked John about it, but he would not talk. "I was not here then," he said.

After this we came around to the eastern face again. Here we could see the summit, some five hundred feet above us, - a ragged wall of rock, steeper than any slope we had yct ascended and its 
top still seeming to hang over our heads. How to get up was evident from the long lines of hanging ropes. We went up these slowly, one after another; and at last we came to prefer these ledges with their ropes to the lower slopes, which, although less steep, offer nothing but rocks and snow to cling to. One of these ropes had had one of its strands cut by the sharp edge of some rock, and the other two strands were partly untwisted. This rope may break for somebody, but it did not break for us.

It is hard enough to climb this part of the mountain with the aid of the ropes. It seems next to impossible without it; yet some one carried up these ropes and the iron staples by which they are hung, and fastened them all there. The man who did this was John the Baptist. At last the ropes ceased, and crossing over to the north side of the mountain, we found there an easier slope by which we soon reached the summit. It was now a little after noon.

The top of the mountain is a narrow crest, lying nearly east and west and rising toward a point on the Swiss side. This crest is about twenty feet long and from one to three feet wide. Its north side is a rocky slope, while the south side is nearly perpendicular, and at the time of our visit it was covered with a long overhanging snow-bank or "cornice." It was as cold as midwinter. The. north wind whistled and howled, so that we dared not rise to our feet, and the snow fell thick and fast. I should hardly say that the snow fell; it is made up there, and every cloud which touches the mountain is a snow-storm. Most of the time 
we could see nothing; the whole earth was represented by the little summit-ridge, which was all that we could see of the Matterhorn. Once in a while a little eddy in the clouds on the south side of the mountain would give us a glimpse of Le Breuil and the valley of Tournanche two miles below us; and occasionally our nearest mountain neighbor, the Dent Blanche, disclosed her snowcrowned head.

We did not stay long on the summit. It was not very warm, and we wished to give the others a chance. We wrote our names on a card, and placed it in an empty bottle which the mountain keeps as a register for visitors. Victor broke off with his ice-axe the uppermost point of the mountain, a piece of dark green hornblende. I put this in my pocket as a trophy, and we were ready to descend.

In going downward, our motion was much like that of one of the caterpillars or " measuring-worms" which come upon the maple-trees in the spring. The strongest guide in each section was placed last in the series, so as to be "well placed," and to hold the others back in case any one should slip. This guide starts first in each series, and goes down to the niche of the next man below him. When he is again "well placed," the next man advances, and in turn the third and the fourth, - the one standing lowest moving where it is possible the length of one section of the connecting rope, after which the others again edge downward to him. The progress is of course very slow, and three fourths of the time each man is engaged in resting, with his. 
heels "well placed" on some projecting shelf of rock.

At times in our descent we felt the force of the tourment, a wind peculiar to the high mountains, - a sort of snow-laden whirlwind, or "wind made visible." This wind goes furiously over the mountain-side, tearing off loose rocks, starting avalanches, and tossing about the banks of snow. Whenever one of these struck us, we lay flat and clung to the rocks, lest we should be literally blown off the mountain. One of our company, I remember, wore a narrow brimmed hat drawn down tightly over his ears; the tourment took it and whirled it high into the air. The learned professor fell flat on the ground, while every hair of his head caught the rotary motion and stood straight out.

As we went farther, we noticed more and more the treacherous character of the stones on the mountain side. The whole outer coat of the mountain is loose, scarcely a rock anywhere on the Swiss side being firmly attached. Into all the joints of the strata the water from the melting snow finds its way, and by the freezing of this water the joints are widened and the blocks of hornblende are daily pushed nearer and nearer to the edge. Thus nothing is firm; nothing is stable, and each year the mountain offers a new face to the weather.

Going down the mountain is more difficult than going up. This is not only on account of the mental strain of constantly looking over precipices, but because of the looseness of the rocks. Stepping down on a stone, one is more apt to detach it than 
when he cautiously clings to it from below. However careful we may be, some stones will fall; and while this may not hurt us, it may hurt some one below us. Then occasionally some stone would detach itself naturally, and go rattling down to the bottom of the mountain, followed by a host of smaller ones, leaving as they pass a strong "smell of sulphur," which, as Whymper says, "tells us who sent them."

The Matterhorn, as I have said, is one of the steepest and slipperiest of mountains, and everywhere it offers but scanty hold to the climber. There is, however, in all this little real danger to men strong of limb and steady of head, accompanied by good guides. But there is one danger which is real, one which is almost constantly present and against which no skill nor strength can wholly guard, - and that is the danger from falling stones. This risk would be slight with a small party, but our company of eleven, probably the largest ever on the Matterhorn, made so long a line that a stone loosened by the uppermost would acquire a fearful velocity before reaching the last. Not more than five persons should be on the Matterhorn at once.

The head of our column had reached the foot of one of the last ropes which come down from the summit, and was waiting for the others to descend. One of the very last in the company was laboriously crawling over a large projecting rock, when it suddenly became loosened. I remember hearing some one scream "Look ouT!" and then suddenly it seemed to me that all sunshine and hope 
had gone out of the mountain. The great rock fell about thirty feet. Striking a lower shelf, it broke into three or four pieces. One of these, weighing about a hundred pounds, flew over my head and over the heads of John and Victor. The man below us had turned to look back when he heard the noise; the rock struck him in the face, knocked him instantly off the ledge and out of our sight, and then plunged down the side of the mountain.

We were all paralyzed for an instant, - the guides as well as the rest. I remember calling to John to give me rope, so that I could go down to Victor, and let him go down to Gilbert. By the time we got down, Gilbert was struggling to his feet. He had fallen as far as the rope would let him. His face and clothes were covered with blood which flowed from a deep cut like a sabre gash across his nose and forehead. A stiff-brimmed hat. which he wore had been cut fairly in two, and its resistance had helped to weaken the force of the blow. We decided that no bone was broken, although the wound was a most serious one. Once at the bottom, we could take care of him perhaps; but should he faint, or be unable or unwilling to walk, we should have a difficult task to carry him down. We tied up the cuts with all the silk handkerchiefs in the party, covered them with snow, and put over them all a thick woollen hood, which John the Baptist carried for use in time of need. In five minutes we were moving again. We were unable wholly to stop the flow of blood, and our course was marked by a red trail. Gilbert's face was soon entirely covered by a red clot; his eyelids swelled 
so that he could not see, and after a little he lapsed into a half-unconscious state, in which he seemed to realize only that he had fallen from the mountain, that it was very cold, and that he must always walk. And at times he would give up and lie down in the snow, when we would use every argument in our power to induce him to rise and go on again. It took us four hours to reach the upper cabin, a distance perhaps equal to two "squares" in a city street.

Had our wounded man been otherwise than light of weight, strong of limb, and immensely resolute, we might not have gotten down at all; and a night on the bare side of the mountain meant simply freezing to death. It is hard enough for a well man to go safely down the Matterhorn, far harder than to go up; but for a man blind and faint, it became terrible. "C'est un homme fort et brave" ("He is a man brave and strong"), said John the Baptist. If Gilbert had been as heavy as I, we should have had a task indeed. I remember thinking at the time that it was fortunate that I was n't hit.

At one time I saw Gilbert slip, and with Victor, who half led, half carried him, fall like a shot. But John the Baptist was always "well placed" and held them. At another time we heard a terrible uproar, and three or four rods away we saw an immense avalanche of stones coming down. This was made of a dozen large rocks of the size of a wagon, with hundreds of little ones yelping in the rear. It was a grand sight; but we were little in the mood for it. "C'est une montagne terrible" ("It is a terrible mountain"), said John the Baptist. 
The guide Pession had been in a shiver of mortal terror ever since the accident, and for the rest of the day was worse than useless. "You must pardon him," said John the Baptist, "for he has a wife and children in Val Tournanche."

At seven o'clock we reached the upper hut. We put Gilbert on the hay; after which he refused to move, and soon went to sleep. John decided to remain there over night, with Victor, Spangler, and myself, and to send the others down to Zermatt. After many adventures, which I need not here relate, the others reached the bottom in safety. Meanwhile, we five arranged for lodgings in the upper hut, some thirteen thousand feet above the sea, one of the highest "houses" in Christendom.

This hut is simply a pile of stones more like the den of some beast than a cabin. It is built between a pinnacle of rock and a precipice, its stone roof. rising in a slope from the edge of the latter to the former. The height of the room within is perhaps five feet on the highest or upper side. Its length is some ten feet, and its width about six. On the south end is a little door or hole for entrance, and on the floor on the north end are three coarse blankets and a few armfuls of hay. A little bench, a small table, a tin-pail, and a basket of shavings complete the equipment.

John the Baptist sent us to bed at once, - one on each side of Gilbert, to keep him warm. But nobody kept us warm. Our clothes were wet, and my off side was against a frosty rock, which carried away heat faster than I could generate it. The young man in one of Grimm's fairy-tales, who 
"did not know how to shiver," would certainly have found the coveted experience there. We did little else all night long. Moreover, the floor was very uneven, and the tin wine-flask which did duty as a pillow was far from being "soft as downy pillows are." There was not much encouragement for sleeping. All night long our patient kept on ascending mountains, and recalling his experiences of the day. At about the first watch of the night, he shouted out, "Attention! Attention toujours!" At another time he called us all up with this remark, "Here we will stop walking and take wheelbarrows." When everything else was quiet, the snow thawed on the roof and kept little streams of sooty water trickling over our faces. John and Victor lay on the bare ground; and at intervals, when they could stand it no longer, they would kindle a fire of shavings, and wake us up to take a drink around of chocolate.

I have seen cold nights elsewhere, but nothing to compare with this. The storm ceased early in the night, the clouds blew over, and a sharp, crystalline midwinter coldness penetrated everywhere. We could every few minutes hear the mountain snap, as the water froze in the fissures of its rocks. I sometimes spend the night now-a-days waiting for a belated train in the little hotel of some prairie "railroad junction" in Indiana or Illinois, at the time of the January blizzards. The single window in the little bedroom will fit loosely in its place. One pane of glass may be replaced by an old hat, the second by a newspaper, and a third be wanting altogether. The bed may have but one sheet, a 
hard husk mattress, and an insufficient equipment of comfortless quilts, as heavy and as warm as though made of sheet-lead. With all these conditions and worse as I have sometimes found them, I have now only to lie still and think back to that night on the Matterhorn, and the whole atmosphere becomes fairly tropical.

In the morning we rose early and went out to look at the sunrise. The air was intensely clear. The whole Matterhorn was white with new-fallen snow and glistening with frost. Far below us the clouds hung white and heavy over the valley of Zermatt, their thick folds hiding all of the landscape which was not snow-covered, their upper outlines seemingly continuous with the white surface of the great glaciers. Far beyond the valley of Zermatt rose the giants of the Oberland. Nearer to us were the Dent Blanche, the Weisshorn, the Rothhorn, the three peaks of the Mischabel, and to the right of these the Allalin, the Strahlhorn, the Rympfischhorn, and a host of other "horns," named and unnamed, rose before us. To the east was the long crescent of Monte Rosa, the Cima di Jazzi, the Lyskamm, Zwillinge, and Breithorn, with the great Gorner glacier winding about their feet. It was the sight of a life-time, which can never fade from the memory.

"With drifts of snow, fantastic wreath on wreath; And peak on peak against the turquoise blue, The Alps like towering campanili stand, Wondrous with pinnacles of frozen rain, Silvery, crystal, like the prism in hue.

Oh. tell me, love, if this be Switzerland, Or.is it but the frostwork on the pane?"-ALDRICH. 
Our invalid was better in the morning, but cold, disgusted, and impatient. His swollen eyelids each looked like a ripe plum. He said that he could not open his eyes. I told him to lie still and keep them shut then, - a remark which he thought peculiarly unfeeling. We decided to send this Knight of the Sorrowful Figure with John and Victor down to Zermatt, while Spangler and I would wait and play " mumble-the-peg" until their return, which might be next day and might be - never! Not a cheerful prospect; but, as the jester said in the woods of Arden, "Travellers must be contented."

" Before they had fairly started, however, we heard shouting from below; and soon the two guides Bic reached us from the lower cabin, in which they had spent the night. We therefore again moved on, but very slowly. The new-fallen snow made the walking very difficult, and much sitting down in slippery places reduced our clothing to a total wreck, concerning which the less said the better. There were many "mauvais pas;" but we passed them all at last, and towards noon we reached the lower cabin. The doctor from Zermatt was there, and also four able-bodied ruffians bearing a sedan-chair. We were now safe at last; and after another drink around of chocolate, - there was nothing else left, - we started for Zermatt.

Our welcome in the village was most enthusiastic. Everybody - English, German, French was delighted to see us, and the "Matterhornbesteiger" were the heroes of the hour. In the 
chapel at Zermatt prayers were offered for the Queen of England and on our account for President Garfield, and thanks were given for our safe return.

As for our own party, an Englishman who was there afterwards said: "I never saw anything like it. Every one of those Americans rushed right out into the street and crowded around, and I actually thought that every one of those ladies was going to kiss the Professor!"

But not one of them did!

I afterwards received from "John the Baptist" the following letter, which will be of interest as the composition of an illiterate but very intelligent man. I give it literatim. It will be noticed that while the construction of the sentences is generally correct, the words are mostly spelled by ear, not an easy thing to do in the French language.

Monsieur Jordan.

Valtournenche, le i6 Decbre, i $88 \mathrm{I}$.

Cher Monsieur, - J'ai reçus vôtres lettres le 15 courent, laquelle a été pour moi un grand plaisir, premièrement en aprenant que $\mathrm{M}^{\mathrm{er}}$. Gilbert était parfaitement géri. Je regretais toujours de ne pa vous avoir prié de me donner de ses nouvelles en arivents dans vôtres patrie. Je vous prier de le saluer bien de ma part, et en même tempts le remercier du cadou que vous m'avez remis en son nom à Saas. En second lieu je vois avec plaisir que vous ne vous êtes pas contenter de me payer largement mes servisses de l'été passé. Vous voulez encore travailler pour me donner une renomée parmi les Américains, s'est plus que je ne merite. Je vous en remercie infiniment. Je regrete beaucoup d'être dans l'impossibilité de pouvour vous en rendre le reciproque. Je ne 
peut faire autre chose que de vous souéter des jours heureux plain de Santées et d'Amour pour les Alpes Pennines. .. Je vous prie de saluer toutes l'honorables compagnie que vous aviez avec vous l'été passé. Maquignaz et les Bics vous font ses salutations.

Recevez une bonne poigné de main de celui qui voudroit être longtents

Vôtre serviteur,

Aymonod Baptiste. ${ }^{1}$

1 The following is a translation of this letter :-

Mr. JORDAN.

Val Tournanche, Dec. 16, is8i.

DEAR SIR, - I have received your letter of the fifth current, which has been for me a great pleasure, firstly in learning that $\mathrm{Mr}$. Gilbert was perfectly cured. I regretted always not to have asked you to give me news from him in arriving in your own country. I pray you to salute him well for my part, and at the same time to thank him for the present which you gave me in his name at Saas. In the second place, I see with pleasure that you have not contented yourself with paying me liberally for my services of last summer. You wish still to work to give me a fame among Americans. It is more than I merit. I thank you for it infinitely. I regret much being in the impossibility of being able to render you a reciprocal service. I can do nothing more than to wish you happy days full of health and of love for the Pennine Alps. ... I pray you to salute all the honorable company which you had with you last year. Maquignaz and the Bics send you their salutations.

Receive a good shake of the hand from him who would long be

Your servant,

Aymonod BAptiste. 


\section{THE STORY OF A STRANGE LAND.}

In one strange land, And a long way from home,

I heard a mighty rumbling, and I could n't tell where.

Negro Melody.

A LONG time ago - fifty thousand years ago A perhaps, or it may have been twice fifty thousand-a strange thing took place in the heart of the Great Mountains. It was in the middle of the Pliocene epoch, - a long, dull time that seemed as if it would never come to an end. There was then on the east side of the Great Divide a deep rocky basin surrounded by high walls of granite gashed to the base by the wash of many streams. In this basin, we know not how, - for the records all are burned or buried, - the crust of the earth was broken, and a great outflow of melted lava surged up from below. This was no ordinary eruption, but a mighty outbreak of the earth's imprisoned forces. The steady stream of lava filled the whole mountain basin, and ran out over its sides, covering all the country around so deeply that it has never been seen since. More than four thousand square miles of land lie buried under melted rock. No one can tell how deep the lava is, for no one has ever seen the bottom. Within its bed are great clefts whose ragged walls 
descend to the depth of twelve hundred feet, and yet give no glimpse of the granite below, while at their side are mountains of lava whose crags tower a mile above the bottom of the ravines.

At last, after many years or centuries, - time does not count for much in these Tertiary days, the flow of melted lava ceased. Its surface cooled, leaving a high, uneven plain, black and desolate, a hard, cold crust over a fiery and smouldering interior. About the crater lay great ropes and rolls of the slowly hardening lava, looking like knots and tangles of gigantic reptiles of some horrible extinct sort. There was neither grass nor trees, no life of any sort. Nothing could grow in the coarse black stone. The rivers and brooks had long since vanished in steam, the fishes were all dead, and the birds had flown away. The whole region wore the desolation of death.

But to let land go to waste is no part of Mother Nature's plan. So even this far-off corner of her domain was made ready for settlement. In the winter she sifted snow on the cold black plain, and in the summer the snow melted into a multitude of brooks and springs. The brooks gradually wore paths and furrows down the lava bed, and the sands which they washed from one place they piled up in another. The winds blew the seeds of grasses about, and willows and aspens crept up the mountain-sides. Then came the squirrels, scattering the nuts of the pine. Other seeds came, too, in other ways, till at last the barren hillside was no longer barren.

The brooks ran over the surface of the crust 
undisturbed by the fires within, and were clear and cold as mountain brooks should be; but the rain and melted snow will never all remain on the surface. Some of it falls into cracks or joints or porous places in the rock, and from this conse underground streams or springs. But in this region a stream could not run long underground without coming in contact with the old still-burning fires. When a crust is formed over the lava, it cools very slowly. When the crust is a rod or two deep, the lava within is almost as well protected as if it were at the centre of the earth.

Whenever the water came down into the fire, the hot rocks would be furious with indignation, and tearing the water to atoms they would throw it back to the surface as steam. Then the explosive force of the steam would in turn tear up the rocks, making still larger the hole through which the water came. When the rocks were very hot, a little water upon them would make a terrible commotion like the shock of an earthquake. When much water came down, it would hiss and boil high in the air, as it tried to break the cushion of steam which came between it and the lava.

And all this went on in hundreds of places and maybe for thousands of years. The hot rocks glowed and sweltered in the ground, and the cold snow-water crept after them closer and closer, while more and more vigorously the rocks resented the intrusion. Sometimes the water would go down in a mass through a cleft, when it would be hurled back bodily the very way it came. At 
other times the water came down little by little, insinuating itself into many places at once. Then the hot rocks threw it back in many little honeycomb channels, and by the spreading of these channels the rocks were at last crumbled to pieces. The hard black lava or the glass-like obsidian were changed to white kaolin as soft and powdery as chalk. And as the water fought its way, gaining a little every year, steadily working between the joints in the enemy's armor and as surely being thrown back with violence if it penetrated too far, the animals and the plants followed in the wake of the water, and took possession of the territory as fast as it was won.

At last the Pliocene times were over, for all times come to an end. The one sure thing on the earth is the certainty of change. With the change of time came on the earth's great winter. The snow-drifts on the lava were piled up mountainhigh. Snow is but ice in little fragments which will grow solid under pressure. As the snow accumulated it began to move, forming great rivers of ice which ran down the courses of the streams. And as these slowly moving, gigantic ice-rivers tore away huge blocks of lava and pushed them down the mountain-sides, where the rocks had been softened by the action of steam, the ice wore out deep valleys, and everything that it touched was smoothed and polished. The winter of the great Ice age lasted a very long time, many thousands of years; but, long as it was and long ago, it came at last to an end, - not to a full stop, of course, for even now some of its snow still 
lingers on the highest peaks that surround the lava-beds.

Then the winters grew shorter and the summers longer. The south winds blew, and the ice melted away, first from the plain and then from the mountains. The water ran down the sides of the lava-bed, cutting deep gorges or cañons, so deep that the sun can hardly see the bottom. And into the joints and clefts of the rocks more and more water went, to be hurled back with greater and greater violence, for all the waters of all the snow cannot put out a mile deep of fire.

In the old depressions where the ice had chiselled away the softer rocks, there were formed lakes of the standing water, and one of these was more than thirty miles long, winding in and out among the mountain-ridges. In the lake bottom the water soaked through down to the hot lava below, from which it was thrown boiling back to the surface again, fountains of scalding water in the icy lake.

The cold Ice age had killed all the plants in the region; it had driven off the animals that could be driven, and had then buried the rest. But when the snow was gone the creatures all came back again. Grass and meadow-flowers of a hundred kinds came up from the valleys below. The willow and the aspen took their place again by the brookside, and the red fir and the mountain pine covered the hills with their sombre green. The birds came back. The wild goose swam and screamed, and the winter wren carolled his bright song, - loudest when there seemed least cause for rejoicing. The beaver cut his timber and patiently 
worked at his dams. The thriftless porcupine destroyed a tree for every morning meal. The gray jay, the "camp-robber," followed the Indians about in hope that some forgotten piece of meat or of boiled root might fall to his share; while the buffalo, the bear, and the elk each carried on his affairs in his own way, as did a host of lesser animals, all of whom rejoiced when this snowbound region was at last opened for settlement. Time went on. The water and the fire were every day in mortal struggle, and always, when the water was thrown back repulsed, it renewed the contest as vigorously as before. The fire retreated, leaving great stretches of land to its enemy, that it might concentrate its strength where its strength was greatest. And the water steadily gained, for the great ocean ever lay behind it. So for century after century they wrestled with each other, the water, the fire, the snow, the animals, and the plants. But the fishes that had once lived in the mountain torrents were no longer there. They had been boiled and frozen, and in one way or another destroyed or driven away. Now they could not get back. Every stream had its cañon, and in each cañon was a waterfall so high that no trout could leap up. Although they used to try it every day, not one ever succeeded.

So it went on. A great many things happened in other parts of the world. America had been discovered, and the colonies were feeling their way toward the Pacific Ocean. And in the vanguard was the famous expedition of Lewis and Clark, which went overland to the mouth of the river 
Columbia. John Colter was a hunter in this expedition. By some chance he went across the mountains on the old trail of the Nez Percés Indians, which leads across the Divide from the Missouri waters to those of the Columbia. When he came back from the Nez Percés trail, he told most wonderful tales of what he had seen at the head of the Missouri. There were cataracts of scalding water which shot straight up into the air; there were blue ponds hot enough to boil fish; there were springs that came up snorting and steaming, and which would turn trees into stone; the woods were full of holes from which issued streams of sulphur; there were cañons of untold depth, with walls of ashes full of holes which let off steam like a locomotive, and there were springs which looked peaceful enough, but which at times would burst like a bomb.

Every one laughed at Colter and his yarns, and this place where all lies were true was familiarly known as "Colter's Hell." But for once John Colter told the truth, and the truth could not easily be exaggerated. But no one believed him. When others who afterward followed him over the Nez Percés trail told the same stories, people said they had been up to "Colter's Hell" and had learned to lie.

But, as time passed, other men told what they had seen, until, in I870, a sort of official survey was made under the lead of Washburne and Doane. This party got the general bearings of the region, named many of the mountains, and found so much of interest that the next year Dr. Hayden, the 
United States Geologist, sent out a party for systematic exploration. The Hayden party came up from Colorado on horseback, through dense and tangled forests, across mountain torrents, and over craggy peaks. The story of this expedition has been most charmingly told by its youngest member, another John Coulter. Professor Coulter was the botanist of the survey, and he won the first of his many laurels on this expedition. In 1872 , acting on Hayden's report, Congress took the matter in hand, and set apart this whole region as a "public park or pleasuring ground for the benefit and enjoyment of the people," and such it remains to this day.

But while only of late this region has had a public history, the long-forgotten years between the Glacial period and the expedition of Lewis and Clark were not without interest in the history of the trout. For all these years the fishes have been trying to mount the waterfalls in order to ascend to the plateau above. Year after year, as the spawning-time came on, they leaped against the falls of the Gardiner, the Gibbon, and the Firehole Rivers, but only to fall back impotent in the pools at their bases. But the mightiest cataract of all, the great falls of the Yellowstone, they finally conquered; and in this way it was done, - not by the trout of the Yellowstone River, but by their brothers on the other side of the Divide. These followed up the Columbia to the headwaters of the Snake River, its great tributary, past the beautiful Heart Lake, and then on to the stream now called Pacific Creek, which rises on the very crest of the 
Divide. In the space ${ }^{1}$ between this stream, which flows west to help form the Snake River, and a smaller stream now called Atlantic Creek, flowing down the east slope of the Divide, the great chain of the Rocky Mountains shrinks to a narrow plateau of damp meadow, not a fourth of a mile in width; and some years, when the snows are heavy and melt late in the spring, this whole region is covered with standing water. The trout had bided their time until they found this pass, and now they were ready for action. Before the water was drained they had crossed the Divide and were descending on the Atlantic side toward the Yellowstone Lake. As the days went by, this colony of bold trout spirits grew and multiplied and filled the waters of the great clear lake, where their descendants remain to this day. And no other fishes - not the chub, nor the sucker, nor the white-fish; nor the minnow, nor the blob - had ever climbed Pacific Creek. None of them were able to follow where the trout had gone, and none of them have ever been seen in the Yellowstone Lake. What the trout had done in this lake - their victories and defeats, their struggles with the bears and pelicans, and with the terrible worm, joint enemy of trout and pelicans alike - must be left for another story.

So the trout climbed the Yellowstone Falls by way of the back staircase. Having once reached its top, it was easy to go down it on the other side. And in a similar way, by stealing over from Black-

1 For a detailed account of "Two-Ocean Pass," see Evermann, Popular Science Monthly, June, 1894. 
tail Deer Creek, they overcame the Undine Falls in Lava Creek and passed its steep obsidian walls, which not all the fishes in the world could climb.

In the Gibbon River the cataracts have proved to the trout an impassable barrier; but, strangely enough, its despised associate, the sluggish, chunky blob, a little soft-bodied, smooth, black, tadpolelike fellow, with twinkling eyes and a voracious appetite, - a fish who cannot leap at all, - has crossed this barrier. Hundreds of blob live under the stones in the upper reaches of the stream, the only fish in the Gibbon waters. There he is, and it is a standing puzzle even to himself to know how he got there. We might imagine, perhaps, that some far-off ancestor, some ancient Queen of the Blobs, was seized by an osprey and carried away in the air. Perhaps an eagle was watching and forced the osprey to give up its prey. Perhaps in the struggle the blob escaped, falling into the river above the falls, to form the beginning of the future colony. At any rate, there is the great impassable waterfall, the blob above it and below. The osprey has its nest on a broken pine-tree above the cataract, and its tyrant master, the bald eagle, watches it from some still higher crag whenever it goes fishing.

It came to pass at last that Marshall McDonald, whose duty as United States Fish Commissioner it was to look after the fishes wherever they may be, sent me to this country to see what could be done for his wards. It was a proud day when I set out from Mammoth Hot Springs astride a black cayuse, or Indian pony, which answered to the name of 
" Jump," followed by a long train of sixteen other cayuses of every variety of color and character, the most notable of all being a white pony called " Tinker." At some remote and unidentified period of her life she had bucked and killed a tradesman who bestrode her against her will, and thereby, as in the old Norse legends, she had inherited his strength, his wickedness, and his name. And when, after many adventures, I came back from this strange land and told the story of its fishes, other men were sent out from Washington with nets and buckets. They gathered up the trout and carried them to the rivers above the falls; and now all the brooks and pools of the old lava-bed, the fairest streams in the world, are full of their natural inhabitants.

And so to-day in the Gardiner, the Gibbon, the Nez Percé, and especially in Firehole River, and in the dark green depths of Shoshone Lake, one can find angling such as Izaak Walton never dreamed of. And it is now, more than ever before, "good luck for any man to be on the good side of the man that knows fish." 


\section{HOW THE TROUT CAME TO CALIFORNIA.}

"T $\begin{gathered}\mathrm{HE} \text { ultimate result of centuries on centuries } \\ \text { of the restlessness of individuals is seen in }\end{gathered}$ the facts of geographical distribution. Only in the most general way can the history of any species be traced ; but could we know it all, it would be as long and as eventful a story as the history of the colonization and settlement of North America by imnigrants from Europe. By the fishes each river in America has been a hundred times discovered, its colonization a hundred times attempted. In these efforts there is no co-operation. Every individual is for himself. Every struggle is a struggle of life and death. Each fish is a cannibal, and to each species each member of every other species is an alien and a savage."

In the light of this statement which I had occasion to make about ten years ago, we may try to find out how the trout $^{1}$ came to California.

1 I here use the word "trout," as it is used in England, for the black-spotted fishes of the genus Salmo which retain the teeth on the shaft of the vomer, and which inhabit the streams and lakes of regions where water is cold and clear. I distinguish the trout from the marine and anadromous salmon, on the one hand, and from the fine-scaled red-spotted charr (Salvelinus) on the other. If our Pilgrim Fathers had sailed from Cumberland or Westmoreland instead of from Devonshire, they would never have 
The trout is in California now. It is everywhere in California. There is no brook so poor that a trout cannot somewhere or sometime find a place in it. Even the driest "Arroyo Seco" has at its head somewhere a living spring, and here the trout remains until the winter rains release him. Moreover the trout was not always in California. At some time or other he came to California from the far Northwest. All this we know very well. We know it as well as we know that the sonorous Spanish names came to California from the South, or that Saxon enterprise came over the plains, across the Isthmus, and around the Horn.

The records of the trout are less perfect than the stories of the Argonauts or the annals of the Mission Fathers. But some records there are, and whatever these records tell is true as far as it goes. Let us piece these records out, joining their facts by lines of least resistance. Let us frame a history of what may have been true, and it will remain true until some one can read the records better.

The trout was born in Europe on the flanks of the glacial mountains. The salmon was its parent. The environment of landlocked lakes and glacial streams determined its character. From northern fjords and mossy brooks it spread over Siberia.

called the beautiful red-spotted charr of our New England streams a " trout." They had never seen a charr in the South of England, and had probably never even heard the name. Trout and salmon they knew well, and gave their names to the fishes of the New World that seemed most like them. There is no genuine trout in America east of the Great Plains. The Eastern Brook Trout or Speckled Trout is a Charr. No higher praise can be given to a Salmonoid than to call it a Charr. 
No one can tell the story of its migrations from one great dreary river to another in this vast region, for no one knows what it does there today. We know that Siberia is a land of trout; but the names of the kinds of trout in Siberia are bare names to-day, as they were in the days of Steller and Pallas and Krascheninnikow. From Kamchatka to Alaska across the cold Bering Sea is but a step for a fish of spirit, and this step is often made by the trout to this day. In the Kamchatka rivers the trout has changed somewhat from any of the varied forms that are known in Europe. Its scales are smaller (180 instead of I 30 in a line along its sides), and across its throat, half hidden by the branches of its lower jaw, is the $\wedge$-shaped blotch of scarlet. Such a mark is known in the North as the sign-manual of the Sioux Indian. It is the mark of the Cut-throat Trout. This Trout freely enters the sea in Alaska to-day, and has done so ever since it came to that region. Thus it passes readily from one stream to another; one colony mixing freely with another, till from end to end of the territory the trout are virtually alike. In the brooks the trout grow slowly and in the sea rapidly, but the streams are clear and the sea is cold. If food is scarce in the rivers, there is a clear passage from them to the ocean, with no alkaline basin or mud-flat to be crossed. For these reasons the trout of Alaska and Kamchatka have remained uniform in appearance. They are all alike Cutthroat Trout. A hundred and fifty years ago, the Russians in Kamchatka called them Mykiss. 
From this, in 1792, the old German compiler Johann Julius Walbaum gave them their scientific name of Salmo mykiss, and to this day and forever Salmo mykiss ${ }^{1}$ is the scientific name of the Cut-throat Trout.

Finding Alaska a good "fishing-ground," the trout spread itself through all its rivers. The conditions of cold clear water from the mountains to the sea are much the same all the way from the Yukon to Fraser's River and the Columbia and even as far south as the Umpqua and the Klamath. To all these, one after another, the Cut-throat Trout came from the North. The ocean offering easy access from the mouth of one to the mouth of another, there is very little difference to this day among the colonies inhabiting the different river basins. The Mad River and Elk River in Humboldt County, California, mark the southern. limit of the extension of the Cut-throat Trout along the west coast by processes of ordinary transfer from river to river by way of the sea.

Ascending the Columbia River, ${ }^{2}$ the trout

1 By the laws of scientific nomenclature, the oldest name of any species is its right name, all questions of which name is the best or sounds the best being disregarded. The Cut-throat Trout was called Salmo mykiss in Kamchatka by Walbaum in 1792, Salmo muikisi by Sclneider in 1801, Salmo purpuratus by Pallas in 1811 ; these specimens being all of the Mykiss of Kamchatka. It was named Salmo clarkii by Richardson in 1836 , from Columbia River specimens. A number of other names, as Salmo stellatus, brevicauda, and aurora, were applied by Dr. Charles Girard to specimens brought in by the Pacific Railroad Survey.

2 The Cut-throat Trout of the Lower Columbia and of Puget Sound cannot be distinguished from that found in Alaska. It is, however, sometimes given a separate name in science, as Salmo mykiss clarkii. 
spread itself widely in the streams of the green and moist region west of the Cascade Range and through the arid lava-strewn wildernesses which lie to the east. Each stream received its quota of trout; but as the way was open up and down the stream, the species remained essentially as it was in Alaska. Isolation or separation from the main body in some way is a prime factor in the permanence of new forms. In Waha Lake ${ }^{1}$ in Washington, a glacial lake which has now no outlet, the trout became entirely cut off from the parent stock, and a local race with shorter head and the black spots gathered on the tail was formed by the separation. In the central portion of this region, east of the Cascade Range, we find still the ancestral forms of the nascent species which have sprung from Salmo mykiss. In this region the scales are small, but the cut-throat mark is often wanting, and there are still living forms that seem to mark a perfect transition ${ }^{2}$ from Salmo mykiss to Salmo gairdneri. In the region where these forms are found, the true mykiss is nearly or quite wanting.

The trout thus came to the fountain-head of the Columbia, and its great tributaries the Snake, the Salmon, and Clark's Fork. In this Upper Snake River it has become separated, since the last lava flows, from the parent form, and it is

1 The Waha Lake Trout has received the name of Salmo mykiss bouvieri. This name was given by Major Charles Bendire, its discoverer, one good soldier naming it for another.

2 These transitional forms, abundant about Walla Walla and in the Des Chûtes River, are known as Salmo mykiss gibbsii, named for the discoverer, George Gibbs, once governor of Washington. 
called Salmo mykiss lewisi. How the lewisi crossed the Great Divide over to the headwaters of the Missouri and spread itself where it could in the Yellowstone Park, I have already twice told in my way. Dr. Barton W. Evermann of the U. S. Fish Commission has told it in a still better way, for he has himself visited the Two Ocean Pass and caught it in the very act of crossing the Divide. Just south of the Yellowstone Park is a great depression in the main divide of the Rocky Mountain chain which is reduced to a quarter of a mile of low marshy ground. East of this marsh the Atlantic Creek flows eastward into the Yellowstone. West of it, Pacific Creek finds its way into Snake River. Across the marsh the streams become entangled, and each one sends a part of its water over into the other. In the spring the marsh is largely under water, and there is no obstacle to the passage of the trout. For the greater part of the year one stream at least is open, and the trout can pass without hindrance from the Snake River to the Yellowstone, from the basin of the Columbia to that of the Missouri. ${ }^{1}$ Thus the trout came over into Yellowstone Lake and into the Yellowstone River, thence into the Missouri and its great clear affluents, the Jefferson, Madison,

1 The Trout of the Upper Missouri (and Upper Columbia) has been called Salmolewisi by Girard and Salmo carinatus by Cope. It woes not differ in any visible way from Salmo mykiss, although it is now isolated from the latter, its parent stock. Trout confined to rivers are always smaller than those of the same kind resident in lakes. Those which enter the sea grow to a still larger size. 
and Gallatin, and throughout the Missouri basin as far to the east as a decent fish can live. But these trout of the Upper Columbia are now separated by the great falls of Shoshone from those of the rest of the stream. They have retained their primitive characters.

The wash of the Bad Lands in Dakota fills the clear river with fine clay and quicksands, and in yellow water over quicksand bottom one does not look for trout. The Black Hills of South Dakota are full of clear streams, but there are no trout in them. The bad water of the main river into which these streams flow shuts off the trout from them. The fact that the trout are shut out shows that conditions have not materially changed since the trout came into the Missouri. The cataracts which fall from the lava beds in the Yellowstone Park have also excluded trout from a great number of beautiful streams, as the Gardiner, Gibbon, and Firehole Rivers, and the charming expanse of Shoshone ${ }^{1}$ and Lewis Lakes. This shows that these waterfalls were formed before the trout crossed the Divide.

From the tributaries of the Missouri or the Snake, the trout crossed in some way as yet unknown to the headwaters of the Platte, and filled all the brooklets of the Colorado Parks. From these it again overflowed into the neighboring waters of the Upper Arkansas. The fact that through all these streams of Eastern Colorado and Wyoming the trout are

1 In these streams are now trout in abundance, various species having been introduced by the U. S. Fish Commission in 1888 . 
substantially alike indicates that the date of crossing from one to the other, say from Denver to Pueblo, is comparatively recent. The runway is not however yet made out, but it probably lies between Pike's Peak and Denver, and may have been due to some glacial overflow from the South Platte into the creek called Font-qui-Bouille. The passage from the Missouri to the Platte is older, for here the trout have become perceptibly changed. The trout of the Platte ${ }^{1}$ and Arkansas is small, very green in color, with very red flesh; the spots are gathered chiefly on the tail, and the red cutthroat mark is bright.

From the Arkansas River to the Rio Grande over the Sangre de Cristo Mountains is again but a step, - a short step, but a very high one. This the trout has in some way crossed. Here again we may imagine glacial lakes now drained as the way of passage, or, still better, we may say we do not know. The transfer must have been an old one, for the trout in the Rio Grande ${ }^{2}$ is visibly different, the difference consisting in the larger scales and smaller size of the black spots. Once more across the main divide we follow the trout, from the tributaries of the Rio Grande to those of the Colorado. Here again the point of transfer is unknown, and here once more the imagination and the glaciers must fill up the gap. It is not far from Rio Chama over to the Rio San

1 The "Greenback Trout" of the Arkansas and Platte is Salmo mykiss stomias Cope.

2 The trout of the Rio Grande is Salmo mykiss spilurus Cope. Its range extends farther southward than any other known form, as far as the mountains of Chihuahua. 
Juan. In the beautiful streams of Western Colorado the trout have made thenselves at home, and their abundance here is scarcely less than in their chosen haunts in Washington and Alaska. Already the sage-brush trail which leads to Trapper's Lake and the cliffs along Eagle River is strewn with tin cans, newspapers, cigar stumps, and other debris of civilization. Splendid trout still lurk in the depths of the wild cañon "de las Animas Perdidas," above Hermosa and Durango. The trout of the Colorado River ${ }^{1}$ most resemble those of the Rio Grande, but they change a good deal with variations in surroundings. They show a tendency to orange rather than purple shades on the fins, the spots are small and largely on the tail, and the scales are smaller than in most of the others. The sides show often a red lateral band more distinct than in any other form thus far mentioned. The cut-throat mark is still clear, as in all trout east of the Cascades and the Sierra Nevada.

In the Arkansas basin, in a bend of the main divide, high above the river, lies a pair of glacial lakes, shut in by one moraine and separated by another. These are the Twin Lakes, beloved of anglers and famous for their magnificent mountainsetting. In these lakes are two kinds of trout, different in size, color, character of flesh, way of living, and choice of bait. Dr. Evermann and I visited the lake in I889. We found but one kind, the ordinary Greenback Trout of the Arkansas,

1 The trout of the Colorado Basin is Salmo mykiss plentriticus Cope. 
and went away contented with that. A much better angler, Mr. Charles J. Fisher of Leadville, was not satisfied with our conclusions, and insisted that we should go back with him. We did so, and were rewarded by many specimens of the beautiful "Yellow-fin Trout," 1 first introduced to science in I 889. This is a large trout with bright yellow fins, a yellow stripe along the sides, pale flesh, and the black spots very small and all gathered on the tail. It has not yet been found in ary other waters. It is very different in structure and aspect from the Greenback Trout which swarms with it in the Twin Lakes. It must be descended from the Colorado Trout, which inhabits the other side of the Divide. How it crossed the Saguache Mountains from the Gunnison or from the Roaring Fork, no one can now say, but that this crossing was a fact I have no reason to doubt.

At this point the "lay of the land" renders a diversion necessary. When you come overland to San Francisco by way of the Central Pacific, after you have passed Ogden an hour or so, you will notice a break in the mountains to the northward. Through this break to the Snake River the waters of the Great Salt Lake once flowed. It was not a salt lake then, and it was much larger than now. The old lake has been called Lake Bonneville. You may trace its former boundaries as terraces upon the slopes of the hills. You can see them from the car windows, looking out in almost any direction. Through this break once

1 The Yellow-fin Trout of Twin Lakes is Salmo mykiss macdonaldi Jordan \& Evermann. 
came up the trout ${ }^{1}$ from the Snake River to Utah Lake, Jordan River, Bear River, and Provo River. It came into all the sparkling streams of the Uintah and the Wahsatch which now find their end in the salt and alkali of the Great Basin. The trout in Utah Lake are large with large scales and small spots, and the spots are scattered over the body fure and aft as in the trout of the Columbia. Another offshoot from the Columbia Trout is found in the bed of the old Lake Lahontan, - a glacial lake now long since drained, in whose basin lie Pyramid Lake, Truckee River, and the great alkaline sink of the Humboldt. In Lake Tahoe, ${ }^{2}$ the most beautiful lake in all our country, the Tahoe trout appears to its best advantage. It is a big strong gamy fish, with small scales and large black spots, the spots being scattered over head and belly as well as on the tail. The Tahoe ${ }^{3}$ Trout is found

1 The trout of the Great Basin of Utah are Salmo mykiss virginalis.

2 The Trout of Lake Tahoe is Salmo mykiss henshazvi Gill \& Jordan, named for its discoverer, the well-known ornithologist. The same trout is found also in Feather River and Moquelumne Rivers, both on the west side of the Sierra Nevada. These facts of distribution were long a mystery, but it has been lately found that both were the result of artificial plants like that which has brought the California Rainbow Trout into Truckee River in competition with the "cut-throat" henshawi. Dr. Willard Platt of Prattsville, California, planted in $1884,1,000$ young trout from Truckee River in the streams of the Big Meadows of Plumas. About the same time trout were taken from the Carson River and placed in the Blue Lakes at the head of the Moquelumne, in Alpine County.

${ }^{8}$ The anglers find two kinds of trout in Lake Tahoe, - the Black Trout, or "Snipe," which reaches a small size, and the Silver Trout, which reaches splendid dimensions. The largest Silver Trout on record was taken near Tahoe City and sent in 1878 to General Grant. It weighed twenty-eight pounds. I have carefully compared 
not only in Lake Tahoe and its outlet, but in Humboldt River and in every suitable stream and lake in the Great Basin of Nevada, as its cousin virginalis is found in the Great Basin of Utah. As Lake Bonneville was drained to the north, so was Lake Lahontan to the northeast, and the great Snake River found room for all their waters. From its great resources, it stocked them all with trout, and the falling of the waters has left these trout to isolation and therefore to change.

Another of these old lake basins is that of Southeastern Oregon, the "Lake Idaho" of geologists, including Malheur, Summer, Goose, and Christmas Lakes and their tributaries. In these many lakes and streams trout doubtless occur, and these have doubtless undergone modifications. But the varieties thus formed are yet to be studied and to be named.

Coming back to the Colorado Basin, we find its trout spread far and wide in the mountain streams. Between the valley of the Colorado and that of the San Joaquin stands the great main chain of the Sierra Nevada, full of trout-brooks, made up of rocky walls which no trout can ever pass. To the southward this great wall breaks up into detached ranges now separated by Valleys of Death; fiery deserts and alkaline sinks, some of them below the level of the sea; burning wastes of cactus and a seven-pound "Silver Trout" taken at Tahoe City, with the ordinary henshawi, and find no real or permanent difference. The Silver Trout are the large ones living in the depths and spawning in the lake. The Black Trout live near shore, and spawn in the stream. The Silver Trout may sometime become differentiated, but is not yet a separate species or subspecies. 
greasewood, enlivened only by the rattle of the Sidewinder. In the glacial period this region had a different climate. Melting ice once filled the terrible deserts of Amargosa and Panamint with sweet waters. In some way or other this region may have been traversed by the trout. I once thought that from the Colorado to the Kern ${ }^{1}$ the trout must have come into California. It may be so; but if our theories follow the line of least resistance, there is an easier way. If the trout came from the Colorado to the Kern, it has in the transition lost most of the red of its cut-throat mark, but not all of it. The scales became somewhat larger, the red band on the side more distinct, and the spots extended forwards. In all these regards we come nearer to the trout of the Walla Walla region, the one we call Salmo mykiss gibbsii; and while it is possible that the Kern Trout (gilberti) came from the Colorado trout (pleuriticus), which they greatly resemble, my present impression is that they did not.

Let us try this supposition. The old mykiss stock filled the Columbia. After the lava flows had formed Shoshone and American falls, the trout of the Upper Columbia (lewisi) were shut off from the others. Perhaps the waterfall of the Cascades separated those of the Middle Columbia from those of the lower portion of the river. In any event, the gibbsii became somewhat different, losing in part its cut-throat mark, and passing into the smallscaled white-throated form we call the Steel-head,

1 The Trout of Kern River is Salmo gairdneri gilbertî Jordan, named for its discoverer, Dr. Charles H. Gilbert, who has been for twenty years my colleague in the study of our fishes. 
or Salmo gairdneri. This gairdneri we regard as a species different from Salmo mykiss. Its mouth is smaller, and the sides more red. But the fading of the cut-throat mark is the chief sign by which we may know it from its ancestors; and this must have passed away by gentle stages, for in the Kern trout and the Shasta trout - its descendants, if this supposition is true - there are still traces of the red dash, which the common Steel-head no longer shows.

Let us suppose that the descendants of the gibbsii entered the Lower Columbia when the blockade at the Cascades was worn through. They must have found the sea congenial, for with the gairdneri we find more of the migrating habit than in any of the mykiss forms. Trout who go to the sea must some time come back to the mountains, for all trout and salmon cast their eggs. in the gravel of fresh-water brooks or cold lakes. Migrating trout go up all the streams from Point Concepcion to Vancouver Island. Ocean feeding makes large trout. Ten pounds is not uncommon, and they have been known to run as high as thirty. These sea-run fishes are known as Steel-heads, or Salmon Trout, and are often taken for salmon. They are trout, nevertheless, not salmon at all. The name Steel-head, being used for no other fish, is well applied to them.

They are a good and gamy fish in their season, but are not always so when taken in the rivers. The Steel-head spawns in the winter, later than the salmon, and when taken as spent fish in February or March, it is often coarse and poor. It then 
appears in the markets as "Salmon" or "Salmon Trout." It is sold at a low price as "poor man's Salmon." But to this the anglers object. For when it first enters the streams, the Steel-head is a noble fish, and worthy of the best efforts of the fly-fisher. Besides, the young Steel-heads on their way back to the sea are not less attractive to the lover of fishes.

If we follow the Steel-head ${ }^{1}$ northward, we find that it has invaded the waters still occupied by its grandfather mykiss. It has gone into Fraser River, where its landlocked progeny have become the great white trout of the Kamloops and Kootenay Lakes, the Stit-tse ${ }^{2}$ of the Indians. This trout does not differ much from the Steel-head; but its large scales, silvery color, and sleek aspect give it an appearance different from its cut-throat ancestry, which lives with it in the same waters. Different species the two are, beyond a doubt, yet they belong to the same series. They stand at opposite ends of a long chain that still has many links, and that has lost many more. For each link in the great chain there is a long and an eventful history.

Allied to the Kamloops trout is another interesting form, - the Blueback Trout $^{3}$ of Crescent Lake and other ponds in the Olympic Mountains. This form has been only lately made known to

1 The Steel-head Trout is Salmo gairdneri Richardson, named in 1836 for its discoverer, Dr. Gairdner, an enthusiastic young naturalist, stationed at Fort Vancouver, in the employ of the Fur Company.

2 The Stit-tse Trout is Salmo gairdneri kamloofs Jordan.

8 The Blueback or Beardslee Trout of Lake Crescent is Salmo beardsleei Jordan \& Seale, named for its discoverer. 
science through the enthusiastic devotion of RearAdmiral Beardslee, who regards it as the finest of all trout, and who has taken specimens of ten pounds' weight in this wonderful lake. This form differs from the Steel-head in its large scales and large head, and is one of the best marked of all the trout-forms in the northwest.

In the same lake occurs another splendid trout of large size, the Crescent Trout. ${ }^{1}$ It seems to be also an offshoot from the Steel-head, but its head is quite different in cut and much larger in size. Its scales are considerably smaller than in the Beardslee trout, and in both the black spots are small and scattered.

If what I think to-day is the truth for to-morrow, the Steel-head passed southward from the Columbia along the California coast, entering the brooks of the Coast Range, spawning there and passing back into the sea, - but not always, for sometimes it had gone so far from the ocean that it could never get back in its lifetime, - the whole western flank of the Sierra Nevada being full of trout brooks. The trout came into them. They stayed because it was good to be there. And from Steel-head stock may have come the splendid trout of the Kern already mentioned, Salmo gairdneri gilberti. It is probably more like the original Steel-head than the Steel-head itself now is; for it has red under the throat, like its great-grandfather mykiss. In any event, it fills the Kern River now, and is ready for any angler who invades its rocky fastnesses.

1 The Crescent Trout is Sulmo crescentis Jordan \& Beardslee. 
The trout in the main Kern River grow to a large size. Others have clambered into the mountain meadows, and they are very small and very bright in color. Those separated from the rest by the falls of Agua Bonita ${ }^{1}$ in Volcano Creek, on the flanks of Mount Whitney, are now noticeably different from any other which we know. The scales are very small, and barely touch each other; the fins and bands are yellow, and not red; the cutthroat mark is yellow too, and the black spots are profusely scattered everywhere. In color like the Yellow-fin Trout of the Colorado Lakes, this Golden Trout of Mount Whitney is different in other respects; and of all the trout on record it is smallest and prettiest. From Agua Bonita anglers have taken it to the east side of Mount Whitney, and it is now found in the rivers running down into Owen's Lake.

The trout ascended the San Joaquin, sent up also side colonies not only to the Kern but to King's River, the Merced, Tuolumne, Stanislaus, Calaveras, Moquelumne, and all the other mountain tributaries. What changes took place in these streams we do not know, for it will take a long time to go a-fishing in them all. There is enough yet to be found out in the Sierra Nevada to interest ichthyologists and anglers alike for many future generations.

The San Joaquin meets the Sacramento end to end, and the two break through the Coast Range to the sea. In the Upper Sacramento is occasion-

1 The Golden Trout of Mount Whitney is Salmo gairdneri agrua bonita Jordan. 
ally taken a trout which the Indians call No-Shee, ${ }^{1}$ or Nissuee, and which must resemble the original stock of the San Joaquin even more closely than the Kern trout does. It has the small scales of the Kern River fish, but the red cut-throat mark is gone, and the spots are few and sparse. It is a large trout, and is but rarely taken, the specimens now known being from the McCloud.

The common trout of the Upper Sacramento may be descended from this; but its scales are larger, its body deeper, the red band on the sides more distinct, and there is at least a trace of the cut-throat mark, showing where its tribe came from. This trout is the one distributed from the hatchery at Baird as the California Rainbow Trout, $^{2}$ and planted, often ineffectively, in many Eastern rivers, - ineffectively, I say, because of its bad habit of dropping down with the current and losing itself in unwholesome waters on its way to the sea. The true Rainbow Trout is, however, somewhat different. That name belongs to the common trout of the Coast Range; smaller, with large scales, white throat, and varying much with streams and food. The large scales seem to mark a change on which we make, provisionally, a division of species. The little trout of the Coast Range $^{3}$ is likewise an offshoot of the Steel-head.

1 The No-Shee Trout is Salmo gairdneri stonei Jordan, named for its discoverer Livingston Stone, the veteran fish-culturist of the U.S. Hatchery at Baird, California.

2 The Rainbow Trout of the Upper Sacramento is Salmo gairdneri shasta Jordan.

3 The Trout of the Coast Range is Salmo irideus Gibbons; the type locality of the species being San Leandro Creek, in Alameda County. 
For all we know it is constantly receiving accessions from the small Steel-heads which do not find their way to the sea. It is not always easy to tell where Steel-head trout leaves off and Brook trout begins. The Rainbow Trout occurs in the coastwise brooks all the way from Oregon to the Mexican line. It abounds in Rio San Luis Rey, in San Diego County, and I have heard of its occurrence across the border in Mexico. In no two streams does this Coast Range trout seem to be exactly the same, and in all it is small, speckled, and vigorous. In one stream of the Redwood country, Purisima Creek, in San Mateo County, there is a high waterfall where it drops into the sea. No trout can climb this fall, and those who are above it have been there for many generations. These Purisima Trout, befitting their name, are the brightest in color of all the trout of the mountains. When the trout which have gone down over the Purisima falls reappear in other streams, as they often do, we can still know them by the brightness of their colors.

Northward the Brook Trout, or Rainbow Trout, grows more distinct from its relatives. Its colors in Oregon and Washington are more marked, its scales larger, its mouth smaller. About the mouth of the Columbia it becomes the form known as Salmo iridens masoni. Here no one could fail to distinguish it from the Steel-head. The Steel-head, Cut-throat, and Rainbow are all found here, three different generations of trout, each with a long history. Here each one is a distinct "species," beyond all doubt or question. It is equally 
true that in other regions these species lose their distinctness. In the Upper Columbia, Steel-head and Cut-throat seem hopelessly entangled, as in California the Steel-head is confused with the Rainbow Trout. From the standpoint of the evolutionist this is delightful, while it breaks up every system or scheme of the systematic naturalist. But the angler likes it well enough; and to him, whether there be one species or three, one variety or twenty, - all are equally delightful. And whatever the difficulties, one who writes on the trout of California does not willingly drop his pen at the end of his theme. The most charming of fishes, the most beautiful of lands, - when the two are brought together, one wishes to say of them something better than has yet been said. It is with regret that he lays down the pen in confession of inability to say it.

The habitat of each of the forms of trout is indicated in the following list:-

\section{Cut-thrót Trout: Salmo mykiss.}

mykiss . Alaska.

clarki. - Washington and Oregon, chiefly west of the Cascades.

bouvieri. "Waha Lake.

lewisi . Snake River, above the Falls and Upper Missouri.

stomias . Upper Platte and Arkansas.

spilurus . . Rio Grande.

pleuriticus . Rio Colorado.

macdonaldi Twin Lakes.

virginalis . Lake Bonneville.

henshawi . Lake Lahontan.

?_- . Lake Idaho. 
gibbsii - Columbia Basin, from Shoshone Falls to Cascades.

Steel-head Trout: Salmo gairdneri.

gairdneri - Coastwise streams, from Puget Sound to Pt. Sur.

kamloops . Lakes of Upper Columbia and Fraser River-

beardsleei . Lake Crescent.

crescentis . Lake Crescent.

stonei . . Upper Sacramento.

shasta . Upper Sacramento.

gilberti . . Kern River, etc.

agua-bonita Volcano Creek, etc.

Rainbow Trout : Salmo irideus.

irideus . . Coast Range brooks in Californis masoni . Coast Range brooks in Oremon.

The following very hypothetical diagra nows their relationships :-
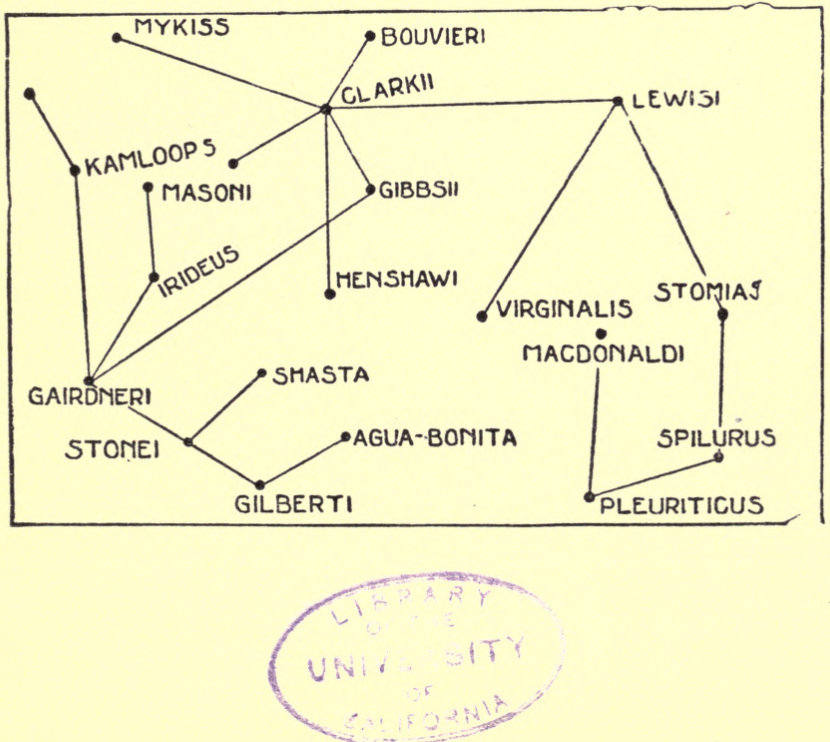



THIS BOOK IS DUE ON THE IAST DATE
STAMPED BELOW

AN INITIAL FINE OF 25 CENTS WILL BE ASSESSED FOR FAILURE TO RETURN THIS BOOK ON THE DATE DUE ON THE FOURTH WILL INCREASE TO 50 CENTS SEVENTH DAY DAY AND TO $\$ 1.00$ ON THE OVERDUE.

OCT $41932: 29 \mathrm{Sep} 56 \mathrm{CR}$

RAY 91933

RETURPED: SEP 261956 TO BIO.LIBE.

JUN 191934

1. de'60CT

DEC 111940 MAY 241960

MAY 251960

OCT $I_{4} 1946$

MAR 211947

$\equiv 20 \operatorname{Mar}^{\prime} 49 B G$

LD $21-50 m-8,32$ 
YB 12567

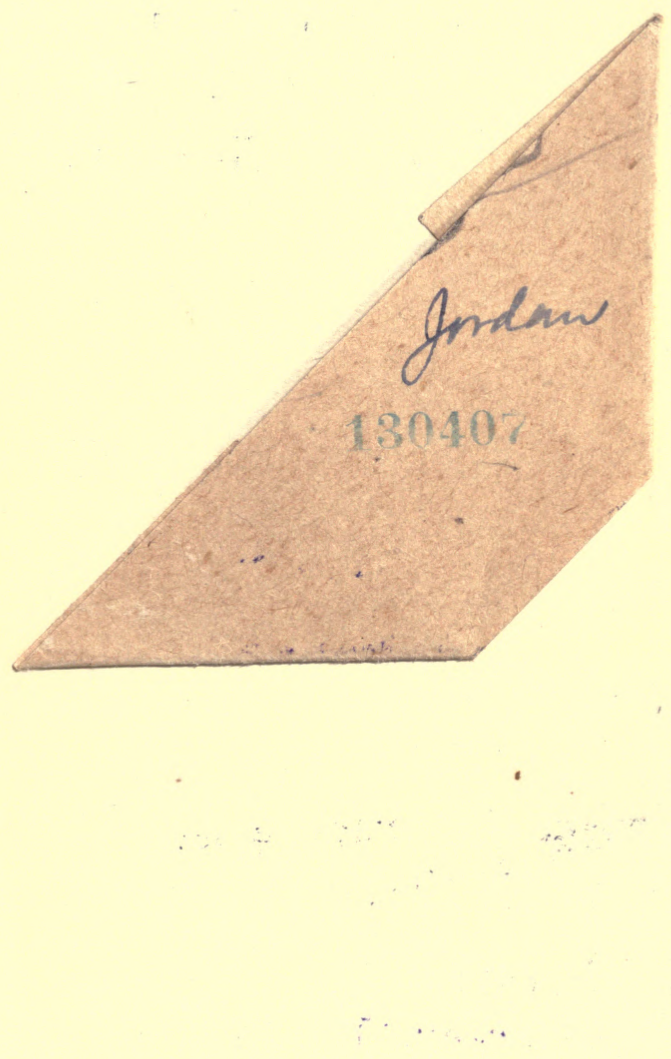


